Universidade de São Paulo

Escola Superior de Agricultura "Luiz de Queiroz"

Morfogênese do bacterioma e multiplicação de simbiontes ao longo do desenvolvimento de Diaphorina citri (Hemiptera: Liviidae) e sua resposta ao estresse térmico

Fábio Cleisto Alda Dossi

Tese apresentada para obtenção do título de Doutor em Ciências. Área de concentração: Entomologia

Piracicaba

2013 
Fábio Cleisto Alda Dossi

Biólogo

Morfogênese do bacterioma e multiplicação de simbiontes ao longo do desenvolvimento de Diaphorina citri (Hemiptera: Liviidae) e sua resposta ao estresse térmico

versão revisada de acordo com a resolução CoPGr 6018 de 2011

Orientador:

Prof. Dr. FERNANDO LUIS CÔNSOLI

Tese apresentada para obtenção do título de Doutor em Ciências. Área de concentração: Entomologia 
Dados Internacionais de Catalogação na Publicação DIVISÃO DE BIBLIOTECA - DIBD/ESALQ/USP

\section{Dossi, Fábio Cleisto Alda}

Morfogênese do bacterioma e multiplicação de simbiontes ao longo do desenvolvimento de Diaphorina citri (Hemiptera: Liviidae) e sua resposta ao estresse térmico / Fábio Cleisto Alda Dossi.- - versão revisada de acordo com a resolução CoPGr 6018 de 2011. - - Piracicaba, 2013.

99 p: il.

Tese (Doutorado) - - Escola Superior de Agricultura "Luiz de Queiroz", 2013.

1. Bacterioma 2. Choque térmico 3. Densidade de simbiontes 4. Embriogênese I. Título

CDD 632.75

D724m

"Permitida a cópia total ou parcial deste documento, desde que citada a fonte - 0 autor" 
A Deus, sempre presente.

AGRADEÇO

Aos meus queridos pais Abílio e Gilda, e ao meu irmão Sandro, pelo afeto, incentivo, e ensinamentos fundamentais em minha formação pessoal e profissional.

À minha noiva Gislaine, pelo companheirismo e apoio valiosos.

DEDICO E AGRADEÇO 


\section{AGRADECIMENTOS}

Ao Prof. Dr. Fernando L. Cônsoli pela orientação, amizade, ensinamentos, confiança e oportunidade para a realização desse trabalho.

Ao Conselho Nacional de Desenvolvimento Científico e Tecnológico (CNPq) pela concessão de bolsa de estudo.

À todos os professores do Programa de Pós-Graduação em Entomologia da Escola Superior de Agricultura "Luiz de Queiroz" (ESALQ/USP), pelo aprendizado.

Aos amigos do Laboratório de Interações em Insetos (ESALQ/USP), Adrian Sosa Gomez, Aline Guidolin, Aline Peruchi, Daniel Russ, Ellen Andrade, Felipe Domingues, Guilherme Rossi, Ligia Arruda, Luis Gustavo Almeida, Karina Lucas, Pablo Fresia e Priscila Fortes, pelo companheirismo, amizade, aprendizado e auxílio prestados durante a realização deste trabalho.

Aos amigos do Laboratório de Biologia de Insetos (ESALQ/USP), em especial aos amigos Alexandre Diniz, Leandro Geremias, Gustavo Alves e Jaci Mendes, pela amizade e apoio prestados.

Aos amigos do Laboratório de Biologia Molecular de Plantas (ESALQ/USP), especialmente Thais Souza, Rafael Colombi, Flávia Franco, Poliene Costa, Ligia Macedo, Larissa Spoladore e Aline Borges, pelo companheirismo e apoio prestados.

Aos amigos do Laboratório de Anatomia Vegetal (ESALQ/USP), em especial à técnica Marli Soares pelo auxílio prestado.

À Profa. Yuval Gottlieb-Dror da 'Koret School of Veterinary Medicine' da 'The Hebrew University of Jerusalem', pelo apoio prestado durante a realização de parte deste trabalho.

Ao amigo Dr. Edney Pereira da Silva da Faculdade de Ciências Agrárias e Veterinárias da Universidade Estadual Paulista "Júlio de Mesquita Filho" - FCAV/UNESP, pelo auxílio nas análises estatísticas.

A todos aqueles que contribuíram direta ou indiretamente para a realização desse trabalho, meus sinceros agradecimentos. 


\section{SUMÁRIO}

RESUMO … -

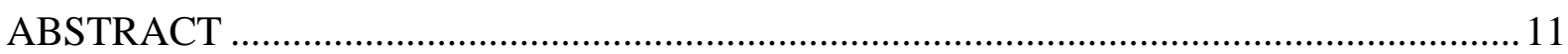

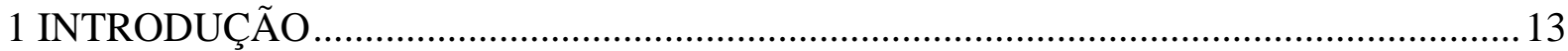

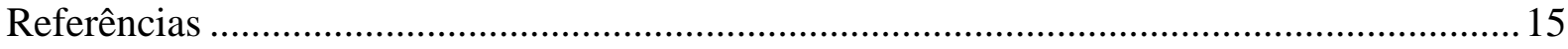

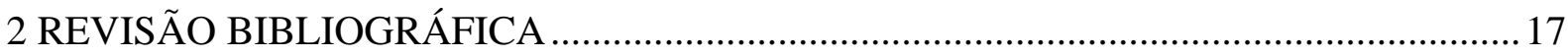

2.1 Aspectos comportamentais e importância econômica de Diaphorina citri............................ 17

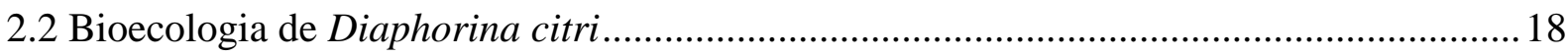

2.3 Interações endocitobiontes - sugadores de seiva ............................................................ 19

2.4 Desenvolvimento embrionário e formação de estruturas que abrigam simbiontes .............20

2.5 Efeitos do estresse térmico sobre a densidade de simbiontes e a estabilidade da associação

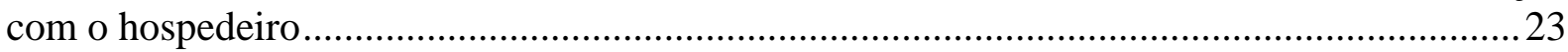

2.6 Estabelecimento de simbiontes durante a embriogênese....................................................24

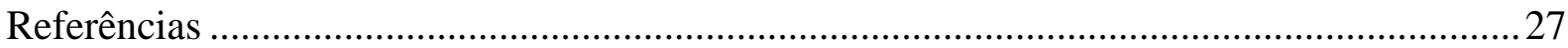

3 MORFOGÊNESE DO BACTERIOMA DURANTE O DESENVOLVIMENTO EMBRIONÁRIO DE Diaphorina citri (HEMIPTERA, LIVIIDAE) ........................................35

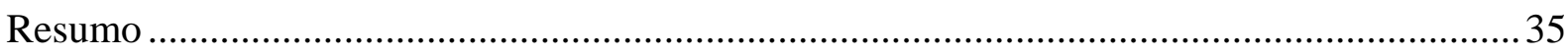

Abstract.

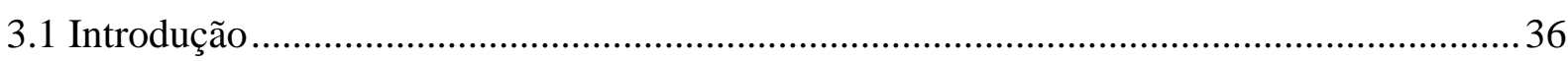

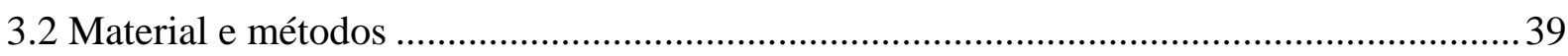

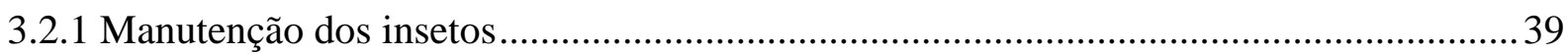

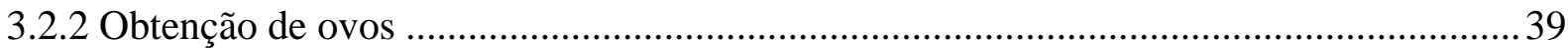

3.2.3 Preparação de embriões para análise em montagem total .................................................40

3.2.4 Preparação de ovos embrionados para análise histológica.................................................40

3.2.5 Processamento de amostras para hibridação in situ e análise por microscopia de fluorescência (FISH) ............................................................................................. 41

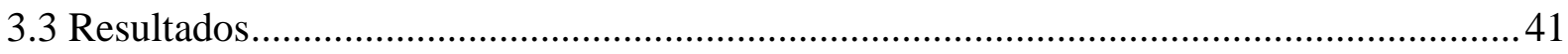

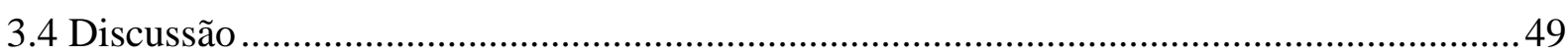

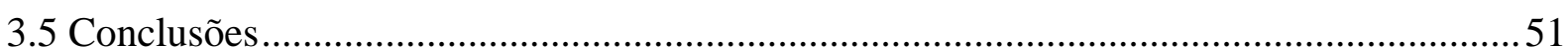

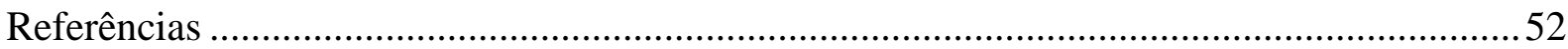

4 DENSIDADE DE ENDOSSIMBIONTES DURANTE O DESENVOLVIMENTO BIOLÓGICO DE Diaphorina citri (HEMIPTERA; LIVIIDAE) ………………………….....57

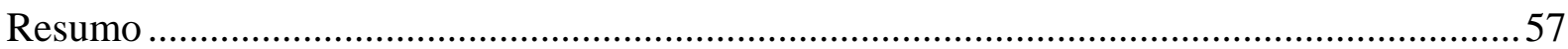

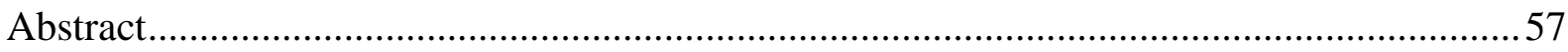

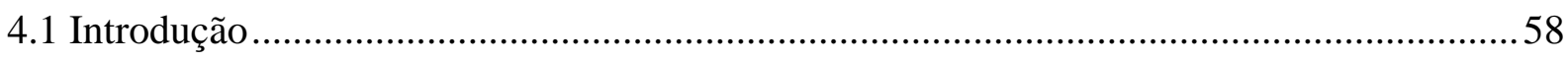

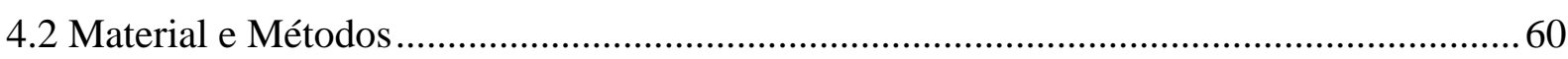

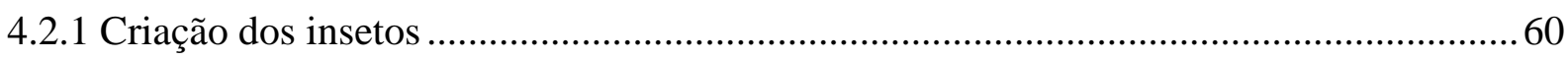




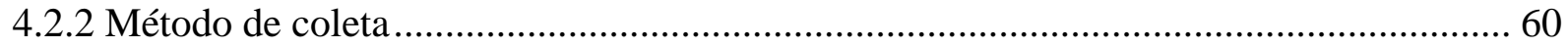

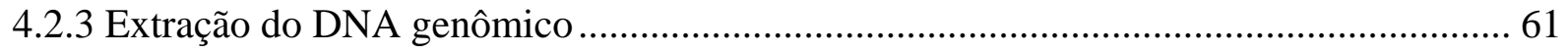

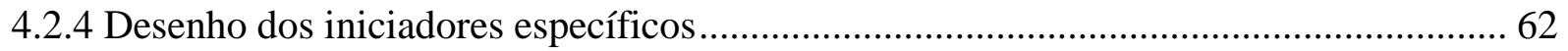

4.2.5 Clonagem, curva padrão e condições das reações de PCR quantitativo em tempo real . 62

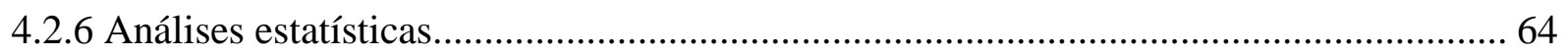

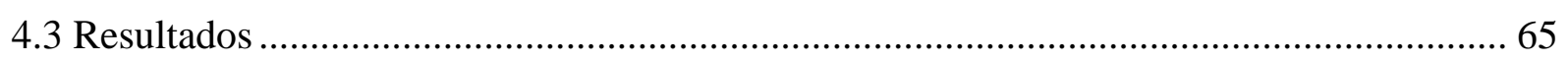

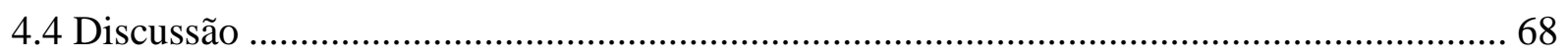

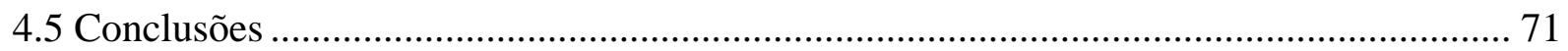

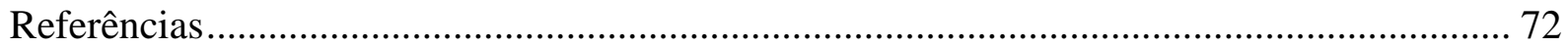

5 CRESCIMENTO DE SIMBIONTES EM Diaphorina citri (HEMIPTERA; LIVIIDAE) EM

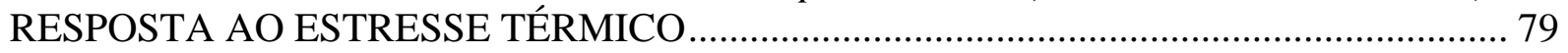

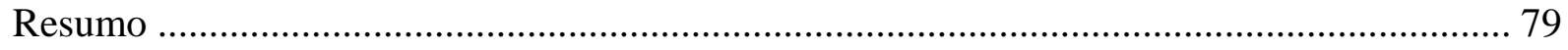

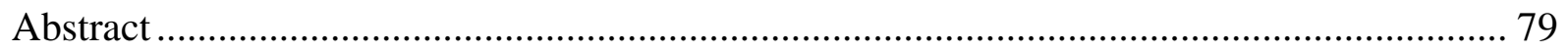

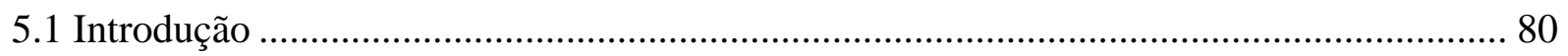

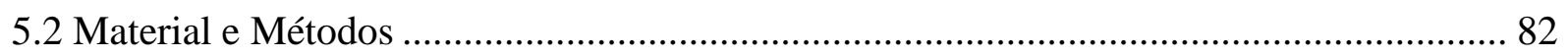

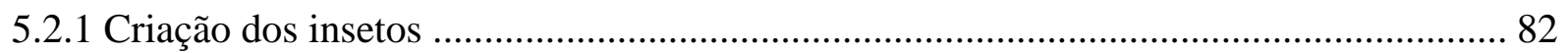

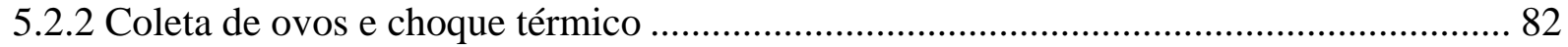

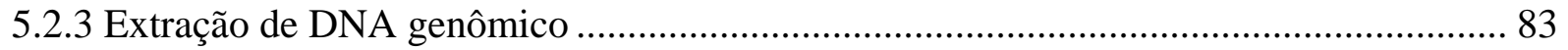

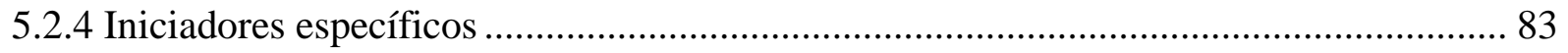

5.2.5 Clonagem e otimização das condições de reação de PCR quantitativo .......................... 84

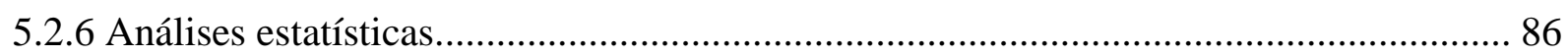

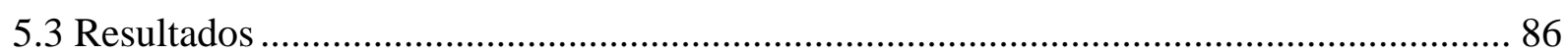

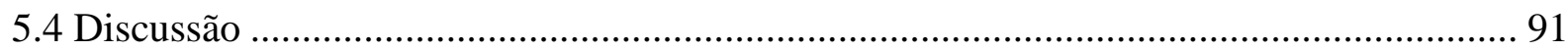

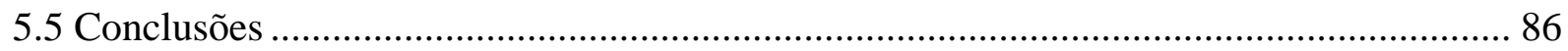

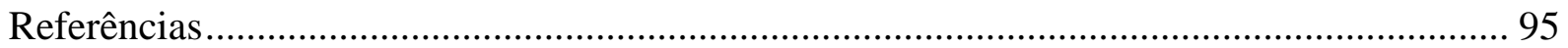




\section{RESUMO}

\section{Morfogênese do bacterioma e multiplicação de simbiontes ao longo do desenvolvimento de Diaphorina citri (Hemiptera: Liviidae) e sua resposta ao estresse térmico}

Diaphorina citri depende dos endossimbiontes presentes em seu bacterioma, as bactérias Carsonella e Profftella, para o fornecimento de nutrientes essenciais ao seu desenvolvimento. D. citri também está associada à bactéria Wolbachia, que infecta inúmeros tecidos desse inseto, incluindo seu bacterioma. Esses simbiontes são transmitidos verticalmente, sendo incorporados ao bacterioma. Neste estudo, são abordados os eventos relacionados à formação do bacterioma, à dinâmica da densidade dos simbiontes durante o ciclo biológico do hospedeiro e à sensibilidade dos simbiontes ao estresse térmico. A morfogênese do bacterioma durante a embriogênese de $D$. citri foi descrita por meio de histologia e marcação com sondas oligonucleotídicas fluorescentes (FISH) específicas para os simbiontes do bacterioma. No início da embriogênese, as bactérias permanecem agrupadas em uma massa no polo posterior do ovo. Vitelófagos se aderem à massa de simbiontes no início da blastulação, precedendo à formação dos bacteriócitos. O bacterioma transitório resultante possui bacteriócitos que contém o simbionte do sincício (Profftella), localizado externamente aos que contém o simbionte do bacteriócito (Carsonella). Na sequência do desenvolvimento, ocorre a reorganização dos bacteriócitos, evento seguido pela formação da região sincicial. $\mathrm{O}$ bacterioma é movido para a região abdominal do embrião durante a catatrepsis, passando ao formato trilobado típico ao final da embriogênese. A densidade dos simbiontes associados ao psílideo dos citros durante o seu desenvolvimento foi determinada por PCR quantitativo em tempo real (qPCR). A densidade dos diferentes simbiontes, dada pela análise do número de cópias dos genes 16S rRNA (Carsonella e Profftella) e ftsZ (Wolbachia), revelaram o crescimento contínuo dos simbiontes ao longo do desenvolvimento do hospedeiro. As curvas e taxas de crescimento dos simbiontes, estimadas por meio da equação de Gompertz, indicaram relação inversamente proporcional à especificidade das relações simbiontehospedeiro e o tempo para atingir a taxa máxima de crescimento. A densidade de Carsonella foi significativamente menor daquela de Profftella em todos os estágios analisados, apesar da tendência de aumento paralelo. As taxas de crescimento de Wolbachia foram similares às de Carsonella, mas a densidade foi inferior. Nos adultos, a densidade dos três simbiontes foi maior nos machos. Entretanto, esses simbiontes continuaram a apresentar crescimento em fêmeas em atividade de oviposição, mesmo com a sua incorporação aos oócitos, o que diverge da diminuição normalmente observada em outros sistemas. Os simbiontes de D. citri responderam de forma variável ao estresse térmico. Os diferentes simbiontes apresentaram resposta própria aos diversos períodos de exposição às diferentes condições térmicas de estresse. Ainda, foi detectada a influência de um simbionte na capacidade de resposta do outro, demonstrando a existência de mecanismos de comunicação e regulação entre os simbiontes de $D$. citri. O estudo demonstra a influência do estresse térmico sobre a densidade dos simbiontes e a necessidade de se compreender melhor a biologia das interações insetosimbiontes e a dinâmica das relações com o ambiente.

Palavras-chave: Bacterioma; Choque térmico; Densidade de simbiontes; Embriogênese 


\begin{abstract}
Bacteriome morphogenesis and symbiont growth during development of Diaphorina citri (Hemiptera: Liviidae), and its response to heat stress
\end{abstract}

Diaphorina citri feeds on phloem-sap and depends on bacterial symbionts harbored in the bacteriome as a supplementary source of nutrients lacking in the diet. These bacteria are vertically transmitted, being incorporated into the developing bacteriome. Here, we focus on the events related to bacteriome morphogenesis, symbiont density during host development and the effects of exposure to high temperatures on the establishment of endosymbionts during immature development. The bacteriome morphogenesis during D. citri embryogenesis was investigated by means of histology and fluorescence in situ hybridization analysis (FISH) using symbiont-specific oligonucleotide probes. During early embryogenesis, the bacteria remain aggregated in a symbiont-ball at the posterior pole of the egg. Vitellophages adhere to the symbiont mass during early blastulation, preceding bacteriocyte formation. As a result, the transient bacteriome has the bacteriocytes that harbors the syncytium symbiont (Profftella) arranged externally to those harboring Carsonella. The bacteriome is moved to the embryo abdominal region as a result of katatrepsis, becoming trilobated during the later embryonic development. The infection density of the endosymbionts associated to the Asian citrus psyllid was determined using real-time quantitative PCR (qPCR), throughout the host life cycle. Copy number of genes $16 \mathrm{~S}$ rRNA (Carsonella and Profftella) and ftsZ (Wolbachia), revealed the continuous growth of symbionts during host development. Growth curves and rates of symbionts estimated using the Gompertz equation indicated an inversely proportional correlation between the degree of symbiont cospeciation with the host and the time to achieve the maximum growth rate. Carsonella density was significantly lower than that of Profftella at all stages analyzed, despite their joint growth trend. The growth rates of Wolbachia were similar to those of Carsonella, but Wolbachia had a lower density. In adults, the density of the three symbionts was higher in males. However, density in reproductive females remained high, despite the incorporation of symbionts in the oocytes. The increased density of symbionts in postreproductive adults contrasts with the decrease observed in other symbiotic systems. The infection density is mutually related to biological effects, but the symbiont may vary the response to heat stress. Density of Profftella and Carsonella was higher than that of Wolbachia, although there were different response patterns related to temperatures and treatment times. Symbionts associated with D. citri have their growth affected by the symbionts. This study demonstrates the effects of the heat shock on symbiont density during nymphal development and illustrates the need of further work the biology of insect-symbiont interactions and the dynamics of its relationships with the environment for a better understading of such associations.

Keywords: Bacteriome; Embryogenesis; Heat shock; Symbiont density 


\section{INTRODUÇÃO}

Diaphorina citri Kuwayama (Hemiptera: Liviidae), a exemplo de outros insetos sugadores de seiva em Sternorrhyncha (BUCHNER, 1965; BAUMANN, 2005), mantêm associações obrigatórias de simbiose com micro-organismos que podem se alojar em estruturas celulares específicas (bacteriócitos), contidas na hemocele do hospedeiro. Os bacteriócitos podem ocorrer de forma isolada, dispersos na hemocele ou aderidos a outros tecidos, ou formando estruturas complexas, sendo denominados bacterioma ou micetoma (DOUGLAS, 1998; BAUMANN, 2005). O bacterioma típico é constituído por três tipos celulares, sendo formado internamente por uma área multinucleada central de aspecto sincicial, a qual é circundada por bacteriócitos uninucleados. A estrutura do bacterioma é finalizada por um envelope de células achatadas que envolve todo o órgão (BAUMANN, 2005). O citoplasma dos bacteriócitos contém bactérias pleomórficas Gram-negativas, denominadas simbionte primário, o qual é transmitido verticalmente à progênie via aparelho reprodutor. No sincício do bacterioma ocorrem bactérias morfologicamente distintas, o simbionte Profftella, inicialmente referido como sendo um simbionte secundário (SUBANDIYAH et al., 2000; BAUMANN, 2005), são, na verdade, bactérias que complementam a atividade metabólica de Carsonella, tendo assim, papel fundamental no metabolismo do hospedeiro (SLOAN; MORAN, 2012).

O bacterioma de D. citri é revestido por uma camada de bacteriócitos, não havendo um epitélio de revestimento propriamente dito. Durante o processo de oogênese, bacteriócitos contendo endossimbiontes desprendem-se do bacterioma e migram até os ovaríolos, invadindo o oócito em desenvolvimento e liberando os simbiontes que ganham acesso ao citoplasma do oócito (DOSSI, 2008). O mecanismo empreendido na transmissão transovariana de endossimbiontes aos oócitos apresenta característiscas que se assemelham as de diferentes espécies de insetos, podendo ocorrer na oogênese inicial (SACCHI et al., 2008), durante a vitelogênese (SZKLARZEWICZ; MOSKAL, 2001), ou tardiamente, durante a coriogênese (SZKLARZEWICZ; KEDRA; NIZNIK, 2006). Salvo as peculiaridades de cada espécie, os micro-organismos simbiontes distribuem-se em regiões do ovo próximas àquela onde teve acesso durante o período de infecção do oócito, sendo transferidos ao(s) tecido(s) especializado(s) durante a embriogênese (BUCHNER, 1965; LAUDANI et al., 1995; MIURA et al., 2003; SWIATONIOWSKA et al., 2012).

Segundo Wilkinson et al. (2003), os simbiontes de embriões partenogenéticos de Acyrthosiphum pisum (Hemiptera: Aphididae) são provenientes de apenas um bacteriócito 
materno, sugerindo que apenas parte da população de simbiontes do bacteriócito seja incorporada a cada embrião. Miura et al. (2003) verificaram a existência de comportamentos distintos de transmissão de simbiontes em embriões sexuados e partenogenéticos. Nestes últimos, a transferência de simbiontes do bacteriócito materno para o embrião em estágio de blástula ocorre por exo- e/ou endocitose (KOGA et al., 2012). A internalização de microorganismos simbiontes e o comportamento dos complexos intradeutoplasmáticos, isto é, a associação entre vitelófagos e simbiontes, parece ser muito variável até mesmo entre espécies filogeneticamente próximas. Este processo parece ser dependente da organização inicial dos simbiontes no ovo após a sua transferência via ovário, o momento infectivo durante a embriogênese (infecção original das células do hospedeiro que darão origem ao bacterioma), e a forma de movimentação no deutoplasma, se direta ou indiretamente dependentes dos tecidos embrionários (BUCHNER, 1965; LAUDANI et al., 1995; MIURA et al., 2003).

A existência de mecanismos de controle de crescimento populacional de simbiontes durante o período embrionário, foi sugerida por Miura et al. (2003) em A. pisum como consequência da barreira imposta por filamentos de actina em torno da massa de simbiontes. Adicionalmente, há evidências da produção e liberação de substâncias com ação antibacteriana em tecidos extraembrionários e no deutoplasma de ovos de Manduca sexta (Lepidoptera: Sphingidae) (GORMAN; KANKANALA; KANOST, 2004; ABDEL-LATIEF; HILKER, 2008). A existência de mecanismos de defesa no embrião de D. citri é ainda desconhecida, mas sabe-se que os simbiontes associados a este inseto se agregam ao final do processo de infecção do oócito, junto ao pólo posterior, formando uma massa de simbiontes (DOSSI, 2008), podendo se constituir em mecanismo conjunto para se desvencilhar do sistema imunológico do hospedeiro.

Em face à importância da interação $D$. citri-simbiontes e da inexistência de relatos acerca dos mecanismos envolvidos na formação de estruturas responsáveis por abrigar simbiontes nesse sistema, o presente trabalho visa caracterizar a distribuição no ovo, dos simbiontes Carsonella (abrigado nos bacteriócitos) e Profftella (associado ao sincício) (NAKABACHI et al., 2013), durante o desenvolvimento embrionário, avaliar a multiplicação de simbiontes no decorrer do desenvolvimento das formas imaturas do hospedeiro, e estudar o efeito do estresse térmico (choque térmico) na manutenção dos simbiontes durante o desenvolvimento imaturo. Tais informações poderão fundamentar estudos futuros aplicados ao desenvolvimento de estratégias de manejo desse inseto. 


\section{Referências}

ABDEL-LATIEF, M.; HILKER, M. Innate immunity: eggs of Manduca sexta are able to respond to parasitism by Trichogramma evanescens. Insect Biochemistry and Molecular Biology, Oxford, v. 38, n. 2, p. 136-145, 2008.

BAUMANN, P. Biology bacteriocyte-associated endosymbionts of plant sap-sucking insects. Annual Review of Microbiology, Palo Alto, v. 59, p. 155-189, 2005.

BUCHNER, P. Endosymbiosis of animals with plant microorganisms. New York: John Wiley, 1965. 909 p.

DOSSI, F.C.A. Ultraestrutura do aparelho reprodutor feminino e mecanismos de transmissão transovariana de endossimbiontes de Diaphorina citri Kuwayama, 1908 (Hemiptera: Psyllidae). 2008. Dissertação (Mestrado em Entomologia) - Escola Superior de Agricultura Luiz de Queiroz, Universidade de São Paulo, Piracicaba, 2009. Disponível em: <http://www.teses.usp.br/teses/disponiveis/11/11146/tde-10022009-095926/>. Acesso em: 29-05-2013.

DOUGLAS, A.E. Nutritional interactions in insect-microbial symbioses: aphids and their symbiotic bacteria Buchnera. Annual Review of Entomology, Palo Alto, v.43, p. 17-37, 1998.

GORMAN, M.J.; KANKANALA, P.; KANOST, M.R. Bacterial challenge stimulates innate immune responses in extra-embryonic tissues of tobacco hornworm eggs. Insect Biochemistry and Molecular Biology, Oxford, v. 13, n. 1, p. 19-24, 2004.

KOGA, R.; MENG, X.Y.; TUSUCHIDA, T.; FUKATSU, T. Cellular mechanism for selective vertical transmission of an obligate insect symbiont at the bacteriocyte-embryo interface. Proceedings of the National Academy of Sciences of the United States of America, Washington, v. 109, n. 20, p. 1230-1237, 2012.

LAUDANI, U.; GRIGOLO, A.; SACCHI, L.; CORONA, S.; BISCALDI, G. On the mycetome formation in Periplaneta americana (Blattaria, Blattidae). Italian Journal of Zoology, Padova, v. 62, n. 4, p. 345-351, 1995.

MIURA, T.; BRAENDLE, C.; SHINGLETON, A.; SISK, G.; KAMBLAMPATI, S.; STERN, D.L. A comparison of parthenogenetic and sexual embryogenesis of the pea aphid Acyrthosiphon pisum (Hemiptera: Aphidoidea). Journal of Experimental Zoology Part B: Molecular and Developmental Evolution, Washington, v. 295, n. 1, p. 59-81, 2003.

NAKABACHI, A.; UEOKA, R.; OSHIMA, K.; TETA, R.; MANGONI, A.; GURGUI, M.; OLDHAM, N.J.; van ECHTEN-DECKERT, G.; OKAMURA, K.; YAMAMOTO, K.; INOUE, H.; OHKUMA, M.; HONGOH, Y.; MIYAGISHIMA, S.; HATTORI, M.; PIEL, J.; FUKATSU, T. Defensive bacteriome symbiont with a drastically reduced genome. Current Biology, Cambridge, v. 23, n. 15, p. 1478-1484, 2013.

SACCHI, L.; GENCHI, M.; CLEMENTI, E.; BIGLIARDI, E.; AVANZATI, A.M.; PAJORO, M.; NEGRI, I.; MARZORATI, M.; GONELLA, E.; ALMA, A.; DAFFONCHIO, D.; BANDI, C. Multiple symbiosis in the leafhopper Scaphoideus titanus (Hemiptera: 
Cicadellidae): details of transovarial transmission of Cardinium sp. and yeast-like endosymbionts. Tissue \& Cell, Edinburgh, v. 40, n. 4, p. 231-242, 2008.

SUBANDIYAH, S.; NIKOH, N.; TSUYUMU, S.; SOMOWIYARJO, S.; FUKATSU, T. Complex endosymbiotic microbiota of the citrus psyllid Diaphorina citri (Homoptera: Psylloidea). Zoological Science, Tokyo, v. 17, n. 7, p. 983-989, 2000.

SWIATONIOWSKA, M.; OGORZALEK, A.; GOLAS, A.; MICHALIK, A.; SZKLARZEWICZ, T. Ultrastructure, distribution, and transovarial transmission of symbiotic microorganisms in Nysius ericae and Nithecus jacobaeae (Heteroptera: Lygaeidae:

Orsillinae). Protoplasma, Viena, v. 250, n. 1, p. 325-332, 2012.

SZKLARZEWICZ, T.; MOSKAL, A. Ultrastructure, distribution, and transmission of endosymbionts in the whitefly Aleurochiton aceris Modeer (Insecta, Hemiptera, Aleyrodinea). Protoplasma, Viena, v. 218, n. 1, p. 45-53, 2001.

SZKLARZEWICZ, T.; KEDRA, K.; NIZNIK, S. Ultrastructure and transovarial transmission of endosymbiotic microorganisms in Palaeococcus fuscipennis (Burmeister) (Insecta, Hemiptera, Coccinea: Monophlebidae). Folia Biologica, Praga, v. 54, n. 1, p. 69-74, 2006.

WILKINSON, T.L.; FUKATSU, T.; ISHIKAWA, H. Transmission of symbiotic bacteria Buchnera to parthenogenetic embryos in the aphid Acyrthosiphon pisum (Hemiptera:

Aphidoidea). Arthropod Structure \& Development, London, v. 32, n. 2, p. 241-245, 2003. 


\section{REVISÃO BIBLIOGRÁFICA}

\subsection{Aspectos comportamentais e importância econômica de Diaphorina citri}

Diaphorina citri, psilídeo sugador de seiva floemática, ataca preferencialmente brotações novas. As espécies hospedeiras deste psilídeo estão distribuídas em 25 gêneros de Rutaceae, sendo os gêneros Citropsis, Citrus e Murraya os hospedeiros preferenciais (CERMELI; MORALES; GODOY, 2006; HALL et al., 2012). Possui ampla distribuição mundial, com relatos de infestação em cultivos citrícolas da Ásia tropical e subtropical, África, Península Arábica, Ilhas Maurício e Reunião, algumas regiões da América do Sul, América Central e do Norte (HALBERT; MANJUNATH, 2004; HALL et al., 2012; BELOTI et al., 2013). Entre os prejuízos diretos ocasionados pelas sucessivas picadas e alimentação intensa em infestações elevadas, cita-se a perda excessiva de líquidos, que priva a planta de nutrientes, causando o enrolamento das folhas e o retorcimento dos brotos. As toxinas presentes na saliva liberada durante a perfuração do floema podem ainda levar a gema apical à morte, impedindo, assim, o crescimento normal da planta (THAO et al., 2000; YAMAMOTO; PAIVA; GRAVENA, 2001). Em período de brotação e clima favorável (clima quente e seco), a infestação é mais intensa (YAMAMOTO; PAIVA; GRAVENA, 2001).

Em termos nutricionais, a seiva elaborada é deficiente em compostos nitrogenados, principalmente aminoácidos essenciais, sendo rica em carboidratos. Tal condição exige que o inseto promova a concentração do alimento para a absorção eficiente de seus nutrientes, incorrendo, assim, na excreção de líquido açucarado que favorece o crescimento de fungos sobre a folha da planta, afetando sua atividade fotossintética (THAO et al., 2000; YAMAMOTO; PAIVA; GRAVENA, 2001).

Apesar dos danos diretos, D. citri assume importância por ser vetor dos agentes etiológicos do Huanglongbing (HLB) (PELZ-STELINSKI et al., 2010; TEIXEIRA et al., 2010). Essa doença é causada por bactérias do grupo Candidatus Liberibacter. A forma africana deste patógeno, Ca. Liberibacter africanum é transmitida por Trioza erytreae (Hemiptera: Triozidae), psilídeo que não ocorre no Brasil, enquanto a forma asiática, $C a$. Liberibacter asiaticum, juntamente com a forma presente em pomares brasileiros, $C a$. Liberibacter americanum, estão associadas a $D$. citri. No Brasil, Ca. L. asiaticus é a forma mais frequentemente associada a plantas com sintomas de HLB (BASSANEZI; MONTESINO; STUCHI, 2009; LOPES et al., 2009; TEIXEIRA et al., 2010). 
O HLB é considerado uma das piores doenças dos citros, apresentando alto impacto sócio-econômico em países da África e Ásia, onde mais de 50 milhões de árvores foram eliminadas devido a esta doença (HALBERT; MANJUNATH, 2004). No Estado de São Paulo, o maior produtor citrícola brasileiro, desde sua detecção no ano de 2004, mais de 3 milhões de plantas infectadas foram eliminadas como medida de controle da doença e, até recentemente, cerca de 5\% das plantas cítricas encontravam-se com sintomas de HLB (BELASQUE JR. et al., 2010). Os sintomas mais característicos da doença são gemas e brotos amarelados, folhas com aspecto mosqueado com manchas de coloração amarelo-pálidas, lembrando os sintomas da deficiência de zinco (YAMAMOTO; PAIVA; GRAVENA, 2001; GRAFTON-CARDWELL et al., 2006). Os frutos são frequentemente pequenos e deformados, sendo que a maturação inicia-se pela região do pedúnculo, diferenciando-se do processo normal, que se inicia pela região estilar (YAMAMOTO; PAIVA; GRAVENA, 2001). Com isso, o suco apresenta propriedades irregulares, como sabor amargo, baixo teor de sólidos solúveis e acidez elevada, além de apresentar sementes inviáveis (GOTTWALD; GRAÇA; BASSANEZI, 2007; BASSANEZI; MONTESINO; STUCHI, 2009).

\subsection{Bioecologia de Diaphorina citri}

Os adultos de Diaphorina citri medem entre 3-4 $\mathrm{mm}$ de comprimento. As fêmeas apresentam alta capacidade reprodutiva, depositando cerca de 800 ovos, em média, ao longo do seu período reprodutivo (LIU; TSAI, 2000; NAVA et al., 2007). Os ovos são alongados, medindo cerca de 0,31 $\mathrm{mm}$ de comprimento e $0,15 \mathrm{~mm}$ de diâmetro, possuem coloração inicial amarelo-claro, tornando-se alaranjados quando próximos à eclosão das ninfas (HALL et al., 2012). O período embrionário é de 3,5 dias a $27,5^{\circ} \mathrm{C}$ (NAKATA, 2006), variando de acordo com a temperatura (LIU; TSAI, 2000; NAKATA, 2006; NAVA et al., 2007). As formas imaturas são relativamente sésseis e apresentam cinco ínstares, com duração aproximada de 12 dias a $27,5^{\circ} \mathrm{C}$ (LIU; TSAI, 2000; NAKATA, 2006). A longevidade, assim como as demais características biológicas mencionadas anteriormente, pode variar de acordo com a temperatura e qualidade do hospedeiro no qual esse inseto é criado (LIU; TSAI, 2000; NAKATA, 2006; NAVA et al., 2007), mas há relatos de que o inseto é incapaz de completar seu desenvolvimento em temperaturas elevadas, como a $32^{\circ} \mathrm{C}$ (NAVA et al., 2007). 


\subsection{Interações endocitobiontes - sugadores de seiva}

Associações entre insetos e bactérias intracelulares são muito comuns na natureza, sendo estimado que cerca de $20 \%$ das espécies de insetos possuam endossimbiontes (DOUGLAS, 1998; FELDHAAR; GROSS, 2009). A presença de micro-organismos simbiontes intracelulares em insetos foi descrita pela primeira vez por Blochmann, sendo que a maioria dos simbiontes associados aos insetos não pode ser cultivada em meio artificial em virtude do alto grau de especialização adquirido na exploração do ambiente intracelular (BUCHNER, 1965; FELDHAAR; GROSS, 2009). Dois tipos distintos de endossimbiontes podem ser encontrados em insetos: (1) primários - vivem normalmente associados a estruturas especiais na hemocele do hospedeiro, os bacterócitos ou micetócitos, agrupados ou não em estruturas complexas, os bacteriomas ou micetomas, e são fundamentais para o crescimento e desenvolvimento do hospedeiro; (2) secundários ou facultativos - podem se alojar na maioria dos tecidos do hospedeiro, e a sua relação com o mesmo nem sempre é bem definida, por exemplo, Wolbachia, comum aos artrópodes (BAUMANN, 2005; GOTTLIEB et al., 2006; RATZKA; GROSS; FELDHAAR, 2012).

Os simbiontes primários são comumente associados a insetos de hábito alimentar especializado, restrito a uma fonte nutricional única, normalmente deficiente em nutrientes essenciais, e acabam suprindo seus hospedeiros com os nutrientes carentes em sua dieta natural (DOUGLAS, 1998; MORAN et al., 2005). Endossimbiontes têm ampla ocorrência entre os hemípteros da subordem Sternorrhyncha, tais como, Aphidoidea, Aleyrodoidea, Coccoidea e Psylloidea, que se alimentam predominantemente de seiva elaborada (SZKLARZEWICZ; MOSKAL, 2001; SZKLARZEWICZ; KEDRA; NIZNIK, 2006; KOGA et al., 2012; SLOAN; MORAN, 2012). Estudos histológicos indicaram a ocorrência destes simbiontes em células especializadas, os bacteriócitos, os quais podem formar agregados (bacterioma) na hemocele do inseto (MORAN; TELANG, 1998; BAUMANN, 2005).

Nos psilídeos, o tipo mais comum de bacterioma descrito consiste de uma grande estrutura amarelada, bilobada, constituída internamente de um sincício multinucleado circundado por bacteriócitos uninucleares arredondados, envoltos por uma grande quantidade de células alongadas (FUKATSU; NIKOH, 1998; BAUMANN, 2005). O citoplasma dos bacteriócitos é repleto do simbionte primário, a bactéria Candidatus Carsonella ruddii, enquanto o citoplasma sincicial é preenchido pelo simbionte $C a$. Profftella armatura (FUKATSU; NIKOH, 1998; BAUMANN, 2005; NAKABACHI et al.; 2013). 
Diversos mecanismos foram desenvolvidos para assegurar a transmissão de endossimbiontes do bacterioma materno para a progênie. Na maioria das espécies, os simbiontes são transmitidos verticalmente, por via transovariana. Nestes casos, ocorre a infecção do oócito pelos micro-organismos contidos no bacterioma da mãe. Os simbiontes podem infectar células germinativas imaturas, como oogônia ou oócitos pré-vitelogênicos, ou invadir oócitos em estágio avançado de maturação (BILÍNSKI; BÜNING, 1998; ZELAZOWSKA; BILÍNSKI, 1999; SACCHI et al., 2008). Em ninfas de Anoplura, os bacteriócitos se distribuem entre as células epiteliais do intestino médio ou formam bacteriomas na superfície ventral deste órgão, sendo transferidos para o ovário durante a última ecdise da fêmea, onde formam bacteriomas dentro dos ovidutos laterais; mecanismos semelhantes foram descritos para alguns cupins e baratas (EBERLE; MCLEAN, 1982; ŻELAZOWSKA; BILIŃSKI, 1999; SACCHI et al., 2000). Entre Sternorrhyncha, Aleurochiton aceris (Hemiptera: Aleyrodidae) (SZKLARZEWICZ; MOSKAL, 2001) e $D$. citri apresentam uma forma distinta de transmissão dos endossimbiontes, pois bacteriócitos intactos migram para os ovários, invadindo os oócitos em desenvolvimento (DOSSI, 2008). Em outros membros deste grupo, os simbiontes deixam o bacteriócito e adentram as células germinativas (BUCHNER, 1965; BAUMANN, 2005). Em Acyrthosiphon pisum (Hemiptera: Aphididae), simbiontes são transmitidos verticalmente, tanto em formas sexuadas quanto partenogenéticas (MIURA et al., 2003), que envolve um complexo mecanismo de exo- e endocitose na transferência seletiva de simbiontes como forma de assegurar a continuidade da associação obrigatória hospedeiro-simbionte (KOGA et al., 2012).

\subsection{Desenvolvimento embrionário e formação de estruturas que abrigam simbiontes}

A embriogênese em insetos é marcada por fenômenos complexos e diversos (SCHWALM, 1997; STERN, 2004). Diferenças relevantes entre grupos de insetos, relacionadas à duração do período embrionário, podem estar associadas à forma, tamanho e padrão de clivagem do ovo (ANDERSON, 1972; JURA, 1972), além da distribuição de morfógenos (GILBERT, 1997), fatores ambientais (SANDER; GUTZEIT; JÄCKLE, 1985) e a influência de interações com micro-organismos simbiontes (SCHWEMMLER, 1974; LAUDANI et al., 1995; BRAENDLE et al., 2003).

O desenvolvimento embrionário é regido por gradientes morfogenéticos presentes no citoplasma do ovo (ooplasma), moléculas conservadas evolutivamente, responsáveis pela determinação dos eixos ântero-posterior e dorso-ventral do embrião, sinalização e distribuição 
celular e a ativação e desligamento de genes, durante todo o período embrionário (GILBERT, 1997; DAVIS; PATEL, 2002). Desde que o vitelo ocupa a região central do ooplasma em insetos, a embriogênese, iniciada por anfimixia, caracteriza-se por uma série de divisões mitóticas sincrônicas, das quais participam núcleos contidos em halos citoplasmáticos (enérgidas) dispersos no ooplasma, formando um sincício. As enérgidas afastam-se entre si a cada divisão por influência de arranjos microtubulares associados ao núcleo e migram em direção ao periplasma, região cortical livre de vitelo e logo abaixo da membrana vitelínica (COUNCE, 1973; CALLAINI et al., 1994).

Apesar de haver variações entre espécies de grupos distintos, é possível distinguir dois padrões básicos de formação da blástula, os quais se caracterizam pela 1) emergência sincronizada de enérgidas no periplasma, precedida de migração uniforme pelo eixo ânteroposterior do ovo, presente em representantes de Odonata, Ephemeroptera, Plecoptera, Embioptera, Dermaptera, Diptera, Coleoptera e Paraneoptera (ANDERSON, 1972; SCHWALM, 1997; ROTH, 2004), e pela 2) emergência polarizada, processo de ocupação desuniforme do periplasma a partir do pólo posterior, levando a um gradiente de celularização da blástula de forma progressiva em direção ao pólo anterior, como relatado em Schistocerca e Locusta (ANDERSON, 1972; HO et al., 1997; ROTH, 2004). A blástula sincicial (préblástula ou blastema) resultante da disposição de enérgidas no periplasma torna-se celularizada em decorrência de invaginações da membrana vitelínica por entre os núcleos, formando a blástula (MIYAMOTO; VAN DER MEER, 1982; SANDER; GUTZEIT; JÄCKLE, 1985; SCHWALM, 1997). Na sequência do desenvolvimento, fatores morfogenéticos especificam a diferenciação de formato e densidade de blastômeros presentes em regiões específicas da blástula, dando origem ao embrião rudimentar ${ }^{1}$, enquanto as demais células originam os tecidos extraembrionários (âmnio e serosa) (COUNCE, 1961; SCHWALM, 1997; DAVIS; PATEL, 2002). A partir da blastulação, a embriogênese varia consideravelmente entre os grupos de insetos, em termos de quando e onde ocorre a segmentação do plano corporal, sendo assim reconhecidas três formas de desenvolvimento embrionário a partir das bandas germinativas: curta, intermediária e longa (DAVIS; PATEL, 2002).

1 Em insetos, somente parte da blastoderme é destinada a originar o embrião. O conjunto de células, formado por migração ou diferenciação in situ, que se distinguem daquelas relacionadas à formação das membranas extraembrionárias, são denominadas embrião rudimentar ou primordial (= "germ anlage") (Counce, 1961), ou ainda, em termos gerais, banda germinativa (= "germ band") (Schwalm, 1997; Roth, 2004). 
Com exceção de alguns Coleoptera, insetos holometábolos possuem banda germinativa longa, no qual há a determinação de todos os segmentos corporais prospectivos durante a fase de blástula, os quais podem ser distinguidos antes do período de gastrulação. Em folhetos germinativos extremamente curtos (ex. Phasmatodea e Isoptera), não há delimitação de segmentos primordiais e, desta forma, acredita-se que todos os segmentos embrionários sejam desenvolvidos em sentido ântero-posterior, a partir de uma zona de crescimento. Entretanto, insetos que possuem banda germinativa curta, a exemplo de Schistocerca e Xiphidium (Orthoptera) e Atrachya (Coleoptera), apenas os segmentos cefálicos estão especificados durante a fase de blástula, sendo os segmentos restantes formados posteriormente, inclusive durante a gastrulação (DAVIS; PATEL, 2002; ROSENBERG; LYNCH; DESPLAN, 2009)

Hemimetábolos distribuídos em diferentes ordens, inclusive Hemiptera, possuem banda germinativa intermediária em comparação aos padrões supracitados, estando especificados os segmentos primordiais da cabeça e do tórax, sendo os segmentos abdominais formados posteriormente a gástrula (ANDERSON, 1972; ROTH, 1997; SANDER, 1997; DAVIS; PATEL, 2002; MIURA et al., 2003; MYIAWAKI et al., 2004). O embrião rudimentar, durante os estágios de formação dos folhetos extraembrionários e antes do processo de alongamento ântero-posterior, constitui-se de um epitélio simples, correspondente à ectoderme prospectiva. Durante o período de formação da gástrula, ocorre a internalização (por invaginação ou migração multipolar) de células mesodérmicas localizadas na superfície ventral do embrião rudimentar, constituindo a banda germinativa (COUNCE, 1961; SCHWALM, 1997).

Em insetos, não há formação de um epitélio endodérmico de forma semelhante ao observado para mesoderme e ectoderme. Os equivalentes mais próximos são os vitelófagos e pequenos grupos celulares endodérmicos provenientes de regiões da ectoderme, que concorrem para a formação do intestino médio (SANDER; GUTZEIT; JÄCKLE, 1985). Juntamente com o processo de alongamento da banda germinativa superficialmente ao vitelo, ocorre o início da anatrepsis, movimento embrionário caracterizado pela imersão do embrião no vitelo, principalmente nas espécies de banda germinativa longa e intermediária. A catatrepsis, movimento contrário que posiciona o embrião no sentido ântero-posterior, completa a blastocinese durante o desenvolvimento tardio da banda germinativa. Associadas a um grupo de células endodérmicas posteriores (mesêntero prospectivo) invaginantes no ponto de formação do proctodéu, células polares (células germinativas prospectivas) penetram o embrião, sendo circundadas pelos componentes mesodérmicos das gônadas. 
Concomitantemente ao alongamento da banda germinativa, uma série de processos morfogeneticamente especificados promovem a segmentação e organogênese no embrião (ROTH, 2004; PANFILIO, 2008).

\subsection{Efeitos do estresse térmico sobre a densidade de simbiontes a a estabilidade da associação com o hospedeiro}

Os efeitos da tolerância ao estresse térmico, mediada por simbiontes, são dependentes da densidade e da própria termotolerância dos simbiontes envolvidos (CHANG, 1974; BURKE; FIEHN; MORAN, 2010; OLIVER, et al., 2010). A exposição ao estresse térmico de pulgões infectados apenas com o simbionte primário Buchnera, responsável pela suplementação nutricional do hospedeiro, provocou drástica diminuição da densidade deste simbionte, afetando o desempenho biológico do hospedeiro (BURKE; FIEHN; MORAN, 2010; OLIVER, et al., 2010). Entretanto, pulgões que continham o simbionte Buchnera e os simbiontes secundários Serratia symbiotica e/ou Regiella inseticola, apresentaram aumento da tolerância ao estresse térmico, sendo que o efeito protetivo foi estendido ao simbionte Buchnera, refletido na manutenção de sua densidade (OHTAKA; ISHIKAWA, 1991; CHEN et al., 2000; MONTLLOR et al., 2002; BURKE; FIEHN; MORAN, 2010). Adicionalmente, pulgões apresentaram melhor desempenho reprodutivo, comportamento atribuído, pelo menos em parte, à degradação do simbionte S. symbiotica, cuja densidade foi reduzida pela metade logo após o tratamento térmico, com subsequente recuperação ao longo do desenvolvimento do hospedeiro (BURKE; FIEHN; MORAN, 2010). Tais efeitos também foram observados sobre a densidade do simbionte obrigatório do percevejo Cimex lectularius (Hemiptera: Cimicidae), o qual foi eliminado dos bacteriócitos em consequência do choque térmico, resultando na alta mortalidade do hospedeiro (CHANG, 1974).

A ativação de vias de sinalização intracelular em resposta ao estresse térmico induzem a expressão de moléculas antioxidantes e de chaperonas, visando minimizar os efeitos deletérios ao organismo (CHANG, 1974; GRAZIOSI et al., 1983; FEDER; HOFMANN, 1999). Entretanto, se presentes em concentrações muito elevadas, tais substâncias podem exercer efeito nocivo à própria célula (FEDER; HOFMANN, 1999). A expressão de proteínas de estresse (chaperonas), nas fases iniciais do desenvolvimento embrionário de invertebrados, ocorre a partir da tradução de mRNA materno, podendo haver regulação severa devido aos efeitos deletérios e interferência na padronização do embrião (GRAZIOSI et al., 1983; FEDER; HOFMANN, 1999). No entanto, a capacidade de utilização desse mecanismo como 
forma de proteção celular torna-se maior conforme o avanço da embriogênese, sendo que embriões de Drosophila são capazes de expressar genes de chaperonas de choque térmico (heat shock proteins - HSP) em condições de estresse térmico após a formação da blástula, regulando sua concentração no interior celular (GRAZIOSI et al., 1983; KREBS; FEDER, 1998). Além da síntese de chaperonas relacionadas à manutenção da homeostase intracelular, promovida pelo simbionte Buchnera (MORIOKA; ISHIKAWA, 1992; BAUMANN; MORAN; BAUMANN, 1997), simbiontes secundários de pulgões (CHEN; MONTLLOR; PURCELL, 2000; MONTLLOR et al., 2002; OLIVER et al., 2010) e moscas-brancas (MAHADAV et al., 2009) podem sintetizar chaperonas de choque térmico, conferindo proteção ao sistema. A interferência das HSPs foi sugerida como fator que reduz a expressão dos fenótipos reprodutivos induzidos por Wolbachia (FEDER et al., 1999), concomitantemente aos efeitos inibidores do tratamento térmico sobre a densidade de infecção de Wolbachia no hospedeiro (HURST et al., 2000; SARIDAKI; BOURTZIS, 2010; BORDENSTEIN; BORDENSTEIN, 2011).

Tratamentos de choque térmico podem resultar em alterações ultraestruturais em simbiontes intracelulares (CHANG, 1974; ZHUKOVA; VORONIN; KISELEVA, 2008). Em Drosophila melanogaster (Diptera: Drosophilidae), a curta exposição de ovos ao choque térmico durante a embriogênese inicial, parece promover alterações morfofuncionais em Wolbachia, estimulando mecanismos de secreção, interação com membranas do retículo endoplasmático (ZHUKOVA; VORONIN; KISELEVA, 2008), a interferência na síntese de HSPs (FEDER et al., 1999), e na manipulação de mecanismos de estresse oxidativo (SARIDAKI; BOURTZIS, 2010). Em face à importância das interações inseto-simbionte, a perda de simbiontes mutualistas obrigatórios, como consequência dos efeitos relacionados ao estresse térmico, frequentemente resulta no comprometimento reprodutivo ou mesmo na morte do hospedeiro (CHANG, 1974; CHEN; LAI; KUO, 2009).

\subsection{Estabelecimento de simbiontes durante a embriogênese}

Diversas adaptações morfofisiológicas desenvolvidas pelos insetos foram relevantes para o seu sucesso evolutivo (ISHIKAWA, 2003; CHOWN; NICOLSON, 2004). Entre elas pode-se destacar a capacidade de interação com micro-organismos mutualistas, tendo em vista o amplo leque de vantagens bioecológicas decorrentes, como o aumento de desempenho biológico sobre plantas hospedeiras, a exploração de nichos nutricionalmente limitados, a maior tolerância ao estresse térmico, resistência a xenobióticos e inimigos naturais, entre 
outros (DOWD; SHEN, 1990; DOUGLAS, 1998; TSUCHIDA et al., 2004; OLIVER et al., 2005; DUNBAR et al., 2007). Nesse contexto, muitos insetos, e notavelmente a maioria dos hemípteros e alguns coleópteros, desenvolveram mecanismos complexos para assegurar sua associação com simbiontes ao longo de gerações (BUCHNER, 1965; ISHIKAWA, 2003; BAUMANN, 2005).

Durante o processo de transmissão, simbiontes intracelulares podem ser submetidos, isolada ou agregadamente, a um ou mais estágios extracelulares, atingindo, finalmente, células (micetócitos ou bacteriócitos) e/ou tecidos especializados (micetoma ou bacterioma) em abrigá-los no interior do hospedeiro (BUCHNER, 1965; SANDER; GUTZEIT; JÄCKLE, 1985; BAUMANN, 2005). A internalização de micro-organismos simbiontes no deutoplasma pode ser considerada um dos mecanismos iniciais de grande relevância na colonização do embrião hospedeiro. Em alguns coccídeos, o núcleo de corpos polares une-se às enérgidas e, após várias divisões, dá origem a células poliplóides formadoras do bacterioma (COUNCE, 1961; NORMARK, 2004). Os bacteriócitos prospectivos de pulgões invadem a massa de simbiontes em duas etapas do desenvolvimento embrionário, resultando em uma estrutura constituída de bacteriócitos agregados, semelhante a um bacterioma (BAUMANN, 2005; KOGA et al., 2012). Diversas funções são atribuídas aos vitelófagos durante o desenvolvimento embrionário, incluindo mecanismos de contração do deutoplasma em consequência da transformação do vitelo, síntese de ácidos nucléicos e proteínas, fagocitose e atividades relacionadas à movimentação de aglomerados de simbiontes no deutoplasma (também denomidados como complexos intradeutoplasmáticos) e formação de bacteriócitos e bacterioma (COUNCE, 1961; BUCHNER, 1965; KÖRNER, 1972; PÉTAVY, 1986; LAUDANI et al., 1995).

Buchner (1965) relatou a formação do bacterioma em Aleurodes protetella (Hemiptera: Aleyrodidae) a partir de núcleos embrionários, os quais substituem o núcleo e citoplasma do bacteriócito materno. Segundo Miura et al. (2003), mecanismos distintos de internalização de simbiontes ocorrem entre formas sexuadas e partenogenéticas do pulgão Acyrthosiphon pisum (Hemiptera: Aphidade). Em embriões de formas sexuadas há a incorporação de bactérias simbiontes concomitantemente à anatrepsis, e um núcleo não definido, localizado na região posterior do ovo, invade a massa de simbiontes, supostamente formando o núcleo do bacteriócito primário. Entretanto, embriões partenogenéticos são invadidos por bactérias durante o período de blástula, por um mecanismo complexo, envolvendo exo- e endocitose, com a participação de supostas barreiras de contenção constituídas de microfilamentos (KOGA et al., 2012). Em Psylla alni (Hemiptera: Psyllidae), 
vitelófagos associam-se à massa de simbiontes logo após a formação da blástula. Os mecanismos envolvidos na formação do bacterioma nesta espécie envolvem a transferência seletiva de simbiontes para os vitelófagos formadores dos bacteriócitos e do tecido sincicial do bacterioma, sendo que os núcleos provisórios do sincício passam por um período de intensa multiplicação (BUCHNER, 1965).

As estruturas responsáveis em abrigar simbiontes desenvolvem-se mesmo quando os simbiontes são eliminados experimentalmente (SCHWEMMLER, 1974), havendo evidências de sua ocorrência mesmo em espécies que perderam ou substituíram seus simbiontes no processo evolutivo (BRAENDLE et al., 2003). Dessa forma, as supostas funções fisiológicas desses micro-organismos no ovo permanecem obscuras, apesar de serem necessários ao desenvolvimento normal do embrião de Euscelis plebejus (Hemiptera: Cicadellidae), por exemplo. Nesta espécie, há uma relação positiva entre o volume da massa de simbiontes no ovo e o tempo de desenvolvimento do embrião, sendo que quanto menor a quantidade de simbiontes na massa, maior o atraso no desenvolvimento do embrião. Além disso, quando os simbiontes são parcial ou totalmente eliminados do ovo, ocorre formação de embrião deformado, com um número reduzido de segmentos na cabeça e abdome, ou desprovido de abdome, respectivamente (SCHWEMMLER, 1974).

Apesar de fundamentais na biologia de psilídeos (SUBANDIYAH et al., 2000; NAKABACHI et al., 2006; SLOAN; MORAN, 2012), inclusive dada sua transmissão transovariana para a progênie (DOSSI, 2008), nada consta na literatura sobre o comportamento dos endossimbiontes associados a D. citri durante o desenvolvimento embrionário deste psilídeo. Desse modo, a caracterização da distribuição de simbiontes primários e os mecanismos envolvidos na formação do bacterioma de $D$. citri durante a embriogênese, principalmente sob o ponto de vista morfológico, permitirão melhor compreender a relação dessas bactérias com seu hospedeiro, bem como fundamentar novos estudos aplicados ao seu manejo. 


\section{Referências}

ANDERSON, D.T. The development of hemimetabolous insects. In: COUNCE, S.J.; WADDINGTON, C.H. (Ed.). Developmental systems: insects. London: Academic Press, 1972. p. $95-163$.

BASSANEZI, R.B.; MONTESINO, L.H.; STUCHI, E.S. Effects of huanglongbing on fruit quality of sweet orange cultivars in Brazil. European Journal of Plant Pathology, London, v. 125, n. 4, p. 565-572, 2009.

BAUMANN, P. Biology bacteriocyte-associated endosymbionts of plant sap-sucking insects. Annual Review of Microbiology, Palo Alto, v. 59, p. 155-159, 2005.

BAUMANN, P.; MORAN, N.A.; BAUMANN, L. The evolution and genetics of aphid endosymbionts. BioScience, Berkeley, v. 47, p. 12-20, 1997.

BELASQUE JR. J.B.; BARBOSA, J.C.; MASSARI, C.A.; AYRES, A.J. Incidência e distribuição do huanglongbing no estado de São Paulo, Brasil. Citrus Research \& Technology, São Paulo, v. 31, n. 1, p. 1-9, 2010.

BELOTI, V.H.; RUGNO, G.R.; FELIPPE, M.R.; CARMO-UEHARA, A.; GARBIM, L.F.; GODOY, W.A.C.; YAMAMOTO, P.T. Population dynamics of Diaphorina citri Kuwayama (Hemiptera: Liviidae) in orchards of 'Valencia' orange, 'Ponkan' mandarim and 'Murcott' tangor trees. Florida Entomologist, Lutz, v. 96, n. 1, p. 173-179, 2013.

BILÍNKI, S.M.; BÜNING, J. Structure of ovaries and oogenesis in the snowfly Boreus hyemalis (Linne) (Mecoptera: Boreidae). International Journal Insect Morphology and Embryology, New York, v. 27, p. 333-340, 1998.

BORDENSTEIN, S.R.; BORDENSTEIN, S.R. Temperature affects the tripartite interactions between bacteriophage WO, Wolbachia, and cytoplasmic incompatibility. PloS ONE, San Francisco, v. 6, n. 12, p. e29106, 2011.

BUCHNER, P. Endosymbiosis of animals with plant microorganisms. New York: John Wiley, 1965. 909p.

BURKE, G.; FIEHN, O.; MORAN, N. Effects of facultative symbionts and heat stress on the metabolome of pea aphids. The ISME Journal, New York, v. 4, n. 2, p. 242-252, 2010.

CALLAINI, G.; RIPARBELLI, M.G.; DALLAI, R. The distribution of cytoplasmic bacteria in the early Drosophila embryo is mediated by astral microtubules. Journal of Cell Science, London, v. 107, p. 673-682, 1994.

CERMELI, M.; MORALES, P.; GODOY, F. Presencia del psílido asiático de los cítricos Diaphorina citri Kuwayama (Hemiptera : Psyllidae ) en Venezuela. Boletín de Entomología Venezulana, Caracas, v. 15, n. 2, p. 1-7, 2006.

CHANG, K.P. Effects of elevated temperature on the mycetome and symbiotes of the bed bug Cimex lectularius (Heteroptera). Journal of Invertebrate Pathology, San Diego, v. 23, n. 3, p. 333-340, 1974. 
CHEN, C.; LAI, C.; KUO, M. Temperature effect on the growth of Buchnera endosymbiont in Aphis craccivora (Hemiptera: Aphididae). Symbiosis, Dordrecht, v. 49, n. 1, p. 53-59, 2009.

CHEN, D.Q.; MONTLLOR, C.B.; PURCELL, A.H. Fitness effects of two facultative endosymbiotic bacteria on the pea aphid, Acyrthosiphon pisum, and the blue alfalfa aphid, $A$. kondoi. Entomologia Experimentalis et Applicata, Malden, v. 95, n. 3, p. 315-323, 2000.

CHOWN, S.L.; NICOLSON, S. Insect physiological ecology: mechanisms and patterns. Oxford: Oxford University Press, 2004. 243p.

COUNCE, S.J. The analysis of insect embryogenesis. Annual Review of Entomology, Standford, v. 6, p. 295-312, 1961.

. The causal analysis of insect embryogenesis. In: COUNCE, S.J.; WADDINGTON, C.H. (Ed.). Developmental systems: insects. London: Academic Press, 1973. p. 1-156.

DAVIS, G.K.; PATEL, N.H. Short, long and beyond: molecular and embryological approaches to insect segmentation. Annual Review of Entomology, Palo Alto, v. 47, p. 669699, 2002.

DOUGLAS, A.E. Nutritional interactions in insect-microbial symbioses: aphids and their symbiotic bacteria Buchnera. Annual Review of Entomology, Palo Alto, v. 43, p. 17-37, 1998.

DOWD, P.F.; SHEN, S.K. The contribution of symbiotic yeast to toxin resistance of the Cigarette beetle (Lasioderma serricorne). Entomologia Experimentalis et Applicata, Malden, v. 56, p. 241-248, 1990.

DUNBAR, H.E.; WILSON, A.C.C.; FERGUSON, N.R.; MORAN, N.A. Aphid thermal tolerance is governed by a point mutation in bacterial symbionts. PLoS Biology, San Francisco, v. 5, n. 5, p. e96, 2007.

EBERLE, M.W.; MCLEAN, D.L. Initiation and orientation of the symbiote migration in the human body louse Pediculus humanus L. Journal of Insect Physiology, Oxford, v. 28, n. 5, p. 417-422, 1982.

FEDER, M.E.; HOFMANN, G.E. Heat-shock proteins, molecular chaperones, and the stress response: evolutionary and ecological physiology. Annual Review of Physiology, Palo Alto, v. 61, p. 243-282, 1999.

FEDER, M.E.; KARR, T.L.; YANG, W.; HOEKSTRA, J.M.; JAMES, A.C. Interaction of Drosophila and its endosymbiont Wolbachia: natural heat shock and the overcoming of sexual incompatibility. Integrative and Comparative Biology, Cary, v. 39, n. 2, p. 363-373, 1999.

FELDHAAR, H.; GROSS, R. Insects as hosts for mutualistic bacteria. International Journal of Medical Microbiology, Jena, v. 299, n. 1, p. 1-8, 2009. 
FUKATSU, T.; NIKOH, N. Two intracellular symbiotic bacteria from the mulberry psyllid Anomoneura mori (Insecta, Homoptera). Applied and Environmental Microbiology, Washington, v. 64, n. 10, p. 3599-3606, 1998.

GILBERT, S.F.; RAUNIO, A.M. Embryology: constructing the organism. Massachusetts: Sinauer Associates, 1997. 537p.

GOTTLIEB, Y.; GHANIM, M.; CHIEL, E.; GERLING, D.; PORTNOY, V.; STEINBERG, S.; TZURI, G.; HOROWITZ, A.R.; BELAUSOV, E.; DAUBE, N.M.; KONTSEDALOV, S.; GERSHON, M.; GAL, S.; KATZIR, N.; FEIN, E.Z. Identification and localization of a Rickettsia sp. in Bemisia tabaci (Homoptera : Aleyrodidae). Applied and Environmental Microbiology, Washington, v. 72, n. 5, p. 3646-3652, 2006.

GOTTWALD, T.R.; GRAÇA, J.V.; BASSANEZI, R.B. Citrus huanglongbing: the pathogen and its impact. Plant Health Progress, online, 2007. doi:10.1094/PHP-2007-0906-01-RV. Disponível em: http://www.plantmanagementnetwork.org/pub/php/review/2007/huanglongbing/. Acesso em: 27 maio 2013.

GRAFTON-CARDWELL, E.E.; GODFREY, K.E.; ROGERS, M.E.; CHILDERS, C.C.; STANSLY, P.A. Asian citrus psyllid. ANR Publication - University of California, Berkeley, n. 8205, p. 1-8, 2006.

GRAZIOSI, G.; CRISTINI, F.; MARCOTTULLIO, A.; MARZARI, R.; MICALI, F.; SAVOINI, A. Morphological and molecular modifications induced by heat shock in Drosophila melanogaster embryos. Journal of Embryology and Experimental Morphology, London, v. 77, p. 167-182, 1983.

HALBERT, S.E.; MANJUNATH, K.L. Asian citrus psyllids (Sternorrhyncha: Psyllidae) and greening disease of citrus: a literature review and assessment of risk in Florida. Florida Entomologist, Lutz, v. 87, n. 3, p. 330-353, 2004.

HALL, D.G.; RICHARDSON, M.L.; AMMAR, E.D.; HALBERT, S.E. Asian citrus psyllid, Diaphorina citri, vector of citrus huanglongbing disease. Entomologia Experimentalis et Applicata, Malden, v. 146, n. 2, p. 207- 223, 2012.

HO, K.; DUNIN-BORKOWSKI, O.M.; AKAM, M. Cellularization in locust embryos occurs before blastoderm formation. Development, Cambridge, v. 124, p. 673-682, 1997.

HURST, G.D.; JOHNSON, A.L.; SCHULENBURG, J.H.G.; FUYAMA, Y. Male-killing Wolbachia in Drosophila: a temperature-sensitive trait with a threshold bacterial density. Genetics, Bethesda, v. 156, n. 2, p. 699-709, 2000.

ISHIKAWA, H. Insect symbiosis: an introduction. In: BOURTZIS, K.; MILLER, T.A. (Ed.). Insect symbiosis. Boca Raton: CRC Press, 2003. p. 1-16.

JURA, C. Development of apterygote insects. In: COUNCE, S.J.; WADDINGTON, C.H. (Ed.). Developmental systems: insects. London: Academic Press, 1972. p. 49-94. 
KOGA, R.; MENG, X.Y.; TUSUCHIDA, T.; FUKATSU, T. Cellular mechanism for selective vertical transmission of an obligate insect symbiont at the bacteriocyte-embryo interface. Proceedings of the National Academy of Sciences of the United States of America, Washington, v. 109, n. 20, p. 1230-1237, 2012.

KORNER, H.K. Elektronenmikroskopische untersuchungen am embryonalen mycetom der kleinzikade Euscelis plebejus fall. (Homoptera, Cicadina). Zeitschrift Für Parasitenkunde, Berlin, v. 40, n. 3, p. 203-226, 1972.

KREBS, R.A.; FEDER, M.E. Hsp70 and larval thermotolerance in Drosophila melanogaster: how much is enough and when is more too much? Journal of Insect Physiology, Oxford, v. 44, n. 11, p. 1091-1101, 1998.

LAUDANI, U.; GRIGOLO, A.; SACCHI, L.; CORONA, S.; BISCALDI, G. On the mycetome formation in Periplaneta americana (Blattaria, Blattidae). Italian Journal of Zoology, Oxon, v. 62, n. 4, p. 345-351, 1995.

LIU, Y.H.; TSAI, J.H. Effects of temperature on biology and life table parameters of the Asian citrus psyllid, Diaphorina citri Kuwayama (Homoptera: Psyllidae). Annals of Applied Biology, London, v. 137, n. 3, p. 201-206, 2000.

LOPES, S.A.; FRARE, G.F.; BERTOLINI, E.; CAMBRA, M.; FERNANDES, N.G.; AYRES, A.J.; MARIN, D.R.; BOVÉ, J.M. Liberibacters associated with citrus huanglongbing in brazil: 'Candidatus Liberibacter asiaticus' is heat tolerant, ' $\mathrm{Ca}$. L. americanus' is heat sensitive. Plant Disease, St. Paul, v. 93, n. 3, p. 257-262, 2009.

MAHADAV, A.; KONTSEDALOV, S.; CZOSNEK, H.; GHANIM, M. Thermotolerance and gene expression following heat stress in the whitefly Bemisia tabaci B and Q biotypes. Insect Biochemistry and Molecular Biology, Oxford, v. 39, n. 10, p. 668-676, 2009.

MIURA, T.; BRAENDLE, C.; SHINGLETON, A.; SISK, G.; KAMBLAMPATI, S.; STERN, D.L. A comparison of parthenogenetic and sexual embryogenesis of the pea aphid Acyrthosiphon pisum (Hemiptera: Aphidoidea). Journal of Experimental Zoology Part B: Molecular and Developmental Evolution, Washington, v. 295, n. 1, p. 59-81, 2003.

MONTLLOR, C.B.; MAXMEN, A.; PURCELL, A.H. Facultative bacterial endosymbionts benefit pea aphids Acyrthosiphon pisum under heat stress. Ecological Entomology, Malden, v. 27, n. 2, p. 189-195, 2002.

MORAN, N.A.; TELANG, A. Bacteriocyte-associated symbionts of insects. BioScience, Washington, v. 48, n. 4, p. 295-304, 1998.

MORAN, N.A.; DEGNAM, P.H.; SANTOS, S.R.; DUNBAR, H.E.; OCHMAN, H. The players in a mutualistic symbiosis: Insects, bacteria, viruses, and virulence genes.

Proceedings of the National Academy of Sciences of the United States of America, Washington, v. 102, n. 47, p. 16919-16926, 2005.

MORIOKA, M.; ISHIKAWA, H. Mutualism based on stress: selective synthesis and phosphorylation of a stress protein by an intracellular symbiont. Journal of Biochemistry, Oxford, v. 111, n. 4, p. 431-435, 1992. 
MYIAMOTO, D.M.; VAN DER MEER, J.M. Early egg contractions and patterned parasynchronous cleavage in a living insect egg. Wilhelm Roux's Archives of Development Biology, Berlin, v. 191, p. 95-102, 1982.

MYIAWAKI, K.; MITO, T.; SARASHINA, I.; ZHANG, H.; SHINMIO, Y.; OHUCHI, H.; NOJI, S. Involvement of Wingless/Armadillo signaling in the posterior sequential segmentation in the cricket, Gryllus bimaculatus (Orthoptera), as revealed by RNAi analysis. Mechanisms of Development, Amsterdam, v. 121, p. 119-130, 2004.

NAKABACHI, A. YAMASHITA, A.; TOH, H.; ISHIKAWA, H.; DUNBAR, H.E.; MORAN, N.A.; HATTORI, M. The 160-kilobase genome of the bacterial endosymbiont Carsonella. Science, Washington, v. 314, n. 5797, p. 267, 2006.

NAKABACHI, A.; UEOKA, R.; OSHIMA, K.; TETA, R.; MANGONI, A.; GURGUI, M.; OLDHAM, N.J.; van ECHTEN-DECKERT, G.; OKAMURA, K.; YAMAMOTO, K.; INOUE, H.; OHKUMA, M.; HONGOH, Y.; MIYAGISHIMA, S.; HATTORI, M.; PIEL, J.; FUKATSU, T. Defensive bacteriome symbiont with a drastically reduced genome. Current Biology, Cambridge, v. 23, n. 15, p. 1478-1484, 2013.

NAKATA, T. Temperature-dependent development of the citrus psyllid, Diaphorina citri (Homoptera: Psylloidea), and the predicted limit of its spread based on overwintering in the nymphal stage in temperate regions of Japan. Applied Entomology and Zoology, Tokyo, v. 41, n. 3, p. 383-387, 2006.

NAVA, D.E.; TORRES, M.L.G.; RODRIGUES, M.D.L.; BENTO, J.M.S.; PARRA, J.R.P. Biology of Diaphorina citri (Hem. Psyllidae) on different hosts and at different temperatures. Journal of Applied Entomology, Malden, v. 131, n. 9, p. 709-715, 2007.

NORMARK, B.B. The strange case of the armored scale insect and its bacteriome. PLoS Biology, San Francisco, v. 2, n. 3, p. 298-301, 2004.

OLIVER, K.M.; MORAN, N.A.; HUNTER, M.S. Variation in resistance to parasitism in aphids is due to symbionts not host genotype. Proceedings of the National Academy of Sciences of the United States of America, Washington, v. 102, n. 36, p. 12795-12800, 2005.

OLIVER, K.M.; RUSSELL, J.A.; MORAN, N.A.; HUNTER, M.S. Facultative bacterial symbionts in aphids confer resistance to parasitic wasps. Proceedings of the National Academy of Sciences of the United States of America, Washington, v. 100, n. 4, p. 1803 1807, 2003.

PANFILIO, K. Extraembryonic development in insects and the acrobatics of blastokinesis. Developmental Biology, Washington, v. 313, p. 471-491, 2008.

PELZ-STELINSKI, K.S.; BRLANSKY, R.H.; EBERT, T.A.; ROGERS, M.E. Transmission parameters for candidatus liberibacter asiaticus by Asian Citrus Psyllid (Hemiptera: Psyllidae). Journal of Economic Entomology, Lanham, v. 103, n. 5, p. 1531-1541, 2010.

PÉTAVY, G. Contribution of the vitellophags to yolk digestion and cytophagocytosys during embryogenesis of the migratory locust, Locusta migratoria L. (Orthoptera: Acrididade). 
International Journal of Insect Morphology and Embryology, Oxon, v. 15, n. 5/6, p. 343$361,1986$.

RATZKA, C.; GROSS, R.; FELDHAAR, H. Endosymbiont tolerance and control within insect hosts. Insects, Austin, v. 3, n. 4, p. 553-572, 2012.

ROSENBERG, M.; LYNCH, J.; DESPLAN, C. Heads and tails: evolution of antero-posterior patterning in insects. Biochimica et Biophysica Acta - Gene Regulatory Mechanisms, New York, v. 1789, n. 4, p. 333-342, 2009.

ROTH, S. Gastrulation in other insects. In: STERN, C.D. (Ed.). Gastrulation: from cells to embryo. New York: Cold Spring Harbor Laboratory Press, 2004. p. 105-121.

SACCHI, L.; NALEPA, C.A.; LENZ, M.; BANDI, C.; CORONA, S.; GRIGOLO, A.; BIGLIARDI, E. Transovarial transmission of symbiotic bacteria in Mastotermes darwiniensis (Isoptera: Mastotermitidae): ultrastructural aspects and phylogenetic implications. Annals of the Entomological Society of America, Lanham, v. 93, n. 6, p. 1308-1313, 2000.

SACCHI, L.; GENCHI, M.; CLEMENTI, E.; BIGLIARDI, E.; AVANZATI, A.M.; PAJORO, M.; NEGRI, I.; MARZORATI, M.; GONELLA, E.; ALMA, A.; DAFFONCHIO, D.;

BANDI, C. Multiple symbiosis in the leafhopper Scaphoideus titanus (Hemiptera: Cicadellidae): details of transovarial transmission of Cardinium sp. and yeast-like endosymbionts. Tissue \& Cell, Edinburgh, v. 40, n. 4, p. 231-242, 2008.

SANDER, K. Pattern formation in insect embryogenesis: the evolution of concepts and mechanisms. International Journal of Insect Morphology and Embryology, Oxon, v. 25, n. 4, p. 349-367, 1997.

SANDER, K.; GUTZEIT, H.O.; JÄCKLE, H. Insect embryogenesis: morphology, physiology, genetical and molecular aspects. In: KERKUT, G.A.; GILBERT, L.I. (Ed.). Comprehensive insect physiology, biochemistry and pharmacology. Oxford: Pergamon Press, 1985. p. 319-385.

SCHWALM, F.E. Arthropods: the insects. In: GILBERT, S.F.; RAUNIO, A.M. (Ed.). Embryology: constructing the organism. Massachusetts: Sinauer Associates, 1997. p. 259278.

SCHWEMMLER, W. Endosymbionts: factors of egg pattern formation. Journal of Insect Physiology, Oxford, v. 20, n. 8, p. 1467-1474, 1974.

SLOAN, D. B.; MORAN, N. A. Genome reduction and co-evolution between the primary and secondary bacterial symbionts of psyllids. Molecular Biology and Evolution, Oxford, v. 29, n. 12, p. 3781-92, 2012.

STERN, C.D. Gastrulation: from cells to embryo. New York: Cold Spring Harbor Laboratory Press, 2004. 721p. 
SUBANDIYAH, S.; NIKOH, N.; TSUYUMU, S.; SOMOWIYARJO, S.; FUKATSU, T. Complex endosymbiotic microbiota of the citrus psyllid Diaphorina citri (Homoptera: Psylloidea). Zoological Science, Tokyo, v. 17, n. 7, p. 983-989, 2000.

SZKLARZEWICZ, T.; MOSKAL, A. Ultrastructure, distribution, and transmission of endosymbionts in the whitefly Aleurochiton aceris Modeer (Insecta, Hemiptera, Aleyrodinea). Protoplasma, Viena, v. 218, n. 1, p. 45-53, 2001.

SZKLARZEWICZ, T.; KEDRA, K.; NIZNIK, S. Ultrastructure and transovarial transmission of endosymbiotic microorganisms in Palaeococcus fuscipennis (Burmeister) (Insecta, Hemiptera, Coccinea: Monophlebidae). Folia Biologica, Praga, v. 54, n. 2, p. 69-74, 2006.

TEIXEIRA, D.C.; WULFF, N.A.; LOPES, S.A.; YAMAMOTO, P.T.; MIRANDA, M.P.; SPÓSITO, M.B.; BELASQUE-JÚNIOR, J.; BASSANEZI, R.B. Caracterização e etiologia das bactérias associadas ao huanglongbing. Citrus Research \& Technology, Cordeirópolis, v. 31, n. 2, p. 115-128, 2010.

THAO, M.L.; MORAN, N.A.; ABBOT, P.; BRENNAN, E.B.; BURCKHARDT, D.H.; BAUMANN, P. Cospeciation of psyllids and their primary prokaryotic endosymbionts. Applied and Environmental Microbiology, Washington, v. 66, n. 7, p. 2898-905, 2000.

TSUCHIDA, T.; KOGA, R.; FUKATSU, T. Host plant specialization governed by facultative symbiont. Science, Washington, v. 303, n. 5666, p. 1989, 2004.

YAMAMOTO, P.T.; PAIVA, P.E.B.; GRAVENA, S. Flutuação populacional de Diaphorina citri Kuwayama (Hemiptera: Psyllidae) em pomares de citros na região Norte do Estado de São Paulo. Neotropical Entomology, Londrina, v. 30, n. 1, p. 165-170, 2001.

ŻELAZOWSKA, M.; BILIŃSKI, S.M. Distribution and transmission of endosymbiotic microorganisms in the oocytes of the pig louse, Haematopinus suis (L.) (Insecta:

Phthiraptera). Protoplasma, Viena, v. 209, n. 3/4, p. 207-213, 1999. 


\section{MORFOGÊNESE DO BACTERIOMA DURANTE O DESENVOLVIMENTO EMBRIONÁRIO DE Diaphorina citri (HEMIPTERA, LIVIIDAE)}

\section{Resumo}

Diaphorina citri complementa os nutrientes de sua dieta natural com nutrientes essenciais produzidos por bactérias mutualistas (simbiontes) presentes no bacterioma, a $\gamma$ Proteobacteria Carsonella e a $\beta$-Proteobacteria denominada Profftella. Essas bactérias são transmitidas transovarianamente, assumindo distribuição peculiar durante a embriogênese do hospedeiro, quando ocorre sua celularização e posterior formação do bacterioma. Neste trabalho, os eventos relacionados à formação do bacterioma durante a embriogênese de $D$. citri são descritos por meio de estudos de histologia e marcação com sondas oligonucleotídicas específicas para a detecção dos simbiontes do bacterioma. Nas primeiras etapas da embriogênese, as bactérias estão localizadas em uma massa na extremidade posterior do ovo, circundada por um halo citoplasmático. Células do hospedeiro se aderem a esta massa no início da blastulação, formando um revestimento delgado que precede à celularização dos simbiontes (formação dos bacteriócitos). Os bacteriócitos do bacterioma transitório resultante se posicionam, cada qual com um dos simbiontes associados ao inseto, de forma invertida àquela observada no bacterioma maduro, ou seja, com o simbionte Profftella localizado externamente a Carsonella. Durante as etapas seguintes do desenvolvimento embrionário, há a redistribuição dos bacteriócitos no bacterioma, e o sincício é formado, o que implica no rompimento das membranas dos bacteriócitos que contêm o simbionte Profftella, sendo este simbionte envolto por uma camada de bacteriócitos contendo Carsonella. A movimentação de inversão do embrião (catatrepsis) provoca o deslocamento do bacterioma para a região abdominal do embrião. Ao final da embriogênese, o bacterioma passa a apresentar formato trilobado observado nas fases ninfal e adulta.

Palavras-chave: Bacterioma; Desenvolvimento embrionário; Morfogênese; Psilídeo dos citros; Simbiontes 


\begin{abstract}
Diaphorina citri supplements its natural diet with essential nutrients provided by bacteriome-harbored mutualist bacteria (symbionts), the $\gamma$-Proteobacteria Carsonella and the $\beta$-Proteobacteria Profftella. These bacteria are transmitted transovarially, assuming a particular distribution during host embryogenesis, when they go through initial cellularization and bacteriome morphogenesis. We describe in here the main events related to bacteriome formation during $D$. citri embryogenesis by using histological and in situ hybridization analysis with symbiont-specific oligonucleotide probes. Symbiotic bacteria are at the posterior end of the egg early in the embryogenesis, where they are aggregated in a symbiont-ball surrounded by a cytoplasmic halo. During early blastulation, host cells adhere to the bacterial mass forming a thin cell envelope that precedes the formation of bacteriocytes. Bacteriocytes of the resulting transient bacteriome, each one containg one of the bacterial symbiont types, assume a distribution opposite of that observed in the mature bacteriome, with the syncytium symbiont (Profftella) located on the outside, around Carsonella. During the subsequent stages of the embryonic development, the bacteriocytes are rearranged and are followed by the rupture of the cell membrane of the bacteriocytes and release of the syncytium symbiont into the syncytium. The syncytium is surrounded by a layer of bacteriocytes harboring Carsonella, leading to the establishment of the bacteriome. Soon after katatrepsis, the bacteriome is moved to the embryo abdominal region, and the bacteriome assume its trilobate shape as observed in mature bacteriomes.
\end{abstract}

Keywords: Asian citrus psyllid; Bacteriome; Embryo development; Morphogenesis; Symbionts

\title{
3.1 Introdução
}

As associações de mutualismo entre insetos e micro-organismos são comuns na natureza, sendo ampla e altamente desenvolvidas em Hemiptera, principalmente aqueles pertencentes à subordem Sternorrhyncha (BUCHNER, 1965; DOUGLAS, 1989, 2011). Esses insetos alimentam-se de seiva, dieta deficitária em nutrientes, estando relacionada como um dos fatores propulsores do estabelecimento e manutenção das associações de simbiose fundamentadas na complementação da capacidade metabólica limitada do hospedeiro, frente à versatilidade bioquímica de micro-organismo(s) simbionte(s) (DOUGLAS, 1989, 2011; FELDHAAR, 2011). Os endossimbiontes contribuem com o hospedeiro via síntese de nutrientes essenciais e reciclagem de compostos nitrogenados, podendo ainda conferir maior tolerância ao estresse térmico, entre outras contribuições metabólicas que auxiliam o sucesso ecológico e evolutivo do inseto hospedeiro (BUCHNER, 1965; DOUGLAS, 1989, 2011; TSUCHIDA; KOGA; FUKATSU, 2004; OLIVER; MORAN; HUNTER, 2005; SHIGENOBU; WILSON, 2011; SHIGENOBU; STERN, 2012). 
A ocorrência de múltiplas bactérias endossimbiontes no mesmo inseto hospedeiro é comum em muitas espécies, incluindo a maioria dos psilídeos (BUCHNER, 1965; FUKATSU; NIKOH, 1998; KONO et al., 2008; SLOAN; MORAN, 2012). Simbiontes primários são normalmente restritos aos bacteriócitos e caracterizados pela interação obrigatória com o hospedeiro, resultado do processo evolutivo de transmissão vertical e coespeciação (SPAULDING; VON DOHLEN, 1998; BAUMANN, 2005; SLOAN; MORAN, 2012). Há também simbiontes associados ao bacterioma que se restringem ao tecido sincicial, revestido por bacteriócitos, que estabeleceram relações mais recentes com seus hospedeiros quando comparados àqueles abrigados em bacteriócitos. Os simbiontes do sincício estabelecem, muitas vezes, associações secundárias ou facultativas, mas estudos de genômica funcional de micro-organismos que habitam o bacterioma tem demonstrado, em inúmeros casos, que estes simbiontes do sincício assumem papel complementar aos simbiontes primários, aqueles associados aos bacteriócitos. Sendo assim, os mesmos também podem assumir a condição de simbiontes primários, visto que são essenciais para o suprimento dos nutrientes exigidos pelo hospedeiro (WILKINSON; KOGA; FUKATSU, 2007; SLOAN; MORAN, 2012; SU; ZHOU; ZHANG, 2013).

A manutenção da associação com o hospedeiro pode ocorrer por transferência horizontal inter ou intraespecífica, ou por transmissão vertical, comumente transovariana (RUSSELL et al., 2003; BAUMANN, 2005; OLIVER et al., 2010; SLOAN; MORAN, 2012). Em psilídeos, além do simbionte primário, a $\gamma$-Proteobacteria Candidatus Carsonella ruddii (passará a ser referida apenas por Carsonella), que ocupa os bacteriócitos, frequentemente ocorre um segundo endossimbionte associado ao sincício do bacterioma, a $\beta$-Proteobacteria denominada Candidatus Profftella armatura (FUKATSU; NIKOH, 1998; SUBANDIYAH et al., 2000; SLOAN; MORAN, 2012; NAKABACHI et al., 2013). Assim como mencionado, existem evidências genômicas de que os simbiontes de Enterobacteriaceae associados ao sincício dos psilídeos Heteropsylla (Hemiptera: Psyllidae) e Ctenarytaina eucalypti (Hemiptera: Aphalaridae), possuem longa história evolutiva com o hospedeiro. Esses simbiontes são transmitidos verticalmente e estabeleceram relação obrigatória com seus hospedeiros, sendo complementares ao metabolismo destes organismos (SLOAN; MORAN, 2012).

Ao longo do processo coevolutivo, inovações morfofisiológicas foram desenvolvidas a fim de garantir a estabilidade das interações de simbiose, bem como o controle sobre os micro-organismos simbiontes por parte do hospedeiro. Dessa forma, a transmissão transovariana é o mecanismo de transmissão de endossimbiontes à prole, comumente 
utilizado por Sternorrhyncha (BUCHNER, 1965; MIURA et al., 2003; BAUMANN, 2005). Durante o processo de transmissão, simbiontes intracelulares podem ser submetidos, isoladamente ou agregados, a estágios extracelulares, antes de atingirem finalmente as células (bacteriócitos) ou tecidos especializados (bacterioma) em abrigá-los (BUCHNER, 1965; MIURA et al., 2003; BAUMANN, 2005). A distribuição de simbiontes no ovo imediatamente após a transferência materna é variável, mas é comum a formação de aglomerados bacterianos na região posterior do ovo (LAUDANI et al., 1995; SZKLARZEWICZ; MOSKAL, 2001; MIURA et al., 2003). Tal distribuição, bem como a movimentação de simbiontes durante o desenvolvimento embrionário do hospedeiro, podem estar sob influência de fatores de controle do hospedeiro, como processos de contração do vitelo e delimitação por filamentos de actina (LAMB; HINDE, 1967; LAMBIASE et al., 1997; MIURA et al., 2003; SACCHI et al., 1985, 1998), os quais podem ser complementados por fagocitose (SACCHI et al., 1998) e, possivelmente, fatores humorais (GORMAN; KANKANALA; KANOST, 2004; FRAUNE; AUGUSTIN; BOSCH, 2011).

Diversas funções são atribuídas aos vitelófagos durante o desenvolvimento embrionário, tais como a contração do vitelo em decorrência de sua digestão, síntese de ácidos nucléicos e proteínas, fagocitose e formação de bacteriócitos (BUCHNER, 1965; COUNCE, 1961; KORNER, 1969; LAUDANI et al., 1995; BRAENDLE et al., 2003). Mecanismos distintos de internalização de simbiontes ocorrem entre formas sexuadas e partenogenéticas do pulgão Acyrthosiphon pisum (Hemiptera: Aphidade). Em embriões de formas sexuadas, os bacteriócitos são formados a partir de vitelófagos que invadem a massa de simbiontes durante a anatrepsis. Porém, comportamento distinto é descrito em embriões partenogenéticos, nos quais bactérias invadem o embrião durante o período de blástula, através de um duto formado por células foliculares (BRAENDLE et al., 2003; MIURA et al., 2003). Segundo Buchner (1965), em Psylla alni (Hemiptera: Psyllidae), vitelófagos invadem a massa de simbiontes no polo posterior do ovo durante a fase de blástula, sendo infectados gradualmente pelos simbiontes do bacterioma, antes da formação dessa estrutura. Os mecanismos envolvidos na formação do bacterioma nesta espécie envolvem a transferência seletiva de simbiontes para os vitelófagos formadores dos bacteriócitos e do sincício do bacterioma, sendo que os núcleos provisórios do sincício passam por um período de intensa multiplicação (BUCHNER, 1965).

A formação do bacterioma parece ocorrer mesmo quando os simbiontes são eliminados experimentalmente (SCHWEMMLER, 1974) ou perdidos durante o processo evolutivo (BRAENDLE et al., 2003). Dessa forma, as supostas funções fisiológicas desses 
micro-organismos durante a embriogênese permanecem obscuras, apesar de serem, por exemplo, necessários ao desenvolvimento normal do embrião de Euscelis plebejus (Hemiptera: Cicadellidae) (SCHWEMMLER, 1974).

Apesar de fundamentais na biologia de psilídeos (NAKABACHI et al., 2006; SLOAN; MORAN, 2012), nada consta na literatura sobre o comportamento dos simbiontes do bacterioma de $D$. citri durante as fases do desenvolvimento embrionário. Sendo assim, o foco deste trabalho foi caracterizar a distribuição desses simbiontes no ovo ao longo da formação do bacterioma de $D$. citri durante a embriogênese.

\subsection{Material e métodos}

\subsubsection{Manutenção dos insetos}

Os insetos utilizados nos experimentos foram provenientes de população de Diaphorina citri mantida no Laboratório de Interações em Insetos - ESALQ/USP, em condições controladas $\left(28 \pm 2^{\circ} \mathrm{C}, 60 \pm 10 \% \mathrm{UR}\right.$, fotofase $\left.14 \mathrm{~h}\right)$, utilizando-se de mudas de murta, Murraya exotica (Rutaceae), como substrato de criação (NAVA et al., 2007).

\subsubsection{Obtenção de ovos}

Adultos de D. citri com 3-5 dias de idade foram separados por sexo (DOSSI; CÔNSOLI, 2010) e mantidos (proporção 1q: $1 \delta^{\Uparrow}$ ) em gaiolas de polietileno (dimensões 08 $\mathrm{cm}$ diâmetro x $10 \mathrm{~cm}$ altura) para acasalamento durante $24 \mathrm{~h}$. Após esse período, os adultos foram transferidos para novas plantas, e os ovos coletados a intervalos de $4 \mathrm{~h}$, procedendo-se à fixação a intervalos de $8 \mathrm{~h}$, de acordo com a análise subsequente, de modo a abranger todo o período de desenvolvimento embrionário (cerca de 3,5 dias nas condições descritas acima). Os ovos coletados foram removidos da planta em solução de Ringer tamponada para insetos (3 $\mathrm{m} M \mathrm{CaCl}_{2} \cdot 2 \mathrm{H}_{2} \mathrm{O}, 182 \mathrm{~m} M \mathrm{KCl}, 46 \mathrm{~m} M \mathrm{NaCl}, 10 \mathrm{~m} M$ Tris base, pH 7,2) (CSH PROTOCOLS, 2007), sob microscópio estereoscópico Motic SMZ-168. Logo após a extração, os ovos foram transferidos imediatamente para a solução fixadora condizente ao tratamento subsequente e mantidos a $4^{\circ} \mathrm{C}$ até seu processamento. 


\subsubsection{Preparação de embriões para análise em montagem total}

Ovos de D. citri, previamente fixados em Carnoy (etanol: clorofórmio: ácido acético; 6:3:1) (KOGA et al., 2009), foram lavados em PBS-Tw (tampão fostato pH 7,2 + 1\% Tween 20) e transferidos para heptano (10 min) sob agitação. Em seguida, o material foi lavado em metanol absoluto $(2 x-5 \mathrm{~min})$ e $70 \%$ etanol $(2 \mathrm{x}-5 \mathrm{~min})$. Posteriormente, os ovos foram reidratados em água destilada $\left(\mathrm{d}-\mathrm{H}_{2} \mathrm{O}\right)(2 \mathrm{x}-5 \mathrm{~min})$, tratados com $2,5 \mathrm{~N} \mathrm{HCl}\left(13\right.$ min a $\left.60^{\circ} \mathrm{C}\right)$ e lavados rapidamente em água destilada $\left(\mathrm{d}-\mathrm{H}_{2} \mathrm{O}\right)$, antes de serem transferidos para o reativo de Schiff (35 min) em câmara escura. Na sequência, o material foi lavado rapidamente em d$\mathrm{H}_{2} \mathrm{O}$ e desidratado em série crescente de etanol $(70 \%, 96 \%, 2 \mathrm{x}-5 \mathrm{~min} / \mathrm{cada}$, e $100 \%, 3 \mathrm{x}-5$ min) e transferido para a solução (1:1) de etanol:"Benz mix" (mistura de 4:1 benzoato de benzila: álcool benzílico) (WIGAND; BUCHER; KLINGER, 1998) (15 min, sob agitação), Benz mix (overnight, sob agitação) e Benz mix:Entelan (1:1) (overnight), antes da montagem em lâmina e lamínula em Entelan ${ }^{\circledR}$ (Merck). As análises e o registro fotográfico foram realizados em microscópio de luz Zeiss Axiostar Plus, equipado com sistema de captura de imagens digital.

\subsubsection{Preparação de ovos embrionados para análise histológica}

Ovos previamente fixados em solução PFA-TBS (5\% paraformaldeído, 1\% Tween20, em $0,1 \%$ tampão fosfato, $\mathrm{pH} 7,2)$ por $24 \mathrm{~h}$, foram lavados no mesmo tampão ( $3 \mathrm{x}-10 \mathrm{~min}) \mathrm{e}$ desidratados em concentrações crescentes de etanol (1x - 30\%, 50\%, 70\% e 96\%, 3x - 100\% $10 \mathrm{~min} / \mathrm{cada}$ ). Em seguida, as amostras foram infiltradas em solução de historresina-etanol absoluto (3:1) por $24 \mathrm{~h}$, historresina-etanol absoluto (1:1) por $24 \mathrm{~h}$, historresina-etanol absoluto (1:2) por $24 \mathrm{~h}$, e historresina pura por $24 \mathrm{~h}$ a $4^{\circ} \mathrm{C}$. Logo após, os ovos foram transferidos para formas específicas contendo historresina pura (solução de inclusão) (Leica Historesin ${ }^{\circledR}$ ), permitindo-se a polimerização da historresina a temperatura ambiente durante 72 h. Cortes semi-finos (1-4 $\mu \mathrm{m})$ foram obtidos em ultra-micrótomo Leica Ultracut UCT e corados em solução aquosa de azul de toluidina (1\% azul de toluidina, $1 \%$ borato de sódio, p/v) ou Azan Heidenhain-Mallory (0,5\% azul de anilina, $1 \%$ laranja G, 3\% fucsina ácida, $1 \%$ ácido fosfotúngstico, p/v) (BEHMER et al., 2003) por 1 min. Após a coloração, os cortes foram rapidamente lavados em água destilada a fim de se retirar o excesso de corante, para posterior secagem a $60^{\circ} \mathrm{C}$ por 20 min, antes da montagem em lâmina e lamínula em Entelan ${ }^{\circledR}$ 
(Merck). A análise e o registro fotográfico do material processado foram realizados em microscópio de luz Zeiss Axiostar equipado com câmera para captura de imagens.

\subsubsection{Processamento de amostras para hibridação in situ e análise por microscopia de fluorescência (FISH)}

Ovos previamente fixados em etanol absoluto por $24 \mathrm{~h}$ foram removidos da planta em solução Ringer $\left(3 \mathrm{~m} M \mathrm{CaCl}_{2} .2 \mathrm{H}_{2} \mathrm{O}, 182 \mathrm{~m} M \mathrm{KCl}, 46 \mathrm{~m} M \mathrm{NaCl}, 10 \mathrm{~m} M\right.$ Tris base, pH 7,2) (CSH PROTOCOLS, 2007), e lavados (3x - 20 min) em tampão de hibridação (HB) (20 mM Tris- $\mathrm{HCl} \mathrm{pH} 8,0 ; 900 \mathrm{mM} \mathrm{NaCl} ; 0,01 \%$ SDS p/v; 30\% formamida v/v) (AMMAR; SHATTERS; HALL, 2011). Em seguida, foram incubados com 20 ng de sonda (concentração final) em tampão de hibridação a $46^{\circ} \mathrm{C}$ durante $12 \mathrm{~h}$, protegidos da luz. Logo após, as amostras foram lavadas (3x - 20 min) em tampão adstringente (20 mM Tris- $\mathrm{HCl}$ pH 7,4; 150 mM NaCl) (AMMAR; SHATTERS; HALL, 2011) a $48^{\circ} \mathrm{C}$, para a remoção de ligações inespecíficas, sendo submetidas à coloração de contraste com $1 \mu \mathrm{M}$ DAPI ou $3 \mathrm{nM}$ iodeto de propídio durante $5 \mathrm{~min}$. Em seguida, as amostras foram novamente lavadas em tampão adstringente antecedendo à montagem em lâmina e lamínula com solução anti-fade SlowFade (Invitrogen). As análises foram realizadas em microscópio epifluorescente Zeiss Imager M2, equipado com filtros apropriados.

As seguintes sondas, com seus respectivos fluoróforos, foram utilizadas em associação ao protocolo anteriormente descrito para detecção de simbiontes: EUB338: TAMRAGCTGCCTCCCGTAGGGAGT (19 bases); DC16SMyc: Alexa488-AACTTTTTGTATTACT CATT (20 bases); DC16SSyn: Alexa555-GACCCTCTGTATGCACCATT (20 bases). As sondas foram ressuspendidas em TE (10 mM Tris- $\mathrm{HCl} \mathrm{pH} 8,0 ; 1 \mathrm{mM}$ EDTA) estéril a 200 ng/ $\mu \mathrm{L}$ e diluídas a 20 ng no tampão de hibridação durante a preparação das amostras para incubação.

\subsection{Resultados}

O desenvolvimento embrionário de Diaphorina citri tem duração de aproximadamente $84 \mathrm{~h}$ a $28^{\circ} \mathrm{C}$ (ver detalhes, no item 3.2.1). Logo após a oviposição, os endossimbiontes foram observados no polo posterior do ovo, agrupados em uma massa compacta de formato 
arredondado, circundada por um halo citoplasmático (Figuras 1a; 2a). Não foi observada multiplicação dos simbiontes na massa durante as etapas iniciais do desenvolvimento embrionário.
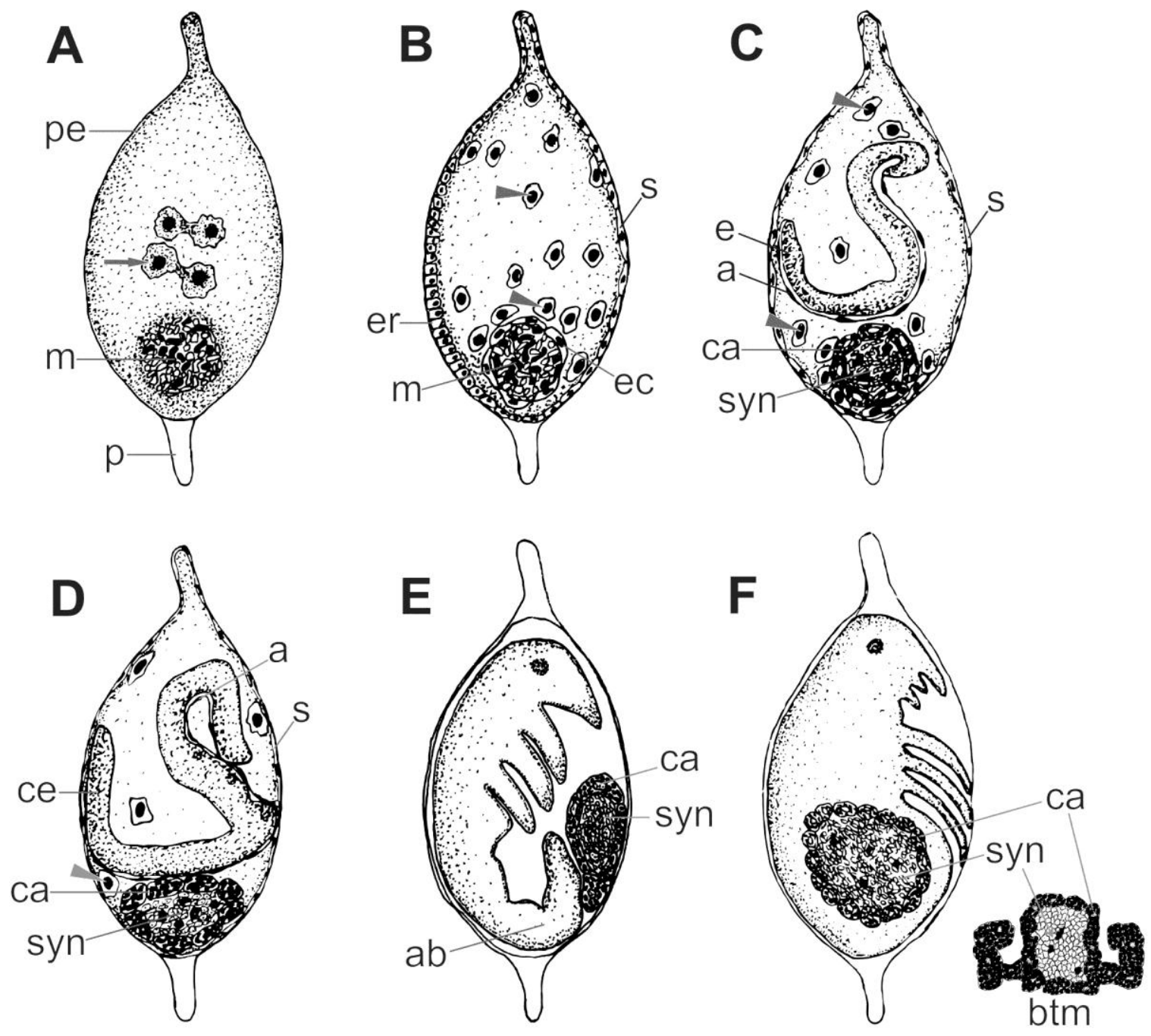

Figura 1 - Ilustração esquemática da morfogênese do bacterioma durante o desenvolvimento embrionário de Diaphorina citri (Hemiptera; Liviidae). Ovos voltados ventralmente para a esquerda. A, primeira hora após a oviposição, enérgidas (seta) e massa de simbiontes (m) no polo posterior do ovo; $\mathbf{B}$, final da fase de blástula (er) e formação da camada celular (ec) ao redor da massa de simbiontes (m); C, crescimento em extensão da banda germinativa (e) e formação dos bacteriócitos, os quais ficam posicionados de modo invertido no bacterioma transitório, caracterizado pela localização interna do simbionte Carsonella (ca), em relação aos bacteriócitos do simbionte Profftella (syn); D, segmentação da banda germinativa, indicando a posição da região cefálica (ce) e a reorganização dos bacteriócitos no bacterioma. Bacteriócitos com o simbionte Carsonella (ca) são reposicionados externamente, passando a revestir o simbionte Profftella (syn). E, final da catatrepsis, mostrando bacterioma deslocado de sua posição original no polo posterior, antes de ser reposicionado na região abdominal (ab) do embrião; F, desenvolvimento embrionário completado, bacterioma (btm) (em detalhe) localizado na cavidade abdominal, apresentando formato trilobado característico desta fase, em vista lateral (esquerda) e vista dorsal (inserto, à direita). Legenda: pe = periplasma; $\mathrm{p}=$ pedicelo; $\mathrm{s}$ $=$ serosa $; \mathrm{a}=$ membrana amniótica; cabeça de seta $=$ vitelófagos. 
O início das divisões nucleares e a migração de enérgidas foram observados a partir da primeira hora após a oviposição (AEL) (Figuras 1; 2a), e se estenderam durante as primeiras $10 \mathrm{~h}$ AEL, quando as enérgidas atingiram o periplasma para formar a blástula (Figuras 1; 3b). O processo de migração de enérgidas em $D$. citri ocorre de forma típica, sendo que esses núcleos sofrem espalhamento radial em direção à periferia do ovo em decorrência do processo de multiplicação durante o período pré-blástula ( 10h AEL).

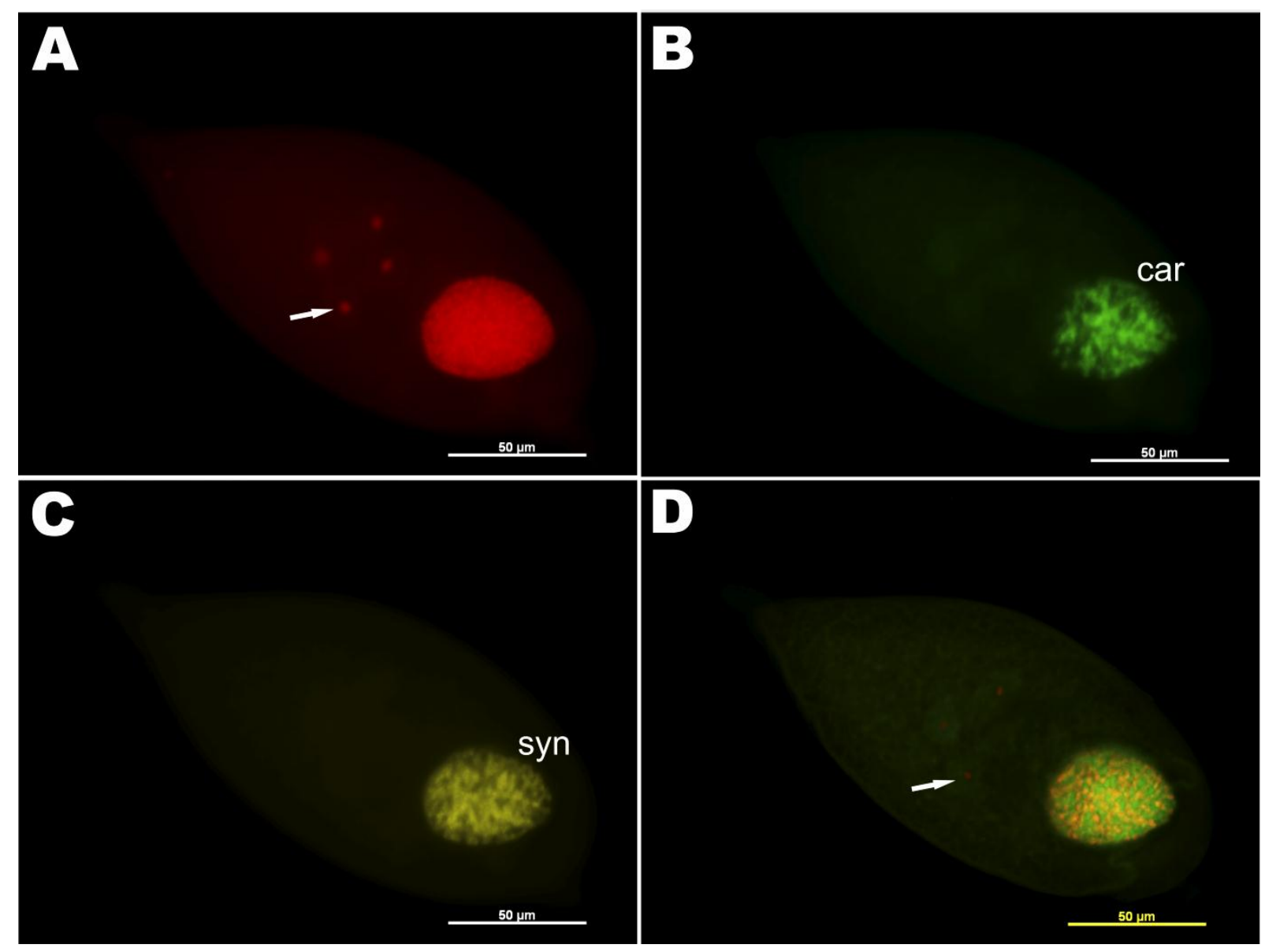

Figura 2 - Localização da massa de simbiontes na região posterior do ovo durante o início do desenvolvimento embrionário de Diaphorina citri (Hemiptera; Liviidae). Ovos com cerca de 1h após a oviposição, visualizados com a região anterior voltada à esquerda. A, enérgidas (seta) e massa de simbiontes; $\mathbf{B}$, simbionte primário Candidatus Carsonella ruddi (car), marcado na massa de simbiontes pela utilização de sonda oligonucleotídica específica para a região 16S rRNA; C, simbionte Profftella (syn) marcado na massa de simbiontes por meio de sonda específica para a região $16 \mathrm{~S}$ rRNA; D, sobreposição das imagens anteriores. Microscopia de epifluorescência; barras $=50 \mu \mathrm{m}$

Apesar do processo de migração de enérgidas nesta fase inicial da embriogênese, esses núcleos não foram observados associados à massa de bactérias. Porém, no início da formação da blástula, vitelófagos ficaram aderidos ao citoplasma que circunda a massa de simbiontes, 
formando uma camada de revestimento, observada até o final da fase de blástula (Figuras 1b; 3a-e). Nesse estágio do desenvolvimento embrionário, o bacterioma rudimentar se constitui em uma estrutura sincicial arredondada, já que ambos os simbiontes (Carsonella e Profftella) se mantém dispersos no citoplasma, numa condição muito parecida à distribuição original, verificada logo após a oviposição (Figura 3b, c, e).
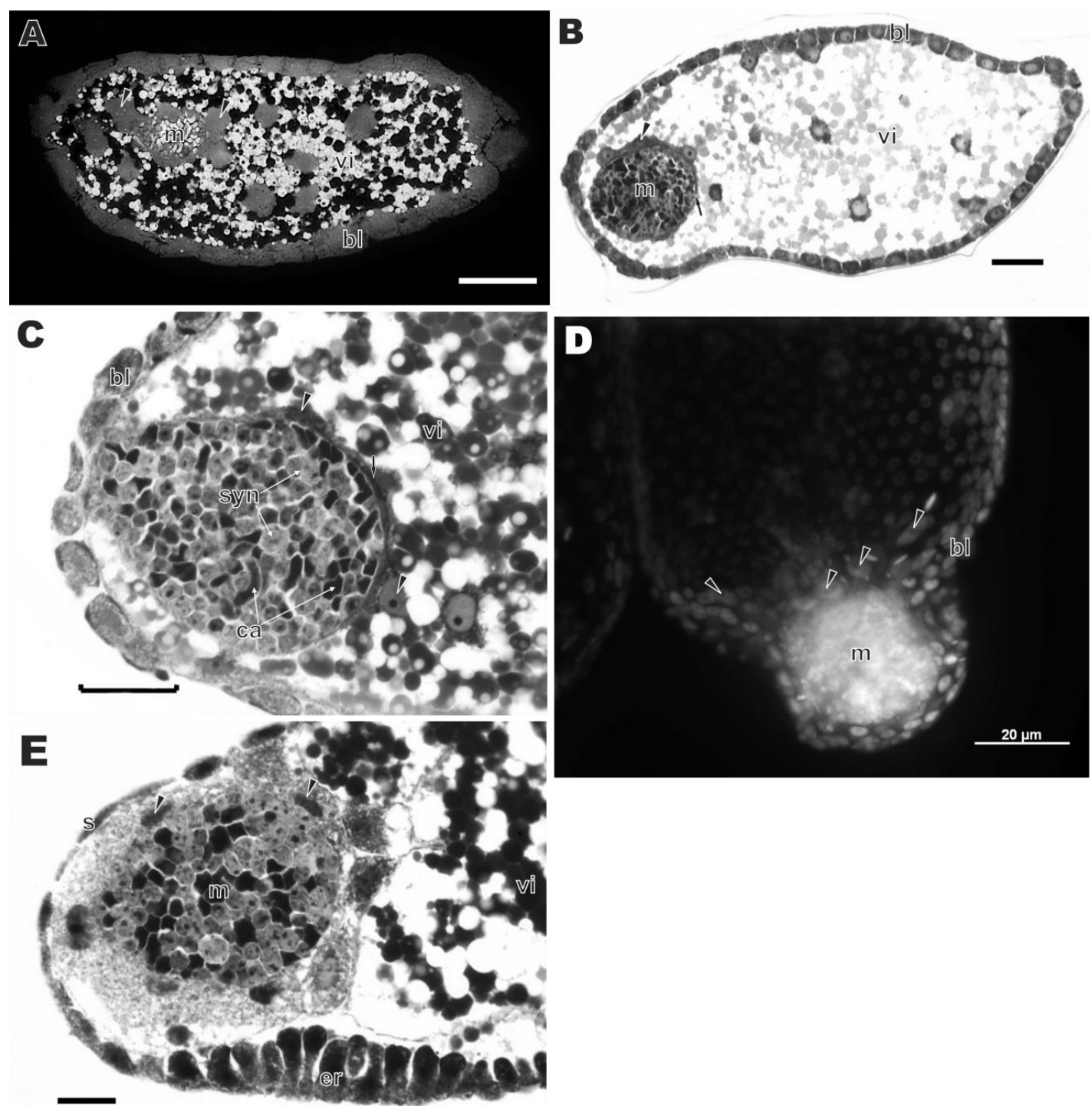

Figura 3 - Desenvolvimento embrionário e morfogênese do bacterioma de Diaphorina citri (Hemiptera; Liviidae). Ovos visualizados com a região posterior colocada à esquerda. A-B, ovos com cerca de 10h após a oviposição, durante a fase blástula (bl), mostrado vitelófagos (cabeça de seta) aderidos à massa de simbiontes (m); C, simbionte primário Candidatus Carsonella ruddi (ca), e o simbionte Ca. Profftella armatura (syn) distribuídos na massa de simbiontes, que apresenta vitelófagos (cabeça de seta) aderidos ao citoplasma circundante (seta) para formar durante a fase final de diferenciação da blástula (bl), D, uma camada de revestimento celular (cabeça de seta) ao redor da massa (m), localizada na região posterior do ovo, próximo ao embrião rudimentar (er) e em contato com a serosa (s). vi = vitelo. A, imagem tratada com o filtro "invert" do software Adobe Photoshop. A-C, E = Microscopia de luz, coloração Azul de toluidina; D = coloração com DAPI, microscopia de epifluorescência; barras $=20$ $\mu \mathrm{m}$ 
Esta condição foi observada até o estágio final de formação da blástula, quando ocorreu o adensamento de blastômeros na face posterior-ventral do embrião rudimentar e o início da gastrulação ( 10-16h AEL) (Figuras 3d-e; 4a). Vitelófagos se distribuíram por todo o deutoplasma, inclusive na periferia junto aos blastômeros. Ondas mitóticas foram observadas por microscopia de epifluorescência (montagem total de ovos fixados), na região circunvizinha da massa de simbiontes (região lateral-posterior do ovo), no estágio anterior ao adensamento da blástula. Neste mesmo período, vitelófagos presentes na região lateralposterior do ovo atingiram a massa de simbiontes, tendo sido observados em íntimo contato com as bactérias presentes na periferia da massa (Figura 4a).

Os simbiontes presentes na massa, observados por afinidade de coloração ou marcação por sondas oligonucleotídicas específicas, distribuíram-se de modo aleatório no interior da massa, organizando-se de tal modo a sugerir maior incidência de Profftella na periferia da massa de simbiontes (Figuras 2b-c; 3d; 4a-d). No final da fase de blástula, correspondente ao adensamento dos blastômeros na região ventral posterior para formar o embrião rudimentar, foi observado o início do processo de formação dos bacteriócitos.

Vitelófagos localizados na periferia da massa foram observados em associação às bactérias distribuídas na margem da massa de simbiontes, as quais foram sequestradas no citoplasma destas células (Figura 4a-c). A internalização do simbionte Carsonella ocorreu no interior da massa de bactérias por um grupo de vitelófagos que invadiu a massa. Como resultado do processo de infecção, observado no início da anatrepsis (Figura 4b, d), os bacteriócitos que continham o simbionte do sincício ficaram posicionados externamente àqueles que abrigavam Carsonella ( 16h AEL) (Figura 4c), configuração mantida durante a extensão da banda germinativa e início do estágio de segmentação ( 24h AEL) (Figura 4e-g).

O desenvolvimento do bacterioma ocorreu separado espacialmente da banda germinativa, próximo à membrana amniótica, na face ventral-posterior e junto à serosa da região posterior do ovo (Figura 4b-c, e).

Nas etapas seguintes do desenvolvimento embrionário, a partir da fase de segmentação ( 24h AEL), os bacteriócitos que continham Carsonella foram deslocados para a periferia do bacterioma, quando assumiam seu posicionamento definitivo, externamente aos bacteriócitos que continham o simbionte Profftella (Figuras 4f-i; 5b-c, f). Observações de imagens sequenciais dos eventos subsequentes do desenvolvimento embrionário sugerem que tenha ocorrido a fusão dos bacteriócitos que continham o simbionte do sincício para a formação do sincício, embora os mecanismos envolvidos ainda precisem ser elucidados. A partir desse 
estágio, o bacterioma passou a apresentar um epitélio delgado revestindo todo o órgão (Figura $4 \mathrm{i}$, inserto).
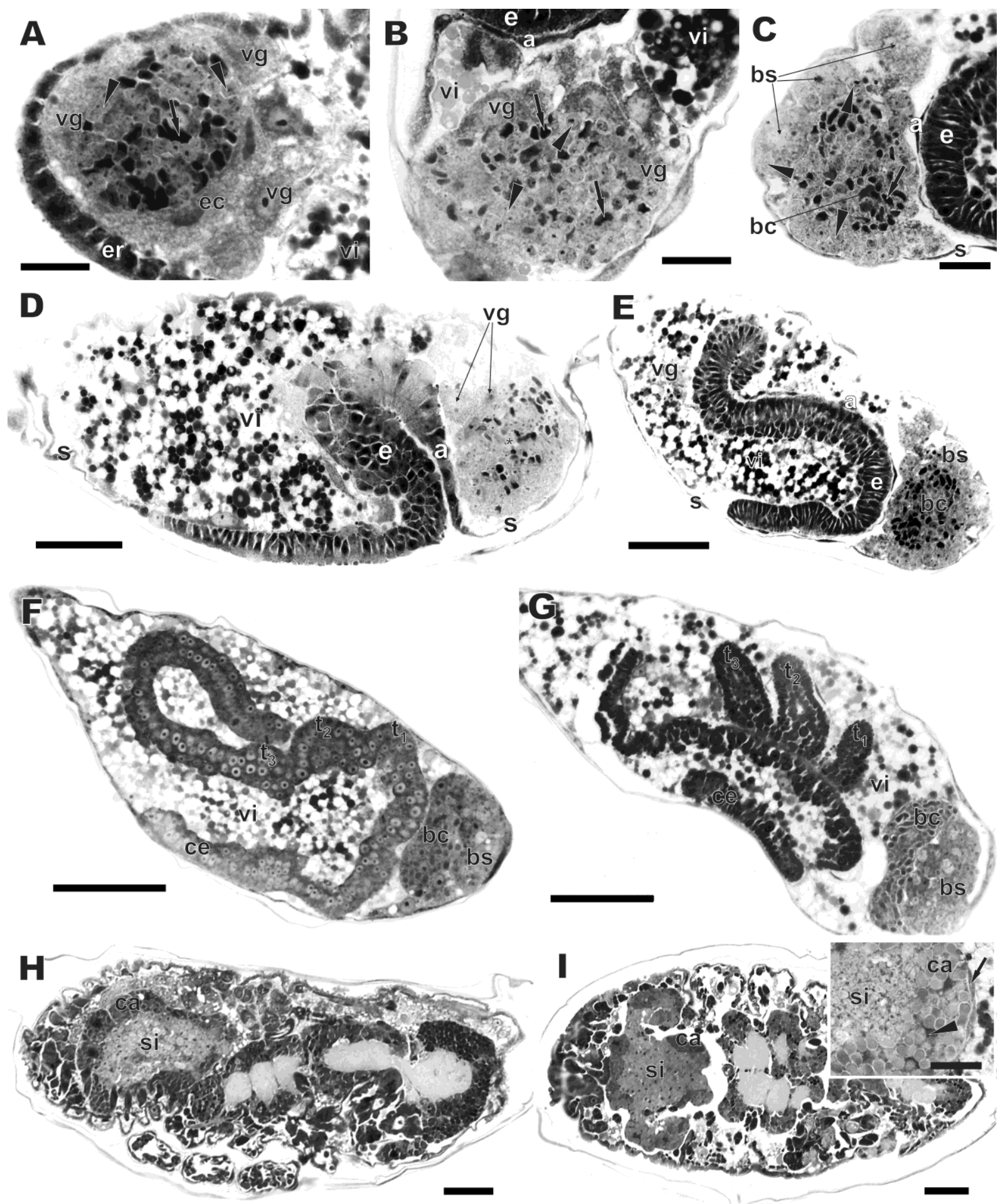
Figura 4 - Morfogênese do bacterioma durante o desenvolvimento embrionário de Diaphorina citri (Hemiptera; Liviidae). Ovos apresentam o bacterioma na região posterior. A, final do período de blástula e formação do embrião rudimentar (er), mostrando vitelófagos (vg) aderidos às células que revestem (ec) a massa de bactérias, na qual é possível observar os simbiontes Carsonella (seta) e Profftella (cabeça de seta); B e D, banda germinativa (e) durante a anatrepsis, mostrando a distribuição dos simbiontes Carsonella (seta) e Profftella (cabeça de seta) que está predominantemente na periferia da massa em contato com os vitelófgos (vg); C e E, crescimento em extensão da banda germinativa (e), observar bacteriócitos contendo o simbionte do sincício (bs) localizados na margem do bacterioma, externamente em relação àqueles que apresentam o simbionte Carsonella $(\mathrm{bc})$. Notar a presença de Profftella ainda presente no interior do bacterioma (cabeça de seta), indicando a incompletude do processo infectivo. Carsonella ocorre de modo agrupado ao redor do núcleo do respectivo bacteriócito (bc); $\mathbf{F}$ e $\mathbf{G}$, fase de segmentação e formação de apêndices na banda germinativa, com as regiões cefálica (ce) e torácica (segmentos $\mathrm{t}_{1}, \mathrm{t}_{2}, \mathrm{t}_{3}$ ) conspícuas. Bacterioma reorganizado, caracterizado pela presença dos bacteriócitos que abrigam Carsonella (bc) posicionados externamente aos de Profftella (bs); H e I, embriões de aprox. $72 \mathrm{~h}$ (corte sagital) e $80 \mathrm{~h}$ (corte coronal), com a região posterior colocada à esquerda, mostrando bacterioma de formato característico ao final da embriogênese, inserido na cavidade abdominal, contendo os simbiontes Carsonella (ca) e o simbionte do sincício (si); com detalhe do epitélio delgado de revestimento do bacterioma (inserto, seta) e núcleos dos bacteriócitos (inserto, cabeça de seta). $\mathrm{s}=$ serosa; $\mathrm{a}=$ âmnio; vi = vitelo. Figuras A-I, azul de toluidina; inserto, Feulgen; microscopia de luz. Barras $=20 \mu \mathrm{m}$.

O sincício, já diferenciado, foi observado na área central do bacterioma, em seguida à reorganização dos bacteriócitos, mas não foram obtidos detalhes desse evento ( $32 \mathrm{~h}$ AEL). Ao final da etapa de crescimento e diferenciação da banda germinativa ( $48 \mathrm{~h}$ AEL), o embrião realizou o segundo evento da blastocinese, a catatrepsis, invertendo seu posicionamento em relação ao eixo ântero-posterior e dorso-ventral do ovo. Durante a catatrepsis, a região cefálica originalmente colocada na região postero-ventral do ovo, passou à região anterior. Os movimentos decorrentes provocaram o rompimento da serosa, e o bacterioma foi deslocado para a região mediano-ventral do ovo, antes de ser reposicionado na região abdominal do embrião ao término da catatrepsis (Figuras 1e; 5d). Nas etapas finais do desenvolvimento embrionário, concomitantes ao término da organogênese, o formato arredondado do bacterioma predominante ao longo do desenvolvimento (Figura 4h), sofreu modificações ( 64h AEL), supostamente em função da adequação aos demais tecidos da cavidade abdominal, dentre os quais estão a musculatura dorso-ventral e intestino (Figura 4h, i), passando ao formato trilobado típico ( 72h AEL) (Figura 4i). Essa configuração é caracterizada pela presença de um lobo central desenvolvido e dois lobos menores, posicionados lateralmente, e se manteve até o final do desenvolvimento embrionário (cerca 80 - 84h AEL). 

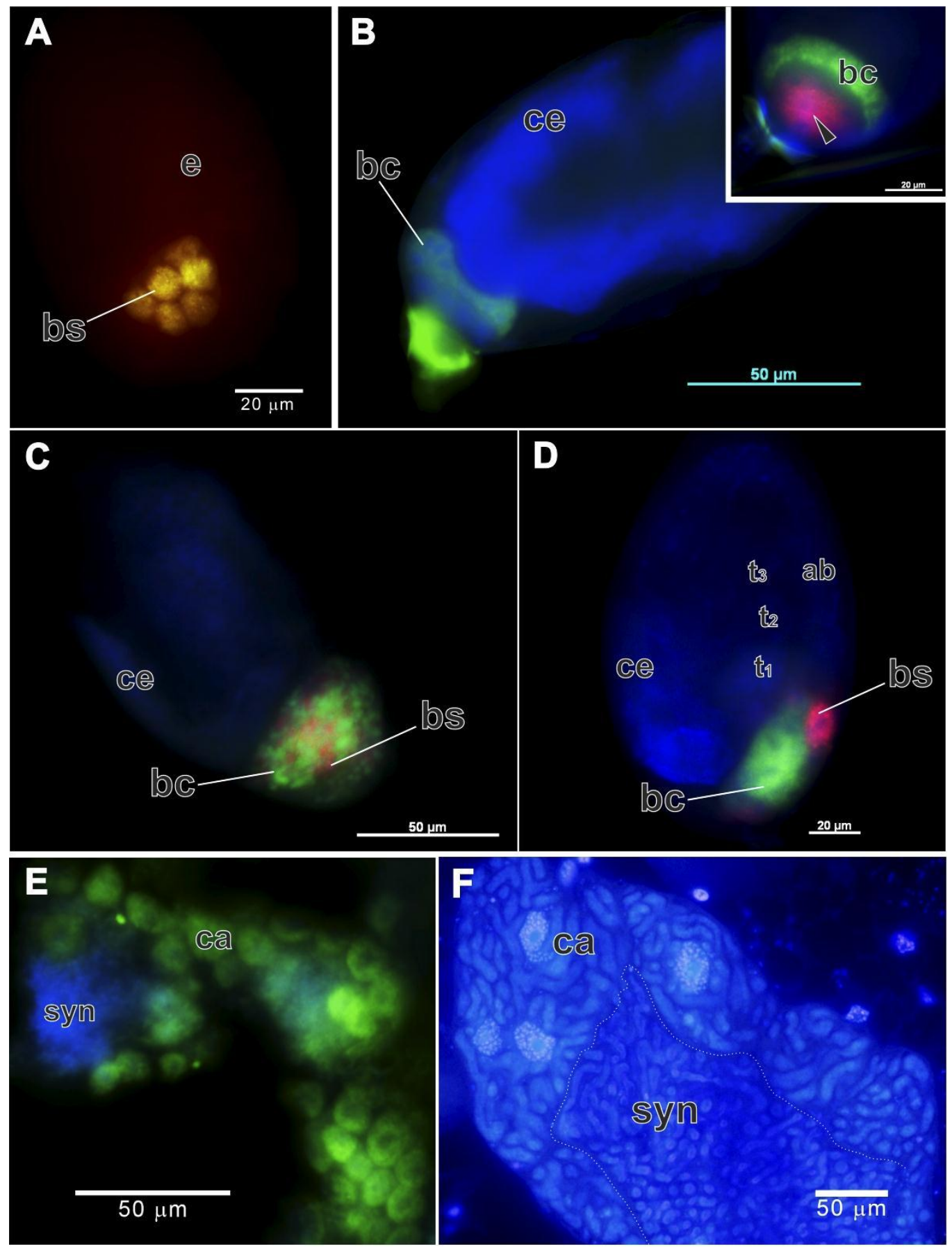

Figura 5 - Morfogênese do bacterioma de Diaphorina citri (Hemiptera; Liviidae). Bacterioma posicionado no polo posterior do ovo, salvo se informado. A, embrião (e) com cerca de $16 \mathrm{~h}$ de incubação, bacteriócitos logo após a infecção pelo simbionte Profftella (bs), marcado por sonda oligonucleotídica 16S rRNA específica; B-C, embrião em estágio de segmentação (cerca 24h) mostrando bacterioma contendo os bacteriócitos do simbionte Carsonella (bc) posicionados externamente ao simbionte Profftella (bs) (inserto, cabeça de seta); D, embrião com cerca de $48 \mathrm{~h}$ de incubação mostrando o bacterioma deslocado de sua posição original. O movimento do embrião causa deformação temporária, alterando a distribuição dos bacteriócitos de Carsonella (bc) e de Profftella (bs). E, vista parcial do bacterioma em montagem total mostrando os bacteriócitos do simbionte Carsonella (ca) marcados por sondas específicas (16S rRNA), e F, corte histológico do bacterioma em seu formato definitivo, corado com DAPI (3,4-diamidino-fenilindol) mostrando detalhes dos simbiontes Carsonella (ca) no interior de bacteriócitos, e Profftella (syn no citoplasma sincicial (área tracejada). ce $=$ região cefálica, apêndices toráricos $=\mathrm{t}_{1}, \mathrm{t}_{2}, \mathrm{t}_{3} ; \mathrm{ab}=$ região abdominal. Microscopia de epifluorescência; A e D, barras $=20 \mu \mathrm{m} ; \mathrm{B}, \mathrm{C}, \mathrm{E}, \mathrm{F}$, barras $=50 \mu \mathrm{m}$. 


\subsection{Discussão}

O posicionamento e a distribuição agrupada dos endossimbiontes de $D$. citri no deutoplasma da região posterior de ovos recém-depositados, parece ser um evento comum entre os membros de Hemiptera que transmitem seus simbiontes por via transovariana (BUCHNER, 1965; KORNER, 1972; SZKLARZEWICZ; MOSKAL, 2001; BRAENDLE et al., 2003; MIURA et al., 2003; SWIATONIOWSKA et al., 2012), o qual também é encontrado em espécies de Dictyoptera ( SACCHI et al., 1985, 1996, 1998; LAUDANI et al., 1995).

Enquanto a agregação dos simbiontes de Mastotermes darwiniensis (Isoptera: Mastotermitidae) se distribui em ambos os polos do ovo (SACCHI et al., 1998), em D. citri os agregados de simbiontes do bacterioma se localizam apenas no polo posterior. A organização e distribuição de simbiontes no período de pré-blástula (0-10h AEL) e de formação dos bacteriócitos (cerca de 10h AEL) que se segue pode ser auxiliada por elementos do citoesqueleto, visto o papel fundamental dos microtúbulos e microfilamentos de actina na formação de ilhas citoplasmáticas e na redistribuição de elementos citoplasmáticos (BRAENDLE et al., 2003; TRAM; FERREE; SULLIVAN, 2003; VENETI et al., 2004). Apesar da escassez de investigações nessa área, há registros que sugerem o envolvimento de elementos do citoesqueleto nesse processo, além de fatores genéticos do simbionte e do hospedeiro (CALLAINI; RIPARBELLI; DALLAI, 1994; VENETI et al., 2004; KOGA et al., 2012). Entretanto, essa hipótese precisa ser confirmada por experimentos de marcação específica dos componentes envolvidos e de ultraestrutura.

Em ovos do pulgão A. pisum, a alta concentração de microfilamentos de actina na região de distribuição dos simbiontes durante os eventos de transmissão, movimentação e formação dos bacteriócitos, sugere a ocorrência de barreira mecânica como fator de controle sobre a distribuição dos simbiontes (BRAENDLE et al., 2003; MIURA et al., 2003). Adicionalmente, a distribuição de Wolbachia durante a oogênese e embriogênese inicial de Drosophila, apesar de diferir entre linhagens distintas, apresenta padrões de distribuição relacionados à distribuição de morfógenos e associação ao citoesqueleto, podendo inclusive ocorrer às expensas de motores moleculares do hospedeiro (CALLAINI; RIPARBELLI; DALLAI, 1994; SERBUS; SULLIVAN, 2007; TRAM; FERREE; SULLIVAN, 2003; VENETI et al., 2004).

A distribuição de vitelófagos junto à massa de simbiontes durante a blastulação, colocando as bactérias da periferia da massa em íntimo contato com a camada celular, 
também foi relatada em Periplaneta americana (Blattodea: Blattidae) (LAUDANI ET AL. 1995), caracterizando uma estrutura que lembra um bacterioma rudimentar. Entretanto a formação de bacteriócitos é observada apenas no final da fase de blástula, quando ocorre a condensação dos blastômeros na região ventral e o início da gastrulação, posteriormente ao observado para outras espécies de insetos (KORNER, 1969, 1972). Além disso, a formação do revestimento ao redor da massa de simbiontes em $D$. citri precede a invasão da massa por vitelófagos e a captura gradual dos simbiontes, diferentemente do observado no desenvolvimento de bacteriócitos em A. pisum. Nesse caso, além da massa de simbiontes não ser revestida por epitélio celular, as células do hospedeiro invadem a massa de simbiontes durante a fase de blástula (embrião sexuado) para formar bacteriócitos primários (MIURA et al., 2003; KOGA et al., 2012).

O comportamento complexo de morfogênese observado para o bacterioma de D. citri, caracterizado pelo posicionamento invertido dos grupos de bacteriócitos, seguido de reorganização ao final do processo de formação, parece sem igual na literatura, exceto pela semelhança ao fenômeno descrito por Profft em sua descrição sobre a formação do bacterioma de P. alni (BUCHNER, 1965). De acordo com Braendle et al. (2003), a formação do bacterioma em A. pisum ocorre em duas etapas, sendo iniciada durante a fase de blástula, com invasão da massa de simbiontes por um primeiro grupo de bacteriócitos, e concluída ao final da etapa de crescimento da banda germinativa, quando novos bacteriócitos (recrutados tardiamente) migram e intercalam-se ao bacterioma original, formando o bacterioma definitivo. A reconfiguração do bacterioma de D. citri, a partir da reorganização dos bacteriócitos e formação do sincício, ocorre em períodos mais tardios.

Exceto pelo deslocamento temporário para a região mediana do ovo, o comportamento geral do bacterioma durante a catratrepsis em D. citri assemelha-se ao apresentado pelo pulgão $A$. pisum, no qual o posicionamento do bacterioma é pouco alterado durante a catatrepsis (MIURA et al., 2003).

Vários autores relatam a ocorrência de degeneração e redução da população de simbiontes durante o processo de morfogênese do bacterioma devido à atividade lisossomal, que pode ser mais evidente nos períodos finais do desenvolvimento embrionário, servindo como fonte de suprimento energético e/ou como forma de controle da população de simbiontes (HINDE, 1971; LAUDANI et al., 1995; SACCHI et al., 1996; NISHIKORI et al., 2009; KOGA et al., 2012). Tais eventos não foram observados em D. citri por meio de análises morfológicas. Adicionalmente, dados obtidos por PCR quantitativo em tempo real indicaram incremento na densidade de células dos simbiontes durante a morfogênese do 
bacterioma neste inseto (veja detalhes no item 4.3 do Capítulo 4). Entretanto, experimentos suplementares, como a utilização de marcadores citoquímicos que permitam acompanhar a atividade lisossomal durante os eventos relacionados, poderiam, de fato, revelar a ocorrência desse evento durante a embriogênese de $D$. citri, bem como os possíveis estágios de formação do bacterioma a que estariam relacionados.

As modificações na estrutura geral do bacterioma de $D$. citri ao final da embriogênese são descritas em várias espécies (BUCHNER, 1965) e presume-se que sejam filogeneticamente definidas em consideração às características morfofisiológicas de cada sistema de simbiose, além da delimitação espacial decorrente da formação dos demais tecidos e órgãos presentes na cavidade abdominal.

A complexidade dos fenômenos envolvidos na morfogênese do bacterioma de D. citri, principalmente durante o processo infectivo, e a redistribuição dos bacteriócitos durante a formação dessa estrutura, requer estudos subsequentes a fim de responder algumas questões, como 1) por que a massa de simbiontes é revestida por um epitélio, preliminarmente à formação dos bacteriócitos, 2) quais são os fatores envolvidos no recrutamento de vitelófagos envolvidos na internalização seletiva de simbiontes na massa, 3) quais os fatores citológicos e moleculares relacionados ao padrão de internalização seletiva observado para $D$. citri com foco nos simbiontes sua história evolutiva com o hospedeiro e, finalmente, 4) quais seriam os mecanismos envolvidos na redistribuição dos bacteriócitos para a reorganização do bacterioma.

\subsection{Conclusões}

- A formação dos bacteriócitos ocorre na fase de blástula.

- Os vitelófagos internalizam, de forma seletiva, as diferentes bactérias simbiontes, formando os bacteriócitos.

- Os simbiontes do bacterioma de D. citri apresentam distribuição invertida no início de sua morfogênese, em comparação àquela observada no bacterioma maduro.

- A massa de simbiontes permanece imóvel ao longo do desenvolvimento embrionário, a não ser durante a segunda etapa da blastocinese (catatrepsis), quando assume sua posição definitiva na cavidade abdominal.

- O bacterioma apresenta formato trilobado ao final da embriogênese. 


\section{Referências}

AMMAR, E.D.; SHATTERS, R.G.; HALL, D.G. Localization of Candidatus Liberibacter asiaticus, associated with citrus huanglongbing disease, in its psyllid vector using fluorescence in situ hybridization. Journal of Phytopathology, Malden, v. 159, n. 11/12, p. 726-734, 2011.

BAUMANN, P. Biology bacteriocyte-associated endosymbionts of plant sap-sucking insects. Annual Review of Microbiology, Palo Alto, v. 59, p. 155-89, 2005.

BEHMER, O.A.; TOLOSA, E.M.C.; FREITAS NETO, A.G.; RODRIGUES, C.J. Manual de técnicas para histologia normal e patológica. Barueri: Manole, 2003. 331p.

BRAENDLE, C.; MIURA, T.; BICKEL, R.; SHINGLETON, A.W.; KAMBHAMPATI, S.; STERN, D.L. Developmental origin and evolution of bacteriocytes in the aphid-Buchnera symbiosis. PLoS Biology, São Francisco, v. 1, n. 1, p. E21, 2003.

BUCHNER, P. Endosymbiosis of animals with plant microorganisms. New York: John Wiley, 1965. 909p.

CALLAINI, G.; RIPARBELLI, M.G.; DALLAI, R. The distribution of cytoplasmic bacteria in the early Drosophila embryo is mediated by astral microtubules. Journal of Cell Science, Cambridge, v. 107, p. 673-682, 1994.

COLD SPRINGER HARBOR PROTOCOLS. Drosophila ringer's solution. 2007.

Disponível em: <http://cshprotocols.cshlp.org/cgi/content/full/2007/7/pdb.rec10919>. Acesso em: 21 nov. 2008.

COUNCE, S.J. The analysis of insect embryogenesis. Annual Review of Entomology, Standford, v. 6, p. 295-312, 1961.

DOUGLAS, A.E. Mycetocyte symbiosis in insects. Biological Reviews of the Cambridge Philosophical Society, Cambridge, v. 64, n. 4, p. 409-34, 1989.

. Lessons from studying insect symbioses. Cell Host \& Microbe, Cambridge, v. 10, n. 4, p. 359-367, 2011.

DOSSI, F.C.A.; CÔNSOLI, F.L. Desenvolvimento ovariano e influência da cópula na maturação dos ovários de Diaphorina citri Kuwayama (Hemiptera: Psyllidae). Neotropical Entomology, v. 39, n. 3, p. 414-419, 2010.

FRAUNE, S.; AUGUSTIN, R.; BOSCH, T.C. Embryo protection in contemporary immunology: why bacteria matter. Communicative \& Integrative Biology, Austin, v. 4, n. 4, p. 369-372, 2011.

FUKATSU, T.; NIKOH, N. Two intracellular symbiotic bacteria from the mulberry psyllid Anomoneura mori (Insecta, Homoptera). Applied and Environmental Microbiology, Washington, v. 64, n. 10, p. 3599-3606, 1998. 
GORMAN, M.J.; KANKANALA, P.; KANOST, M.R. Bacterial challenge stimulates innate immune responses in extra-embryonic tissues of tobacco hornworm eggs. Insect Molecular Biology, Malden, v. 13, n. 1, p. 19-24, 2004.

HINDE, R. The control of the mycetome symbiotes of the aphids Brevicoryne brassicae, Myzus persicae, and Macrosiphum rosae. Journal of Insect Physiology, Oxford, v. 17, n. 9, p. 1791-1800, 1971.

HOUK, E.J.; GRIFFITHS, G.W. Intracellular symbiotes of the Homoptera. Annual Review of Entomology, Standford , v. 25, n. 1, p. 161-187, 1980.

KOGA, R.; MENG, X.Y.; TUSUCHIDA, T.; FUKATSU, T. Cellular mechanism for selective vertical transmission of an obligate insect symbiont at the bacteriocyte-embryo interface. Proceedings of the National Academy of Sciences of the United States of America, Washington, v. 109, n. 20, p. 1230-1237, 2012.

KONO, M.; KOGA, R.; SHIMADA, M.; FUKATSU, T. Infection dynamics of coexisting beta- and gammaproteobacteria in the nested endosymbiotic system of mealybugs. Applied and Environmental Microbiology, Washington, v. 74, n. 13, p. 4175-4184, 2008.

KORNER, H.K. Die embryonale Entwicklung der symbiontenführenden organe von Euscelis plebejus fall. (Homoptera-Cicadina) Oecologia, New York, v. 2, n. 3, p. 319-346, 1969.

Elektronenmikroskopische untersuchungen am embryonalen mycetom der kleinzikade Euscelis plebejus fall. (Homoptera, Cicadina). Zeitschrift Für Parasitenkunde, Berlin, v. 40, n. 3, p. 203-226, 1972.

On the host-symbiont-cycle of a leafhopper (Euscelis plebejus) endosymbiosis. Experientia, Berlin, v. 15, n. 4, p. 463-464, 1976.

KOSE, H.; KARR, T.L. Organization of Wolbachia pipientis in the Drosophila fertilized egg and embryo revealed by an anti-Wolbachia monoclonal antibody. Mechanisms of Development, Amsterdam, v. 51, n. 2/3, p. 275-88, 1995.

LAMB, K.P.; HINDE, R. Structure and development of the mycetome in the cabbage aphid, Brevicoryne brassicae. Journal of Invertebrate Pathology, Sandiego, v. 9, n. 1, p. 3-11, 1967.

LAMBIASE, S.; GRIGOLO, A.; LAUDANI, U.; SACCHI, L.; BACCETTI, B. Pattern of bacteriocyte formation in Periplaneta americana (L.) (Blattaria: Blattidae). International Journal of Insect Morphology and Embryology, Oxon, v. 26, n. 1, p. 9-19,1997.

LAUDANI, U.; GRIGOLO, A.; SACCHI, L.; CORONA, S.; BISCALDI, G. On the mycetome formation in Periplaneta americana (Blattaria, Blattidae). Italian Journal of Zoology, Padova, v. 62, n. 4, p. 345-351, 1995.

LEE, Y.H.; HOU, R.F. Physiological roles of a yeast-like symbiote in reproduction and embryonic development of the brown planthopper, Nilaparvata lugens Stål. Journal of Insect Physiology,Oxford, v. 33, n. 11, p. 851-860, 1987. 
MIURA, T.; BRAENDLE, C.; SHINGLETON, A.; SISK, G.; KAMBLAMPATI, S.; STERN, D.L. A comparison of parthenogenetic and sexual embryogenesis of the pea aphid Acyrthosiphon pisum (Hemiptera: Aphidoidea). Journal of Experimental Zoology Part B: Molecular and Developmental Evolution, Washington, v. 295, n. 1, p. 59-81, 2003.

NAKABACHI, A. YAMASHITA, A.; TOH, H.; ISHIKAWA, H.; DUNBAR, H.E.; MORAN, N.A.; HATTORI, M. The 160-kilobase genome of the bacterial endosymbiont Carsonella. Science, Washington, v. 314, n. 5797, p. 267, 2006.

NAKABACHI, A.; UEOKA, R.; OSHIMA, K.; TETA, R.; MANGONI, A.; GURGUI, M.; OLDHAM, N.J.; van ECHTEN-DECKERT, G.; OKAMURA, K.; YAMAMOTO, K.; INOUE, H.; OHKUMA, M.; HONGOH, Y.; MIYAGISHIMA, S.; HATTORI, M.; PIEL, J.; FUKATSU, T. Defensive bacteriome symbiont with a drastically reduced genome. Current Biology, Cambridge, v. 23, n. 15, p. 1478-1484, 2013.

NAVA, D.E.; TORRES, M.L.G.; RODRIGUES, M.D.L.; BENTO, J.M.S.; PARRA, J.R.P. Biology of Diaphorina citri (Hem. Psyllidae) on different hosts and at different temperatures. Journal of Applied Entomology, Malden, v. 131, n. 9, p. 709-715, 2007.

NISHIKORI, K.; MORIOKA, K.; KUBO, T.; MORIOKA, M. Age- and morph-dependent activation of the lysosomal system and Buchnera degradation in aphid endosymbiosis.

Journal of Insect Physiology, Oxford, v. 55, n. 4, p. 351-7, 2009.

OLIVER, K.M.; MORAN, N.A.; HUNTER, M.S. Variation in resistance to parasitism in aphids is due to symbionts not host genotype. Proceedings of the National Academy of Sciences of the United States of America, Washington, v. 102, n. 36, p. 12795-12800, 2005.

OLIVER, K.M.; DEGNAN, P.H.; BURKE, G.R.; MORAN, N.A. Facultative symbionts in aphids and the horizontal transfer of ecologically important traits. Annual Review of Entomology, Palo Alto, v. 55, p. 247-266, 2010.

RUSSELL, J.A.; LATORRE, A.; SABATER- MUNOZ, B.; MOVA, A.; MOYAN, N.A. Side-stepping secondary symbionts: widespread horizontal transfer across and beyond the Aphidoidea. Molecular Ecology, Malden, v. 12, n. 4, p. 1061-1075, 2003.

SACCHI, L.; GRIGOLO, A. Behavior of symbionts during oogenesis and early stages of development in the German cockroach, Blattella germanica (Blattodea). Journal of Invertebrate Pathology, Sandiego, v. 46, n. 2, p. 139-152, 1985.

SACCHI, L.; CORONA, S.; GRIGOLO, A.; LAUDANI, U.; SELMI, M.G.; BIGLIARD, E. The fate of the endocytobionts of Blattella germanica (Blattaria: Blattellidae) and Periplaneta americana (Blattaria: Blattidae) during embryo development. Italian Journal of Zoology, Padova, v. 63, n. 1, p. 1-11, 1996.

SACCHI, L.; NALEPA, C.A.; BIGLIARDI, E.; LENZ, M.; BANDI, C.; CORONA, S.; GRIGOLO, A.; LAMBIASE, S.; LAUDANI, U. Some aspects of intracellular symbiosis during embryo development of Mastotermes darwiniensis (Isoptera: Mastotermitidae).

Parassitologia, Roma, v. 40, n. 3, p. 309-16, 1998. 
SCHWEMMLER, W. Endosymbionts: factors of egg pattern formation. Journal of Insect Physiology, Oxford, v. 20, n. 8, p. 1467-1474, 1974.

SERBUS, L.R.; SULLIVAN, W. A cellular basis for Wolbachia recruitment to the host germline. PLoS Pathogens, São Francisco, v. 3, n. 12, p. e190, 2007.

SHIGENOBU, S.; STERN, D.L. Aphids evolved novel secreted proteins for symbiosis with bacterial endosymbiont. Proceedings of the Royal Society B: Biological Sciences, London, v. 280, n. 1750, p. 20121952, 2012.

SHIGENOBU, S.; WILSON, A.C.C. Genomic revelations of a mutualism: the pea aphid and its obligate bacterial symbiont. Cellular and Molecular Life Sciences, Basel, v. 68, n. 8, p. 1297-1309, 2011.

SLOAN, D.B.; MORAN, N.A. Genome reduction and co-evolution between the primary and secondary bacterial symbionts of psyllids. Molecular Biology and Evolution, Oxford, v. 29, n. 12, p. 3781-3792, 2012.

SPAULDING, A.W.; VON DOHLEN, C.D. Phylogenetic characterization and molecular evolution of bacterial endosymbionts in psyllids (Hemiptera: Sternorrhyncha). Molecular biology and evolution, Oxford, v. 15, n. 11, p. 1506-1513, 1998.

SUBANDIYAH, S.; NIKOH, N.; TSUYUMU, S.; SOMOWIYARJO, S.; FUKATSU, T. Complex endosymbiotic microbiota of the citrus psyllid Diaphorina citri (Homoptera: Psylloidea). Zoological Science, Tokyo, v. 17, n. 7, p. 983-989, 2000.

SWIATONIOWSKA, M.; OGORZALEK, A.; GOLAS, A.; MICHALIK, A.; SZKLARZEWICZ, T. Ultrastructure, distribution, and transovarial transmission of symbiotic microorganisms in Nysius ericae and Nithecus jacobaeae (Heteroptera: Lygaeidae:

Orsillinae). Protoplasma, Viena, v. 250, n. 1, p. 325-332, 2012.

SZKLARZEWICZ, T.; MOSKAL, A. Ultrastructure, distribution, and transmission of endosymbionts in the whitefly Aleurochiton aceris Modeer (Insecta, Hemiptera, Aleyrodinea). Protoplasma, Viena, v. 218, n. 1, p. 45-53, 2001.

TRAM, U.; FERREE, P.M.; SULLIVAN, W. Identification of Wolbachia-host interacting factors through cytological analysis. Microbes and Infection, Amsterdam, v. 5, n. 11, p. 9991011, 2003.

TSAI, J.H.; LIU, Y.H. Biology of Diaphorina citri (Homoptera: Psyllidae) on four host plants. Journal of Economic Entomology, Lanham , v. 93, n. 6, p. 1721-1725, 2000.

TSUCHIDA, T.; KOGA, R.; FUKATSU, T. Host plant specialization governed by facultative symbiont. Science, Washington, v. 303, n. 5666, p. 1989, 2004.

VENETI, Z.; CLARK, M.E.; KARR, T.L.; SAVAKIS, C.; BOURTZIS, K. Heads or tails: host-parasite interactions in the Drosophila-Wolbachia system. Applied and Environmental Microbiology, Washington, v. 70, n. 9, p. 5366- 5372, 2004. 
WILKINSON, T.L.; ISHIKAWA, H. On the functional significance of symbiotic microorganisms in the Homoptera: a comparative study of Acyrthosiphon pisum and Nilaparvata lugens. Physiological Entomology, Malden, v. 26, n. 1, p. 86-93, 2008. 


\title{
4 DENSIDADE DE ENDOSSIMBIONTES DURANTE O DESENVOLVIMENTO BIOLÓGICO DE Diaphorina citri (HEMIPTERA; LIVIIDAE)
}

\section{Resumo}

A densidade da infecção está entre os principais parâmetros para a compreensão dos efeitos biológicos nas interações hospedeiro-endossimbiontes. Diaphorina citri mantém associação mutualista com duas bactérias habitantes do bacterioma, além do parasita intracelular Wolbachia. Neste estudo, a dinâmica da densidade de três endossimbiontes associados ao psílideo dos citros foi determinada durante os diferentes estágios de desenvolvimento do hospedeiro por PCR quantitativo em tempo real. As análises do número de cópias dos genes 16S rRNA dos simbiontes Carsonella e Profftella, e do gene ftsZ de Wolbachia, revelaram o crescimento contínuo da densidade dos simbiontes ao longo do desenvolvimento do hospedeiro. Curvas e taxas de crescimento desses simbiontes, estimadas por meio dos parâmetros da equação de Gompertz, indicaram relação inversamente proporcional entre o grau de especialização do simbionte quanto a associação hospedeira e o tempo para atingir a taxa máxima de crescimento. A densidade de Carsonella foi significativamente menor em comparação àquela de Profftella em todos os estágios analisados, apesar da tendência de aumento paralelo. As taxas de crescimento de Wolbachia foram similares àquelas de Carsonella, mas sua densidade foi inferior durante $\mathrm{o}$ desenvolvimento do hospedeiro. Nos adultos, a densidade dos três simbiontes foi maior nos machos. Entretanto, fêmeas em atividade reprodutiva mantiveram os simbiontes em ritmo de densidade crescente, apesar da incorporação dos mesmos aos oócitos. O aumento da densidade de simbiontes em adultos senescentes contrasta com a tendência de declínio observada em outros sistemas de simbiose.

Palavras-chave: Curva de crescimento; PCR quantitativo; Psilídeo dos citros; Simbionte

\begin{abstract}
The infection density of symbionts is among the major parameters to understand their biological effects in host-endosymbionts interactions. Diaphorina citri harbors two bacteriome-associated bacterial endosymbionts, besides the intracellular parasite Wolbachia. In this study, the density dynamics of the three endosymbionts associated with the psyllid $D$. citri was assessed by real-time quantitative PCR (qPCR) at different developmental stages. Bacterial density was assessed by qPCR by the determination of the number of copies of the 16S rRNA gene for Carsonella and Profftella, and of the ftsZ gene for Wolbachia. Analysis revealed a continuous growth in the density of the symbionts during the host development. Symbiont growth and rate curves were estimated by using the parameters of the Gompertz equation, which indicated a negative correlation between the degree of host specialization by the symbiont and the time to achieve the maximum growth rate $\left(\mathrm{t}^{*}\right)$. Carsonella densities were significantly lower than those of Profftella at all host developmental stages analysed, even though they both displayed the same trend. The growth rates of Wolbachia were similar to those of Carsonella, but Wolbachia was not as abundant. Adult males displayed larger symbiont densities than females. However, symbiont density continued to increase in females at their reproductive stage, despite the incorporation of symbionts into the oocytes. The increased density of endosymbionts in senile adults, contrasts with the usual decrease observed during host ageing in other symbiotic systems.
\end{abstract}

Keywords: Asian citrus psyllid; Growth curve; Quantitative PCR; Symbiont 


\subsection{Introdução}

Endossimbiontes são comuns aos insetos e mais de 10\% das espécies dependem da interação com simbiontes mutualistas intracelulares para seu desenvolvimento (DOUGLAS, 1989; BAUMANN, 2005; FELDHAAR; GROSS, 2009). A continuidade da associação de simbiose baseia-se, principalmente, nas inovações metabólicas relacionadas a vantagens ecológicas obtidas pelo hospedeiro, como a suplementação de nutrientes ausentes ou em quantidades inadequadas na dieta, tolerância a fatores de estresse e incremento da capacidade de exploração de plantas hospedeiras por meio de compensação metabólica, entre outros (DOUGLAS, 1989; FELDHAAR, 2011; SACHS; SKOPHAMMER; REGUS, 2011; SLOAN; MORAN, 2012; SU; ZHOU; ZHANG, 2013).

Os simbiontes intracelulares podem ser distinguidos funcional e filogeneticamente como obrigatórios (primários) ou facultativos (secundários), de acordo com o grau de coevolução e codependência, especialização do genoma e localização no organismo hospedeiro (BAUMANN, 2005; SLOAN; MORAN, 2012; WERNEGREEN, 2012). Os simbiontes mutualistas obrigatórios são essenciais ao hospedeiro, com o qual possuem alto grau de coespeciação e dependência, sendo congruentes filogeneticamente e transmitidos à progênie verticalmente, por via transovariana (BAUMANN, 2005; BALMAND et al., 2012; KOGA et al., 2012; SLOAN; MORAN, 2012). No entanto, os simbiontes facultativos, normalmente resultantes de aquisições mais recentes no contexto filogenético, estabelecem interações diversas, podendo contribuir de forma positiva para a nutrição e tolerância a fatores de estresse (BURKE; FIEHN; MORAN, 2010; FELDHAAR, 2011; LUKASIK et al., 2013), mas podem também afetar a aptidão biológica do hospedeiro de várias maneiras. Como exemplo, o simbionte intracelular facultativo Wolbachia, amplamente distribuído entre os insetos, induz uma série de manipulações reprodutivas, tais como feminização, parternogênese, morte de machos e incompatibilidade citoplasmática, resultantes na distorção da razão sexual do hospedeiro (WERREN; BALDO; CLARK, 2008; CORREA; BALLARD, 2012). No entanto, apesar de inúmeros relatos da participação auxiliar desse simbionte em processos de defesa imunológica do hospedeiro (RANCES et al., 2012), na tolerância a fontes de estresse (BIAN et al., 2010), na contribuição nutricional (HOSSOKAWA et al., 2010), na fecundidade do hospedeiro (DEDEINE et al., 2001; 2005), há também inúmeros relatos do custo adaptativo da associação a esse simbionte, que leva à menor longevidade e aptidão reprodutiva (FLEURY et al., 2000; WEEKS; REYNOLDS; HOFFMANN, 2001). 
Os simbiontes primários são abrigados nos bacteriócitos, células especializadas do hospedeiro, comumente organizadas em tecidos complexos, formando o bacterioma. Dependendo da espécie hospedeira, o bacterioma pode abrigar um ou mais simbiontes em zonas específicas, como o citoplasma dos bacteriócitos ou a região sincicial (BUCHNER, 1965; MORAN; TELANG, 1998; BAUMANN, 2005). O bacterioma típico de psilídeos adultos consiste de uma estrutura bilobada, formada por tecido sincicial circundado por bacteriócitos uninucleares arredondados, os quais são revestidos por epitélio delgado (BUCHNER, 1965; BAUMANN, 2005). O citoplasma dos bacteriócitos é preenchido pelo simbionte primário, a bactéria Candidatus Carsonella ruddii, enquanto o citoplasma sincicial é tomado pelo simbionte Candidatus Profftella armatura (WAKU; ENDO, 1987; FUKATSU; NIKOH, 1998; BAUMANN, 2005; NAKABACHI et al., 2013). Adicionalmente, psilídeos podem apresentar o simbionte facultativo Wolbachia (SUBANDIYAH et al., 2000; SAHA et al., 2012).

A manutenção da associação com endossimbiontes ao longo das gerações é garantida pelo método de transmissão transovariana, que envolve a transferência de parte dos simbiontes presentes no bacterioma materno por meio da migração de simbiontes livres ou bacteriócitos intactos para os ovários, onde são depositados durante o ciclo oogênico em etapas que variam de acordo com o hospedeiro (SACCHI et al., 2008; WAKU; ENDO, 1987; ŻELAZOWSKA; BILIŃSKI, 1999; KOGA et al., 2012). Como consequência do processo de transmissão vertical, apenas uma parcela da carga de simbiontes presentes no bacterioma ou bacteriócito materno é transferida aos descendentes (WAKU; ENDO, 1987; MIURA et al., 2003; KOGA et al., 2012). Assim, a população de simbiontes sofre significativa redução, também chamada de efeito gargalo (MIRA; MORAN, 2002; KOGA et al., 2012), no processo de transmissão para a progênie. Dessa forma, a cada gargalo devido aos eventos de transmissão e à ausência de recombinação gênica no ambiente intracelular, acentuam-se os processos de deterioração e especialização genômica do simbionte em sua história evolutiva de associação hospedeira (FUNK; WERNEGREEN; MORAN, 2001; MCCUTCHEON; MORAN, 2012; SLOAN; MORAN, 2012).

A densidade de simbiontes pode ser influenciada por fatores diversos, tais como temperatura (CHEN; LAI; KUO, 2009; CLANCY; HOFFMANN, 1998), idade (BAUMANN; BAUMANN, 1994; HUMPHREYS; DOUGLAS, 1997), sexo (CORREA; BALLARD, 2012), ciclo reprodutivo (WOLSCHIN et al., 2004), polimorfismo (KOMAKI; ISHIKAWA, 2000; NISHIKORI et al., 2009), densidade larval (WIWATANARATANABUTR; KITTAYAPONG, 2009), competição entre simbiontes (GOTO; ANBUTSU; FUKATSU, 
2006), localização e resposta imune do hospedeiro (RATZKA; GROSS; FELDHAAR, 2012, 2013; SU; ZHOU; ZHANG, 2013), o que resulta , direta ou indiretamente, em alterações na aptidão biológica do hospedeiro.

Diaphorina citri mantém associação de mutualismo com bactérias restritas ao bacterioma, os simbiontes Carsonella, residente no citoplasma dos bacteriócitos, e o simbionte Profftella, habitante do citoplasma multinucleado presente no interior do bacterioma (sincício). Adicionalmente, Wolbachia possui distribuição sistêmica, tendo sido observada inclusive no bacterioma. Neste estudo, a densidade desses simbiontes ao longo do desenvolvimento imaturo e adulto de $D$. citri foi avaliada por PCR quantitativo em tempo real (qPCR) por meio da quantificação do número de cópias dos genes 16S rRNA dos simbiontes associados ao bacterioma (Carsonella e Profftella) e do gene ftsZ de Wolbachia.

\subsection{Material e Métodos}

\subsubsection{Criação dos insetos}

Os insetos utilizados nos experimentos foram obtidos de população de Diaphorina citri mantida em condições controladas $\left(28 \pm 2^{\circ} \mathrm{C}, 60 \pm 10 \% \mathrm{UR}\right.$, fotofase $\left.14 \mathrm{~h}\right)$, utilizando-se mudas de murta Murraya exotica (Rutaceae) como substrato de criação (NAVA et al., 2007).

\subsubsection{Método de coleta}

Para verificar a densidade de simbiontes ao longo do ciclo de vida de $D$. citri foram realizadas coletas de ovos, ninfas e adultos, mantidos nas condições de criação descritas (item 4.2.1). A coleta de ovos foi realizada em três intervalos do desenvolvimento embrionário, representando os períodos inicial (ovo-I $=0 \mathrm{~h}-10 \mathrm{~h}$ ), intermediário (ovo-II $=48 \mathrm{~h}-56 \mathrm{~h}$ ) e tardio (ovo-III = 72h-84h). Os cinco ínstares ninfais (N1, N2, N3, N4, N5) foram amostrados no seu primeiro dia de desenvolvimento, ou seja, logo após a eclosão ou logo após a ecdise para os demais ínstares. As coletas durante o estágio adulto (machos e fêmeas) também foram subdivididas em três idades, representando períodos fisiológicos distintos, compreendendo os períodos pré-reprodutivo (0-24 h) (adulto-I), reprodutivo (10 a 25 dias) (adulto-II) e pósreprodutivo (25 a 35 dias) (adulto-III).

Para a coleta de ovos, adultos de $D$. citri, com mais de 5 dias de idade, foram mantidos (proporção 1 q $: 1 \overbrace{}^{\Uparrow})$ em gaiolas de criação $(65 \times 65 \times 40 \mathrm{~cm})$, permitindo-se a oviposição por $4 \mathrm{~h}$, antes de as plantas serem inspecionadas em busca de ovos. Plantas contendo posturas foram 
reservadas para a retirada e fixação dos ovos, de acordo com o estágio embrionário e estádios ninfais de interesse. As amostras coletadas foram mantidas em etanol absoluto a $4^{\circ} \mathrm{C}$ até a extração do DNA genômico.

\subsubsection{Extração do DNA genômico}

A extração de DNA total foi realizada a partir de grupos de insetos, sempre em números idênticos, a fim de evitar variações na eficiência do procedimento de extração. A extração do DNA genômico (gDNA) de ovos, ninfas e adultos de D. citri foi realizada de acordo com Gilbert et al. (2007), a partir de amostras maceradas. As amostras foram maceradas e incubadas em tampão de digestão ( $3 \mathrm{mM} \mathrm{CaCl2;} \%$ SDS; $40 \mathrm{mM}$ dithiotreitol (DTT); $20 \mathrm{mg} / \mathrm{mL}$ proteinase $\mathrm{K} ; 100 \mathrm{mM}$ Tris buffer $\mathrm{pH} \mathrm{8,0;100} \mathrm{mM} \mathrm{NaCl}$ ) em tubos de polipropileno de 1,5 mL de capacidade durante $20 \mathrm{~h}$. Em seguida, foi adicionado o mesmo volume de fenol $(\mathrm{pH} 7,8)$ ao tubo, procedendo-se à agitação e centrifugação das amostras para a separação da fase aquosa, que continha o gDNA, da orgânica. O mesmo procedimento foi repetido substituindo-se o fenol por volume equivalente de clorofórmio. O gDNA recuperado foi precipitado em mistura de isopropanol ( 0,7 vol.): acetato de sódio ( 0,1 vol.): glicogênio $(0,001 \mathrm{vol})$, durante $30 \mathrm{~min}$ a $-80^{\circ} \mathrm{C}$, antes das etapas de centrifugação e lavagem em etanol 85\%. A secagem das amostras (pellet de gDNA) foi realizada em equipamento SpeedVac durante 15 min para posterior ressuspensão em tampão TE (10 mM Tris pH8,0; 1 mM EDTA) por 30 min a $37^{\circ} \mathrm{C}$. O gDNA obtido foi quantificado em espectrofotômetro Nanodrop 2000/2001 (Thermo Scientific) e a qualidade determinada a partir dos valores obtidos para as razões 260/280 e 260/230 e análise em eletroforese em gel de agarose a 0,8\% acrescido de 0,5 $\mu \mathrm{g} / \mathrm{mL}$ de brometo de etídio, em em solução tampão tris-acetato-EDTA (TAE) (40 mM Trisacetato; 1 mM EDTA, pH 7,2) em voltagem constante de $100 \mathrm{~V}$ e posterior visualização em transiluminador. As amostras com qualidade comprovada foram utilizadas nas reações de PCR subsequentes, utilizando-se de iniciadores específicos (item 4.2.4, Tabela 1).

O DNA total extraído de cada triplicata, após quantificação, foi utilizado no cálculo da quantidade equivalente de DNA extraído por indíviduo (ng/inseto- $\Delta$ eq), para que as determinações do número de cópias de cada simbionte pudessem ser expressas em número equivalente a um indivíduo, independemente da quantidade de gDNA a ser utilizada nas reações quantitativas de PCR em tempo real. 


\subsubsection{Desenho dos iniciadores específicos}

Os iniciadores específicos para cada simbionte foram obtidos por meio do software OligoPerfect ${ }^{\mathrm{TM}} \quad$ Designer (Invitrogen) (http://tools.invitrogen.com/content.cfm? pageID=9716), sendo os parâmetros de qualidade dos iniciadores (dimerização, hairpin, temperatura de desnaturação) verificados com o aplicativo online OligoCalc (http:// www.basic.northwestern.edu/biotools/oligocalc.html), tendo como alvo sequências dos genes do 16S rRNA, para os simbiontes do bacterioma, Carsonella (MEYER; HOY, 2008) e Profftella (SALVADOR; CÔNSOLI, dados não-publicados), e do ftsZ para Wolbachia (GUIDOLIN; CÔNSOLI, 2013) (Tabela 1).

Tabela 1 - Iniciadores específicos para as reações de PCR quantitativo em tempo real utilizadas na quantificação dos simbiontes associados à Diaphorina citri

\begin{tabular}{|c|c|c|c|}
\hline Simbionte & Gene & Iniciadores & $\begin{array}{c}\mathrm{N}^{\mathrm{o}} \mathrm{de} \\
\text { Acesso }\end{array}$ \\
\hline Carsonella $(m y c)$ & 16S rRNA & $\begin{array}{l}\text { Myc-F (5'-TGGGAACGCCATATGCTAAT-3') } \\
\text { Myc-R (5'-GTCCCAATGGGTTGTTCATC-3') }\end{array}$ & $\begin{array}{l}\text { GenBank: } \\
\text { EF450250 }\end{array}$ \\
\hline Profftella (syn) & 16S rRNA & $\begin{array}{l}\text { Syn-F (5'-GCCTTTATGGGTAGGGCTTC-3') } \\
\text { Syn-R (5'-CCGGACTACGATGCACTTTT-3') }\end{array}$ & $\begin{array}{l}\text { GenBank: } \\
\text { EU570830 }\end{array}$ \\
\hline Wolbachia (ftsZ) & ftsZ-81 & $\begin{array}{l}\text { ftsZ-F (5'-AGCAGCCAGAGAAGCAAGAG-3') } \\
\text { ftsZ-R (5'-TACGTCGCACACCTTCAAAA-3') }\end{array}$ & $\begin{array}{l}\text { pubMLST: } \\
\text { ST } 173\end{array}$ \\
\hline
\end{tabular}

\subsubsection{Clonagem, curva padrão e condições das reações de PCR quantitativo em tempo real}

Os fragmentos amplificados por cada conjunto de iniciadores foram purificados e inseridos em plasmídeo vetor disponível no sistema pGEM $^{\circledR}-\mathrm{T}$ Easy Vector System (Promega) e utilizados na transformação de células competentes de alta eficiência OneShot ${ }^{\circledR}$ TOP10 (Invitrogen) para a multiplicação dos plasmídeos, seguindo as recomendações do fabricante. Os transformantes foram selecionados em meio de cultura LB acrescido de 100 $\mu \mathrm{g} / \mathrm{mL}$ de ampicilina, tendo 5-bromo-4-cloro-3-indolil- $\beta$-D-galactopiranosídeo (X-GAL) como substrato para a ação da enzima $\beta$-galactosidase, indicadora de transformação. Colônias positivas foram isoladas, cultivadas em meio LB líquido acrescido de ampicilina $(100 \mu \mathrm{g} / \mathrm{mL})$ e utilizadas para a extração de plasmídeos pelo método de lise alcalina (SAMBROOK; RUSSELL, 2001).

Os plasmídeos extraídos foram utilizados em reações de amplificação dos insertos utilizando os iniciadores específicos para cada gene de interesse, sendo a eficiência da reação 
de amplificação verificada via eletroforese em gel de agarose a 1\%, utilizando procedimento idêntico ao anteriormente descrito. As reações de amplificação foram conduzidas a $95^{\circ} \mathrm{C}$ por 5 $\min (1 \mathrm{ciclo}) ; 95^{\circ} \mathrm{C}$ por $45 \mathrm{~s}, 55^{\circ} \mathrm{C}$ por $30 \mathrm{~s}, 72^{\circ} \mathrm{C}$ por $45 \mathrm{~s}$ (40 ciclos); seguidos de extensão final a $72^{\circ} \mathrm{C}$ por $5 \mathrm{~min}$.

Os plasmídeos contendo insertos do tamanho esperado foram utilizados para a geração de curvas-padrão de diluição para cada produto de amplificação. Para a geração da curva padrão, foram conduzidas reações com uma série de seis diluições do plasmídeo+inserto contendo de $20 \mathrm{ng} / \mu \mathrm{L}$ a $0,0064 \mathrm{ng} / \mu \mathrm{L}$, todas em triplicata, em condições de reação otimizadas para cada conjunto de iniciadores. As reações de PCR quantitativo em tempo real (qPCR) foram realizadas no equipamento StepOne (Applied Biosystems), conforme as condições de reação descritas para os iniciadores DcMycF/DcMycR (Carsonella) e DcftsZF/DcftsZR (Wolbachia) $\left(50^{\circ} \mathrm{C}\right.$ por $2 \mathrm{~min}, 95^{\circ} \mathrm{C}$ por $10 \mathrm{~min}$, e 45 ciclos a $95^{\circ} \mathrm{C}$ por $15 \mathrm{~s}$ e $58^{\circ} \mathrm{C}$ por $30 \mathrm{~s}$, seguidos de curva de dissociação ("melting”) a $95^{\circ} \mathrm{C}$ por $15 \mathrm{~s}, 60^{\circ} \mathrm{C}$ por 1 min e $95^{\circ} \mathrm{C}$ por $15 \mathrm{~s}$ ), e para os iniciadores DcSynF/DcSynR (Profftella) $\left(50^{\circ} \mathrm{C}\right.$ por $2 \mathrm{~min}, 95^{\circ} \mathrm{C}$ por $10 \mathrm{~min}$ e 45 ciclos a $95^{\circ} \mathrm{C}$ por $15 \mathrm{~s}$ e $60^{\circ} \mathrm{C}$ por $15 \mathrm{~s}$, seguidos pelo estágio de curva de dissociação a $95^{\circ} \mathrm{C}$ por $15 \mathrm{~s}, 60^{\circ} \mathrm{C}$ por $1 \min$ e $95^{\circ} \mathrm{C}$ por $15 \mathrm{~s}$ ).

O número de cópias ou moléculas/ $\mu \mathrm{L}$ foi determinado a partir da equação (WHELAN; RUSSELL; WHELAN, 2003):

$$
N=\frac{X g / \mu L D N A}{\text { Tamanho do clone em } p b \times 660} 6,022 \times 10^{23}
$$

Sendo,

$\mathrm{X}=$ quantidade de DNA em $\mathrm{g} / \mu \mathrm{L}$

Clone $=$ plasmídeo + inserto

$660 \mathrm{~g} / \mathrm{mol}=$ peso molecular médio de $1 \mathrm{pb}$ DNA

$6,023 \times 10^{23}=$ número de moléculas em $1 \mathrm{~mol}\left(\mathrm{~N}^{\mathrm{o}}\right.$ de Avogadro)

A quantificação da densidade dos simbiontes foi obtida por comparação com a curva padrão no sistema de qPCR StepOne. As reações foram conduzidas contendo $12,5 \mu \mathrm{L}$ de Maxima SYBR Green/ROX qPCR Master Mix (2X) buffer (Fermentas), 0,9 $\mu \mathrm{L}$ do conjunto de iniciadores (concentração de $10 \mu \mathrm{M}$ ), 60 ng de DNA genômico da amostra (ovos, ninfas e adultos) e $8,7 \mu \mathrm{L}$ de água (nuclease-free), totalizando $25 \mu \mathrm{L}$ de volume final. As reações 
foram conduzidas em três repetições biológicas, com cada repetição biológica sendo analisada em triplicata.

\subsubsection{Análises estatísticas}

Os dados do número de cópias dos genes quantificados por qPCR para cada simbionte, utilizados para se estimar a densidade dos simbiontes ao longo do desenvolvimento de $D$. citri, foram submetidos aos testes de Levene e Cramér-von Mises, para se avaliar, respectivamente, a homocedasticidade e normalidade dos dados. Os dados foram transformados para log natural de cada observação $\ln (\mathrm{x})$ e então submetidos à análise de variância (ANOVA) e posterior comparação de médias pelo teste de Tukey $(\mathrm{P} \leq 0,05)$. As análises foram realizadas utilizando-se do software SAS 9.1 (SAS Institute, Cary, NC).

Adicionalmente, o modelo de crescimento de Gompertz (1825), ajustado aos dados, foi utilizado para a obtenção de curvas de crescimento para cada simbionte a partir do número de cópias obtido previamente por qPCR, durante o tempo médio (cerca de 45 dias) de uma geração (ciclo ovo-adulto) do hospedeiro (NAVA et al., 2007), para a população em estudo. As taxas de crescimento e taxas de crescimento máximo para cada simbionte também foram estimadas a partir da equação de Gompertz (FIALHO, 1999), em função da idade do hospedeiro, conforme abaixo:

$$
N C=P f \times e^{\left(-e\left(\left(\ln \left(-\ln \left(\frac{P i}{P f}\right)\right)\right)-B \times t\right)\right)}
$$

e,

$$
t *=\frac{\left.\left.(-1) \times \ln \left(-\ln \left(\frac{P i}{P f}\right)\right)\right)\right)}{B}
$$

Sendo:

$\mathrm{Nc}=$ densidade do simbionte, estimada a partir do número de cópias;

$\mathrm{Pf}$ = tamanho da população final ou máximo crescimento da população;

$\mathrm{Pi}$ = tamanho da população no início ou condição inicial de crescimento;

$\mathrm{B}=$ taxa de crescimento relativo;

$\mathrm{t}=$ idade do hospedeiro;

$\mathrm{t}^{*}=$ tempo em que a taxa de crescimento é máxima; 
$e=$ número de Euler;

$\ln =\log$ natural.

\subsection{Resultados}

Todos os simbiontes associados a $D$. citri, analisados nesse estudo, apresentaram crescimento acentuado do início do desenvolvimento embrionário ao estágio adulto (Figuras 1-3). De modo geral, apesar da tendência de aumento da densidade dos simbiontes observada durante os estágios iniciais da embriogênese, houve diferença estatística $(p<0,0001)$ apenas entre os períodos inicial (ovo-I) e final (ovo-III), sendo o mesmo comportamento verificado durante o desenvolvimento ninfal (Figura 1).

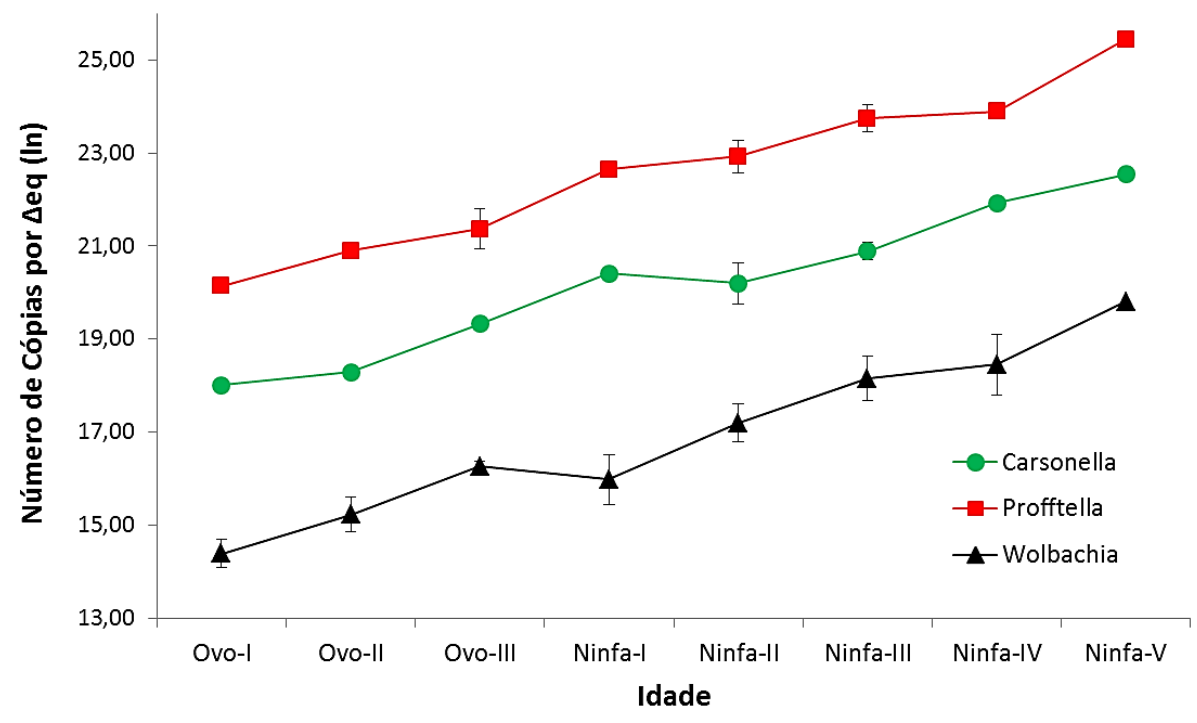

Figura 1 - Média do número de cópias por indivíduo equivalente $(\Delta \mathrm{eq})$ para cada endossimbionte durante o desenvolvimento imaturo de Diaphorina citri. Os valores estão expressos em log natural (ln)

Fêmeas (Figura 2) apresentaram aumento significativo $(\mathrm{p}<0,0001)$ na densidade de Carsonella e de Profftella, comparativamente entre as três idades fisiológicas estudadas, tendo sido verificados valores máximos em fêmeas senescentes, no período pós-reprodutivo (Fêmea-III). Entretanto, os valores observados para Wolbachia no mesmo período não diferiram nos períodos de pré-oviposição e de oviposição (Fêmea-I e II), mas com maior densidade no período pós-reprodutivo (Fêmea-III). Houve diferença significativa na densidade observada para os simbiontes Carsonella $(\mathrm{p}<0,0035)$ e Profftella $(\mathrm{p}<0,0039)$ em 
adultos machos (Figura 3) durante o período pós-reprodutivo (macho-III). Não foram detectadas diferenças na densidade de Wolbachia entre os três períodos fisiológicos em adultos machos ( $>>0,05)$ (Figura 3$)$.

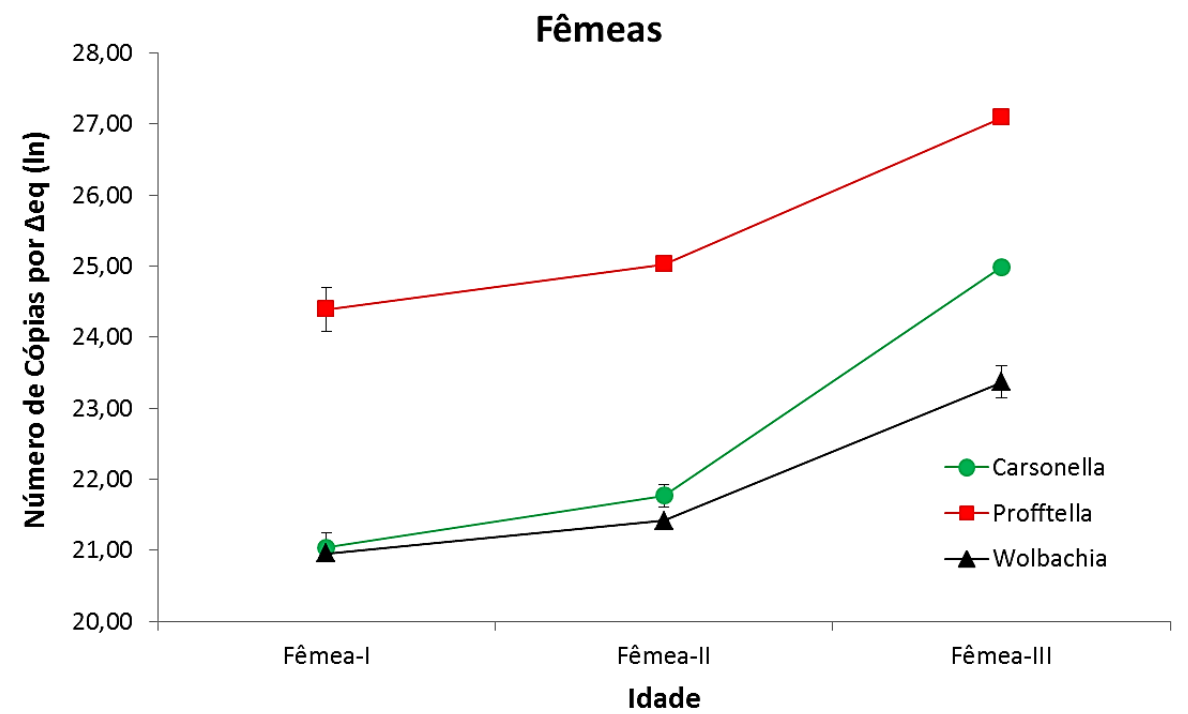

Figura 2 - Média do número de cópias por indivíduo equivalente $(\Delta \mathrm{eq})$ para cada endossimbionte em diferentes idades fisiológicas de fêmeas adultas de Diaphorina citri. Os valores estão expressos em log natural (ln)

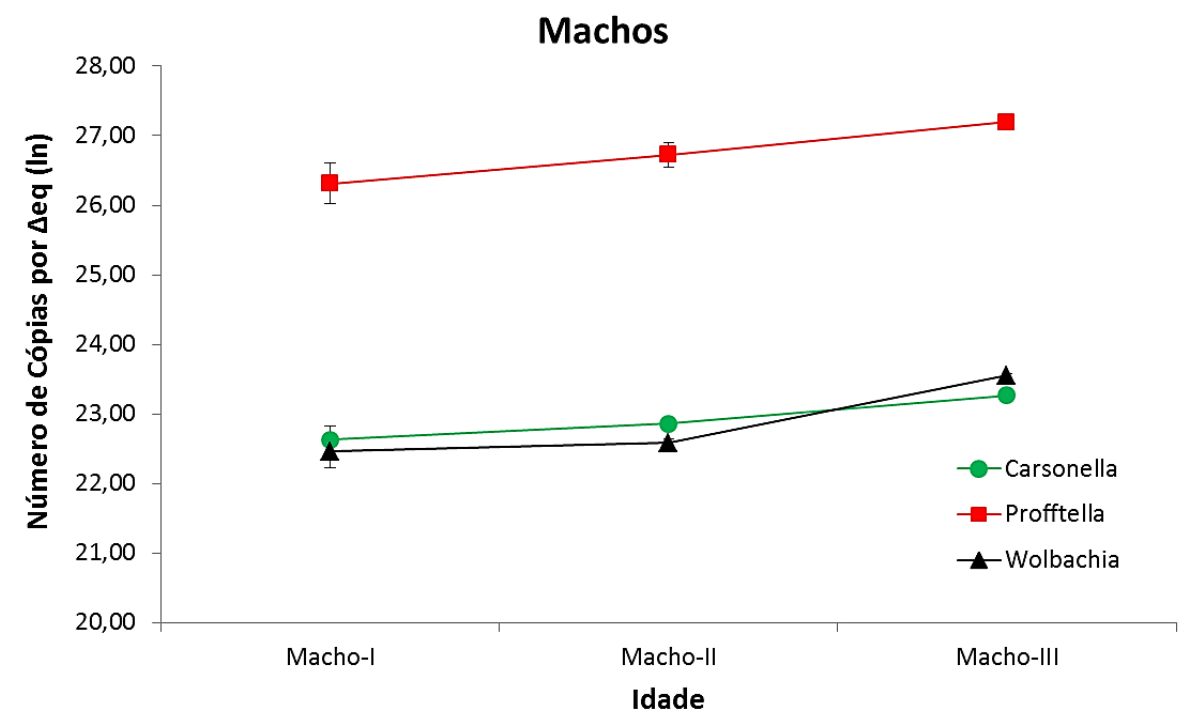

Figura 3 - Média do número de cópias por indivíduo equivalente $(\Delta \mathrm{eq})$ para cada endossimbionte em diferentes idades fisiológicas de machos adultos de Diaphorina citri. Os valores estão expressos em log natural (ln) 
Os valores das estimativas dos parâmetros da equação de Gompertz para a densidade (número de cópias) dos três simbiontes avaliados indicaram o crescimento mais acentuado dos simbiontes nos estágios imaturos de desenvolvimento do hospedeiro, além de diferenças entre fêmeas e machos quanto à densidade inicial $(P i)$ e final $(P f)$ dos simbiontes (Tabela 2), durante o ciclo biológico (45 dias) considerado para D. citri (NAVA et al., 2007). As curvas de crescimento estimadas pelo modelo de Gompertz (Figura 4), a partir da média do número de cópias obtido experimentalmente, indicam taxas diferenciadas de crescimento entre os simbiontes e tempos distintos para que cada um deles atinja a taxa de crescimento máximo $\left(\mathrm{t}^{*}\right)$. O simbionte Wolbachia, por exemplo, atinge a maior taxa de crescimento durante o terceiro ínstar, desacelerando seu crescimento após esse período. O simbionte Profftella possui taxa de crescimento máximo durante o final do estágio imaturo, enquanto Carsonella apresenta sua maior taxa de crescimento durante os períodos reprodutivo (Fêmea-II), nas fêmeas, e pré-reprodutivo (Macho-I), nos machos (Tabela 2 e Figura 4).

Tabela 2 - Estimativas dos parâmetros da equação de Gompertz para o número de cópias por indivíduo equivalente $(\Delta$ eq) para cada endossimbionte ao longo do ciclo biológico de adultos machos e fêmeas de Diaphorina citri

\begin{tabular}{|c|c|c|c|c|c|c|}
\hline \multirow{3}{*}{ Parâmetros } & \multicolumn{6}{|c|}{ Curva de crescimento da média do número de cópias por $\Delta$ eq } \\
\hline & \multicolumn{2}{|c|}{ Carsonella (myc) } & \multicolumn{2}{|c|}{ Profftella (syn) } & \multicolumn{2}{|c|}{ Wolbachia (ftsZ) } \\
\hline & Macho & Fêmea & Macho & Fêmea & Macho & Fêmea \\
\hline Pf & 26,4471 & 24,9259 & 28,0481 & 26,7086 & 23,6752 & 23,4894 \\
\hline $\mathrm{Pi}$ & 17,9479 & 18,2546 & 20,1414 & 20,1984 & 14,0304 & 14,2713 \\
\hline $\mathrm{B}$ & 0,00204 & 0,00196 & 0,00259 & 0,00309 & 0,00303 & 0,00267 \\
\hline $\mathrm{t}^{*}$ & $464 \mathrm{~h}$ & $595 \mathrm{~h}$ & $426 \mathrm{~h}$ & $412 \mathrm{~h}$ & $213 \mathrm{~h}$ & $260 \mathrm{~h}$ \\
\hline Idade ( $\left.\mathrm{t}^{*}\right)$ & Macho-I & Fêmea-II & $N i n f a-V$ & $N i n f a-V$ & Ninfa-III & Ninfa-III \\
\hline
\end{tabular}

Pf = tamanho da população final ou máximo crescimento da população, estimada em log natural (ln) (número de cópias); $\mathrm{Pi}$ = tamanho da população no início ou condição inicial de crescimento, estimada em ln(número de cópias); $\mathrm{B}=$ taxa de crescimento relativa; $\mathrm{t}^{*}=$ tempo em que a taxa de crescimento é máxima (horas). Idade ( $\mathrm{t}^{*}$ ) = estágio do desenvolvimento hospedeiro no qual o t* é atingido. 

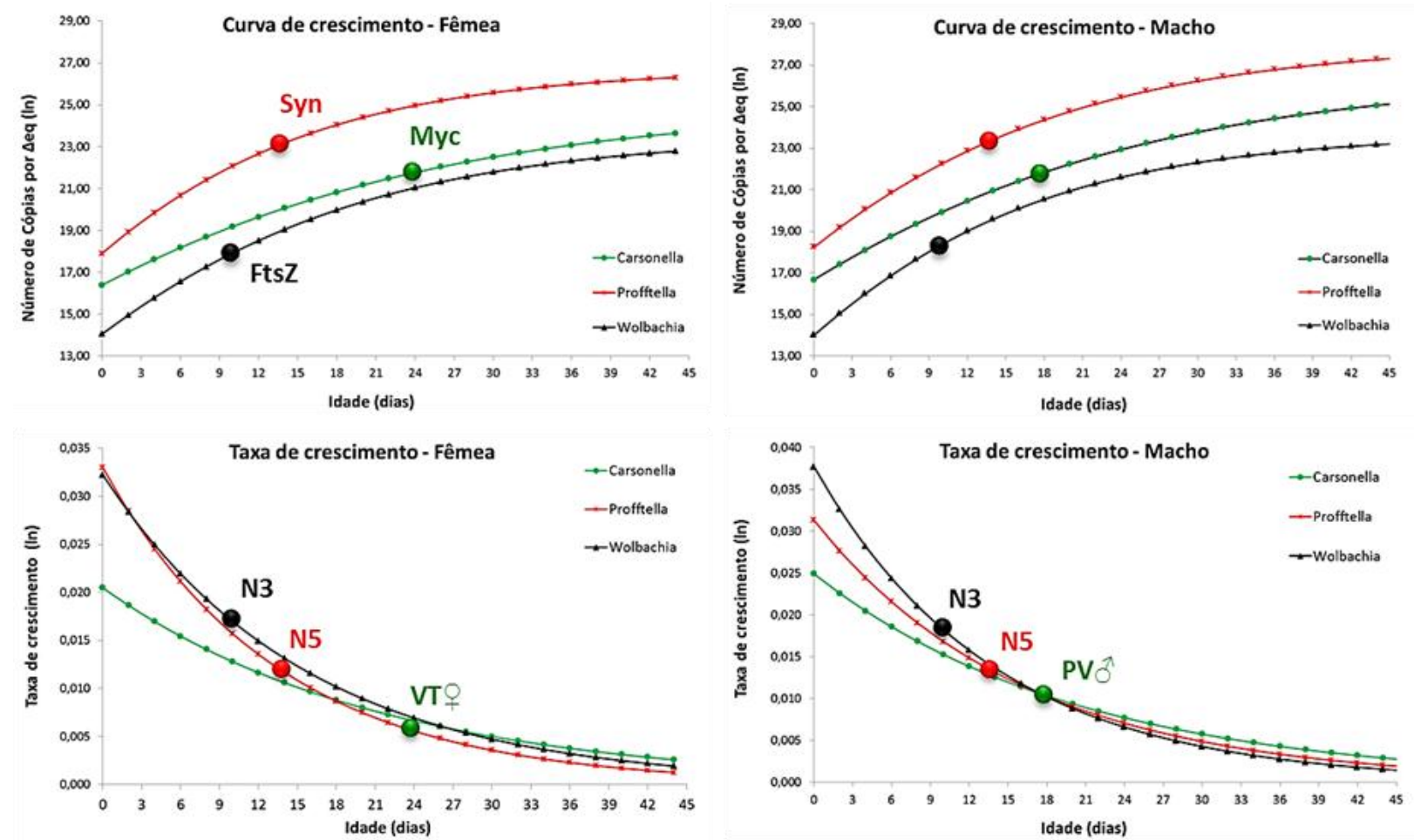

Figura 4 - Curvas (ln número de cópias) (A e B) e taxas (ln número de cópias por hora) (C e D) de crescimento de simbiontes associados a fêmeas (A, C) e machos (B, D) de Diaphorina citri (Hemiptera, Liviidae) durante o ciclo biológico (ovo-adulto), segundo Nava et al. (2007). Os pontos destacados nos gráficos indicam o período do desenvolvimento no qual a taxa de crescimento de cada simbionte é máxima $\left(\mathrm{t}^{*}\right)$. N3 = terceiro ínstar, N5 = quinto ínstar, PVへ̃ = adulto macho préreprodutivo, $\mathrm{VT}+{ }_{+}=$adulto fêmea em idade reprodutiva.

\subsection{Discussão}

A estabilidade da associação em sistemas hospedeiro-simbionte é essencial para o sucesso das funções biológicas. No complexo Diaphorina citri-endossimbiontes, há relação positiva do padrão de crescimento dos simbiontes analisados com o desenvolvimento do hospedeiro, conforme indicam os valores obtidos por qPCR e as estimativas das taxas de crescimento. D. citri possui associação obrigatória com Carsonella e Profftella, além do parasita reprodutivo Wolbachia. Este último, apesar de normalmente estar facultativamente associado a seus hospedeiros, apresenta-se fixado nas populações de D. citri do Brasil (GUIDOLIN; CÔNSOLI, 2013). O crescimento de simbiontes durante o desenvolvimento embrionário de D. citri possui sincronia com os eventos de formação do bacterioma, previamente observados por microscopia (ver detalhes no Capítulo 3, item 3.3), e ocorre de modo lento nos períodos iniciais (ovo-I e II), tornando-se mais intenso no terço final da embriogênese (ovo-III). O incremento significativo na densidade de simbiontes ao final do desenvolvimento embrionário em $D$. citri contrasta com a diminuição da densidade de 
simbiontes relatada para outras espécies, como Periplaneta americana (Blattodea: Blattidae) (SACCHI et al., 1996) e Mastotermes darwiniensis (Isoptera: Mastotermitidae) (SACCHI et al., 1998), nesse mesmo estágio de desenvolvimento, ou em estágios tardios de desenvolvimento do hospedeiro, como em Acyrthosiphon pisum (Hemiptera: Aphididae) (NISHIKORI; KUBO; MORIOKA, 2009) e Camponotus floridanus (Hymenoptera: Formicidae) (RATZKA; GROSS; FELDHAAR, 2013), nos quais parte da população de simbiontes é degradada para atender à demanda nutricional do hospedeiro.

Mudanças adaptativas na regulação da resposta imunológica visando ao gerenciamento da densidade da infecção de simbiontes obrigatórios e facultativos pelo organismo hospedeiro, também podem estar relacionados à flutuação da densidade de simbiontes durante os diferentes estágios de desenvolvimento (NISHIKORI; KUBO; MORIOKA, 2009; DOUGLAS; BOUVAINE; RUSSELL, 2011; RATZKA; GROSS; FELDHAAR, 2012), sendo possível que mecanismos inatos de defesa regulem a infecção, inclusive durante o período embrionário (GORMAN; KANKANALA; KANOST, 2004; FRAUNE; BOSCH, 2010).

Após o desenvolvimento embrionário de $D$. citri, a cinética de crescimento de ambos os simbiontes do bacterioma é contínua com o desenvolvimento do hospedeiro. Esse fato sugere uma provável compensação pelo aumento da demanda metabólica (WAKU; ENDO, 1987), se considerada como verdadeira a participação de Carsonella e de Profftella como parceiros sintróficos e responsáveis pela biossíntese de compostos importantes na nutrição do hospedeiro (WILKINSON; KOGA; FUKATSU, 2007; SLOAN; MORAN, 2012). O crescimento contínuo dos simbiontes do bacterioma de D. citri também pode ser decorrente da provável tolerância/escape dos mesmos à regulação do crescimento bacteriano imposta pelo sistema imunológico do hospedeiro, assim como sugerido para outros complexos simbionte-hospedeiro (RIO et al., 2006; RATZKA; GROSS; FELDHAAR, 2012; LOGIN; HEDDI, 2013).

A similaridade do padrão de crescimento de Wolbachia àquela dos simbiontes do bacterioma de $D$. citri pode ser devido à sua capacidade em manipular a resposta imunológica do hospedeiro, embora os mecanismos relacionados à manipulação da resposta imunológica do hospedeiro pareçam ser altamente específicos das interações Wolbachia-hospedeiro, necessitando ainda de melhor detalhamento (ver revisão de RATZKA; GROSS; FELDHAAR, 2012).

Diversos fatores podem influenciar a flutuação da densidade de simbiontes obrigatórios e facultativos durante o desenvolvimento do hospedeiro, como mecanismos 
decorrentes da restrição de espaço devido às barreiras mecânicas impostas pelo citoesqueleto (LAUDANI et al., 1995; MIURA et al., 2003), localização de simbiontes no interior de células e tecidos especializados (WAKU; ENDO, 1987; MIURA et al., 2003; BAUMANN, 2005; KOGA et al., 2012), degradação de simbiontes em fases específicas do desenvolvimento hospedeiro (DOUGLAS; DIXON, 1987; BAUMANN; BAUMANN, 1994; WILKINSON; KOGA; FUKATSU, 2007), flutuações da densidade de simbiontes em resposta a fatores de estresse e de interações simbionte-simbionte (MONTLLOR et al., 2002; GOTO; ANBUTSU, FUKATSU, 2006; WILKINSON; KOGA; FUKATSU, 2007; BURKE; FIEHN; MORAN, 2010; HERREN; LEMAITRE, 2011), e ainda, regulação pelo sistema imunológico (ver revisão de RATZKA; GROSS; FELDHAAR, 2012). O padrão de crescimento paralelo dos simbiontes em relação ao desenvolvimento de D. citri, aliado ao tempo necessário para que cada um dos simbiontes consiga atingir sua taxa máxima de crescimento $\left(\mathrm{t}^{*}\right)$, sugere a ocorrência de padrões de resposta específicos para cada simbionte, como consequência da história evolutiva das interações simbionte-hospedeiro e simbiontesimbionte nesse sistema. Por exemplo, Carsonella, considerado o simbionte primário de $D$. citri, possui a menor taxa de crescimento em comparação aos demais simbiontes estudados, atingindo sua $t^{*}$ durante o início do estágio adulto em machos e fêmeas. No entanto, o simbionte Profftella, mutualista e obrigatório, considerado uma aquisição mais recente sob o ponto de vista filogenético (SLOAN; MORAN, 2012), apresenta as maiores taxas de crescimento, a qual é máxima durante o quinto instar ninfal. Wolbachia, por sua vez, possui a taxa de crescimento mais acelerada, com a t* durante o terceiro instar ninfal.

Apesar da taxa estimada de crescimento diminuir durante a fase adulta de D. citri, Carsonella e Profftella apresentaram aumento significativo em suas densidades ao longo da vida adulta do hospedeiro. A taxa de crescimento apresentada durante o período reprodutivo foi alta o suficiente para superar a perda de simbiontes pela transferência dos mesmos aos oócitos para a sua transmissão à progênie (Fêmeas-II), já que a densidade de simbiontes foi muito maior do que nas fêmeas pré-reprodutivas (Fêmeas-I). Entretanto, o fato mais surpreendente foi a alta densidade de simbiontes verificada no período pós-reprodutivo (Fêmea-III), tanto de fêmeas como machos, contrastando com o observado em pulgões senescentes (BAUMANN; BAUMANN, 1994; KOMAKI; ISHIKAWA, 2000).

As flutuações na densidade dos simbiontes mutualistas obrigatórios de D. citri sugerem um paralelismo com a demanda metabólica do hospedeiro nas etapas de maturação sexual e produção de ovos, condição similar ao observado durante o período reprodutivo de moscas tsé-tsé Glossina sp. (Diptera: Glossinidae) e às altas densidades do simbionte 
mutualista Wigglesworthia (RIO et al., 2006). A menor densidade de Wolbachia em fêmeas de D. citri durante o período reprodutivo em comparação aos machos, constrasta com o comportamento observado em outras espécies (MOUTON et al., 2004; TORTOSA et al., 2010; CORREA; BALLARD, 2012), e pode ser reflexo da desaceleração da taxa de crescimento após a $\mathrm{t}^{*}$ (terceiro instar) e/ou ao processo de transmissão transovariana. Adicionalmente, fatores relacionados ao custo adaptativo da infecção e a diferenças presumíveis na taxa de proliferação de Wolbachia nos tecidos reprodutivos de machos e fêmeas, precisam de melhor detalhamento (MOUTON et al., 2004; TORTOSA et al., 2010; CORREA; BALLARD, 2012).

A tendência de crescimento dos simbiontes ao longo dos estágios de desenvolvimento de D. citri assemelha-se aos padrões apresentados em outros sistemas de simbiose (BAUMANN; BAUMANN, 1994), exceto durante o período pós-reprodutivo, devido ao aumento da densidade de simbiontes em $D$. citri, o que contrasta com o declínio comumente observado em outros organismos (WOLSCHIN et al., 2004; NISHIKORI et al., 2009). O aumento da densidade de simbiontes durante o período de pós-reprodutivo de $D$. citri pode estar relacionado ao declínio das atividades de reprodução, somado ao suposto comprometimento das atividades de regulação da infecção em decorrência do envelhecimento do hospedeiro (ELEFTHERIANOS; CASTILLO, 2012).

\subsection{Conclusões}

- O crescimento dos simbiontes do bacterioma e de Wolbachia é contínuo ao longo do desenvolvimento de Diaphorina citri;

- As taxas de crescimento estimadas diferem para os simbiontes analisados;

- Wolbachia é o simbionte a atingir taxa de crescimento máximo mais precocemente no desenvolvimento do hospedeiro (terceiro instar);

- Profftella apresenta taxa de crescimento máximo ao término da fase ninfal;

- Carsonella, simbionte primário de D. citri, é o simbionte a atingir a taxa de crescimento máximo mais tardiamente, na fase adulta do hospedeiro;

- Os simbiontes do bacterioma e Wolbachia não sofrem redução no período pósreprodutivo de D. citri; 
- Profftella possui a maior densidade dentre os simbiontes investigados durante todo o desenvolvimento do hospedeiro, enquanto Wolbachia apresenta a menor densidade.

\section{Referências}

BALMAND, S.; LOHS, C.; AKSOY, S.; HEDDI, A. Tissue distribution and transmission routes for the tsetse fly endosymbionts. Journal of Invertebrate Pathology, Sandiego, n.12, p. 116-122, 2012.

BAUMANN, L.; BAUMANN, P. Growth kinetics of the endosymbiont Buchnera aphidicola in the aphid Schizaphis graminum. Applied and Environmental Microbiology, Washington, v. 60, n. 9, p. 3440-3443, 1994.

BAUMANN, P. Biology bacteriocyte-associated endosymbionts of plant sap-sucking insects. Annual Review of Microbiology, Palo Alto, v. 59, p. 155-89, 2005.

BIAN, G.; XU, Y.; LU, P.; XIE, Y.; XI, Z. The Endosymbiotic bacterium Wolbachia induces resistance to dengue virus in Aedes aegypti. PLoS Pathogens, San Francisco, v. 6, n. 4, p. e1000833, 2010.

BUCHNER, P. Endosymbiosis of animals with plant microorganisms. New York: John Wiley, 1965. 909 p.

BURKE, G.; FIEHN, O.; MORAN, N. Effects of facultative symbionts and heat stress on the metabolome of pea aphids. The ISME Journal, New York, v. 4, n. 2, p. 242-252, 2010.

CHEN, C.; LAI, C.; KUO, M. Temperature effect on the growth of Buchnera endosymbiont in Aphis craccivora (Hemiptera: Aphididae). Symbiosis, Dordrecht, v. 49, n. 1, p. 53-59, 2009.

CLANCY, D.J.; HOFFMANN, A.A. Environmental effects on cytoplasmic incompatibility and bacterial load in Wolbachia-infected Drosophila simulans. Entomologia Experimentalis et Applicata, Malden, v. 86, n. 1, p. 13-24, 1998.

CORREA, C.C.; BALLARD, J.W.O. Wolbachia gonadal density in female and male Drosophila vary with laboratory adaptation and respond differently to physiological and environmental challenges. Journal of Invertebrate Pathology, San Diego, v. 111, n. 3, p. 197-204, 2012.

DEDEINE, F.; BOULETREAU, M.; VAVRE, F. Wolbachia requirement for oorgenesis: occurrence within the genus Asobara (Hymenoptera, Braconidae) and evidence for intraspecific variation in A. tabida. Heredity, London, v. 95, n. 5, p. 394-400, 2005.

DEDEINE, F.; VAVRE, FLEURY, F.; LOPPIN, B.; HOCHBERG, M.E.; BOULETREAU, M. Removing symbiotic bacteria Wolbachia specifically inhibits oogenesis in a parasitic wasp. Proceedings of the National Academy of Sciences of the United States of America, Washington, v. 98, n. 11, p. 6247-6252, 2001. 
DOUGLAS, A.E. Mycetocyte symbiosis in insects. Biological Reviews of the Cambridge Philosophical Society, Cambridge, v. 64, n. 4, p. 409-434, 1989.

DOUGLAS, A.E.; BOUVAINE, S.; RUSSELL, R.R. How the insect immune system interacts with an obligate symbiotic bacterium. Proceedings Biological Sciences the Royal Society, London, v. 278, n. 1704, p. 333-338, 2011.

DOUGLAS, A.E.; DIXON, A.F.G. The mycetocyte symbiosis of aphids: variation with age and morph in virginoparae of Megoura viciae and Acyrthosiphon pisum. Journal of Insect Physiology, Oxford, v. 33, n. 2, p. 109-113, 1987.

ELEFTHERIANOS, I.; CASTILLO, J.C. Molecular mechanisms of aging and immune system regulation in Drosophila. International Journal of Molecular Sciences, Basel, v. 13, n. 8, p. 9826-9844, 2012.

FELDHAAR, H.; GROSS, R. Insects as hosts for mutualistic bacteria. International Journal of Medical Microbiology, Jena, v. 299, n. 1, p. 1-8, 2009.

Bacterial symbionts as mediators of ecologically important traits of insect hosts.

Ecological Entomology, Malden, v. 36, n. 5, p. 533-543, 2011.

FIALHO, F.B. Interpretação da curva de crescimento de Gompertz. Concórdia, 1999. Comunicado Técnico. Disponível em:

<http://docsagencia.cnptia.embrapa.br/suino/comtec/cot237.pdf>. Acesso em: 23 out. 2012.

FLEURY, F.; VAVRE, F.; RIS, N.; FOUILLET, P.; BOULETREAU, M. Physiological cost induced by the maternally-transmitted endosymbiont Wolbachia in the Drosophila parasitoid Leptopilina heterotoma. Parasitology, New York, v. 121, n. 5, p. 493-500, 2000.

FRAUNE, S.; BOSCH, T.C.G. Why bacteria matter in animal development and evolution. BioEssays, Malden, v. 32, n. 7, p. 571-580, 2010.

FUKATSU, T.; NIKOH, N. Two intracellular symbiotic bacteria from the mulberry psyllid Anomoneura mori (Insecta, Homoptera). Applied and Environmental Microbiology, Washington, v. 64, n. 10, p. 3599-3606, 1998.

FUNK, D.J.; WERNEGREEN, J.J.; MORAN, N.A. Intraspecific variation in symbiont genomes: bottlenecks and the aphid-Buchnera association. Genetics, Bethesda, v. 157, n. 2, p. 477-489, 2001.

GOMPERTZ, B. On the nature of the function expressive of the law of human mortality and on a new method of determining the value of life contingencies. Transactions of the Royal Philosophical Society of London, London, v. 115, p. 513-585, 1825.

GORMAN, M.J.; KANKANALA, P.; KANOST, M.R. Bacterial challenge stimulates innate immune responses in extra-embryonic tissues of tobacco hornworm eggs. Insect Molecular Biology, Malden, v. 13, n. 1, p. 19-24, 2004. 
GOTO, S.; ANBUTSU, H.; FUKATSU, T. Asymmetrical interactions between Wolbachia and Spiroplasma endosymbionts coexisting in the same insect host. Applied and Environmental Microbiology, Washington, v. 72, n. 7, p. 4805-4810, 2006.

GUIDOLIN, A.S.; CÔNSOLI, F.L. Molecular characterization of Wolbachia strains associated with the invasive Asian citrus psyllid Diaphorina citri in Brazil. Microbial Ecology, New York, v. 65, n. 2, p. 475-486, 2013.

HERREN, J.; LEMAITRE, B. Spiroplasma and host immunity: activation of humoral immune responses increases endosymbiont load and susceptibility to certain Gram-negative bacterial pathogens in Drosophila melanogaster. Cellular Microbiology, Malden, v. 13, n. 9, p. 1385-1396, 2011.

HOSSOKAWA, T.; KOGA, R.; KIKUCHI, Y.; MENG, X.; FUKATSU, T. Wolbachia as a bacteriocyte-associated nutritional mutualist. Proceedings of the National Academy of Sciences of the United States of America, Washington, v. 107, n. 2, p.769-774, 2010.

HUMPHREYS, N.J.; DOUGLAS, A.E. Partitioning of symbiotic bacteria between generations of an insect: a quantitative study of a Buchnera sp. in the pea aphid (Acyrthosiphon pisum) reared at different temperatures. Applied and Environmental Microbiology,Washington, v. 63, n. 8, p. 3294-3296, 1997.

KOGA, R.; MENG, X.Y.; TUSUCHIDA, T.; FUKATSU, T. Cellular mechanism for selective vertical transmission of an obligate insect symbiont at the bacteriocyte-embryo interface. Proceedings of the National Academy of Sciences of the United States of America, Washington, v. 109, n. 20, p. 1230-1237, 2012.

KOMAKI, K.; ISHIKAWA, H. Genomic copy number of intracellular bacterial symbionts of aphids varies in response to developmental stage and morph of their host. Insect

Biochemistry and Molecular Biology, Oxford, v. 30, n. 3, p. 253-258, 2000.

LAUDANI, U.; GRIGOLO, A.; SACCHI, L.; CORONA, S.; BISCALDI, G. On the mycetome formation in Periplaneta americana (Blattaria, Blattidae). Italian Journal of Zoology, Padova, v. 62, n. 4, p. 345-351, 1995.

LOGIN, F.H.; HEDDI, A. Insect immune system maintains long-term resident bacteria through a local response. Journal of Insect Physiology, Oxford, v. 59, n. 2, p. 232-239, 2013.

LUKASIK, P.; DAWID, M.A.; FERRARI, J.; GODFRAY, H.C. The diversity and fitness effects of infection with facultative endosymbionts in the grain aphid, Sitobion avenae.

Oecologia. New York, Epub ahead of print, Apr. 27, 2013. DOI 10.1007/s00442-013-26605.. Disponível em: http://link.springer.com/content/pdf/10.1007\%2Fs00442-013-2660-5.pdf. Acesso em: 30 maio 2013.

MCCUTCHEON, J.P.; MORAN, N.A. Extreme genome reduction in symbiotic bacteria. Nature Reviews Microbiology, London, v. 10, n. 1, p. 13-26, 2012.

MEYER, J.M.; HOY, M.A. Molecular survey of endosymbionts in Florida populations of Diaphorina citri (Hemiptera: Psyllidae) and its parasitoids Tamarixia radiata (Hymenoptera: 
Eulophidae) and Diaphorencyrtus aligarhensis (Hymenoptera: Encyrtidae). Florida Entomologist, Lutz, v. 91, n. 2, p. 294-304, 2008.

MIRA, A; MORAN, N.A. Estimating population size and transmission bottlenecks in maternally transmitted endosymbiotic bacteria. Microbial Ecology, New York, v. 44, n. 2, p. 137-143, 2002.

MIURA, T.; BRAENDLE, C.; SHINGLETON, A.; SISK, G.; KAMBLAMPATI, S.; STERN, D.L. A comparison of parthenogenetic and sexual embryogenesis of the pea aphid Acyrthosiphon pisum (Hemiptera: Aphidoidea). Journal of Experimental Zoology Part B: Molecular and Developmental Evolution, Washington, v. 295, n. 1, p. 59-81, 2003.

MONTLLOR, C.B.; MAXMEN, A.; PURCELL, A.H. Facultative bacterial endosymbionts benefit pea aphids Acyrthosiphon pisum under heat stress. Ecological Entomology, Malden, v. 27, n. 2, p. 189-195, 2002.

MORAN, N.A.; TELANG, A. Bacteriocyte-associated symbionts of insects. BioScience, Washington, v. 48, n. 4, p. 295-304, 1998.

MOUTON, L.; DEDEINE, F.; HENRI, H.; BOULETREAU, M.; PROFIZI, N.; VAVRE, F. Virulence, multiple infections and regulation of symbiotic population in the WolbachiaAsobara tabida symbiosis. Genetics, Bethesda, v. 168, n. 1, p. 181-189, 2004.

NAKABACHI, A.; UEOKA, R.; OSHIMA, K.; TETA, R.; MANGONI, A.; GURGUI, M.; OLDHAM, N.J.; van ECHTEN-DECKERT, G.; OKAMURA, K.; YAMAMOTO, K.; INOUE, H.; OHKUMA, M.; HONGOH, Y.; MIYAGISHIMA, S.; HATTORI, M.; PIEL, J.; FUKATSU, T. Defensive bacteriome symbiont with a drastically reduced genome. Current Biology, Cambridge, v. 23, n. 15, p. 1478-1484, 2013.

NAVA, D.E.; TORRES, M.L.G.; RODRIGUES, M.D.L.; BENTO, J.M.S.; PARRA, J.R.P. Biology of Diaphorina citri (Hem. Psyllidae) on different hosts and at different temperatures. Journal of Applied Entomology, Malden, v. 131, n. 9, p. 709-715, 2007.

NISHIKORI, K.; MORIOKA, K.; KUBO, T.; MORIOKA, M. Age-and morph-dependent activation of the lysosomal system and Buchnera degradation in aphid endosymbiosis. Journal of Insect Physiology, Oxford, v. 55, n. 4, p. 351-357, 2009.

NISHIKORI, K.; KUBO, T.; MORIOKA, M. Morph-dependent expression and subcellular localization of host serine carboxypeptidase in bacteriocytes of the pea aphid associated with degradation of the endosymbiotic bacterium Buchnera. Zoological Science, Tokyo, v. 26, n. 6, p. 415-420, 2009.

OLIVER, K. M.; RUSSEL, J.A.; MORAN, N.A.; HUNTER, M.S. Facultative bacterial symbionts in aphids confer resistance to parasitic wasps. Proceedings of the National Academy of Sciences of the United States of America,Washington, v. 100, n. 4, p. 18031807, 2003.

RANCES, E.; YE, Y.H.; WOOLFIT, M.; MCGRAW, E.A.; O’NEILL, S.L. The relative importance of innate immune priming in Wolbachia-mediated dengue interference. PLoS Pathogens, San Francisco, v. 8, n. 2, p. e1002548, 2012. 
RATZKA, C.; GROSS, R.; FELDHAAR, H. Endosymbiont tolerance and control within insect hosts. Insects, Austin, v. 3, n. 4, p. 553-572, 2012.

RATZKA, C.; GROSS, R.; FELDHAAR, H. Gene expression analysis of the endosymbiontbearing midgut tissue during ontogeny of the carpenter ant Camponotus floridanus. Journal of Insect Physiology, Oxford, v. 59, n. 6, p. 611-623, 2013.

RIO, R.V.M.; WU, Y.N.; FILARDO, G.; AKSOY, S. Dynamics of multiple symbiont density regulation during host development: tsetse fly and its microbial flora. Proceedings Biological Sciences the Royal Society, London, v. 273, n. 1588, p. 805-814, 2006.

SACCHI, L.; CORONA, S.; GRIGOLO, A.; LAUDANI, U.; SELMI, M.G.; BIGLIARD, E. The fate of the endocytobionts of Blattella germanica (Blattaria: Blattellidae) and Periplaneta americana (Blattaria: Blattidae) during embryo development. Italian Journal of Zoology, Padova, v. 63, n. 1, p. 1-11, 1996.

SACCHI, L.; NALEPA, C.A.; BIGLIARDI, E.; LENZ, M.; BANDI, C.; CORONA, S.; GRIGOLO, A.; LAMBIASE, S.; LAUDANI, U. Some aspects of intracellular symbiosis during embryo development of Mastotermes darwiniensis (Isoptera: Mastotermitidae).

Parassitologia, Roma, v. 40, n. 3, p. 309-316, 1998.

SACCHI, L.; GENCHI, M.; CLEMENTI, E.; BIGLIARDI, E.; AVANZATI, A.M.; PAJORO, M.; NEGRI, I.; MARZORATI, M.; GONELLA, E.; ALMA, A.; DAFFONCHIO, D.; BANDI, C. Multiple symbiosis in the leafhopper Scaphoideus titanus (Hemiptera: Cicadellidae): details of transovarial transmission of Cardinium sp. and yeast-like endosymbionts. Tissue \& Cell, Edinburgh, v. 40, n. 4, p. 231-242, 2008.

SACHS, J.L.; SKOPHAMMER, R.G.; REGUS, J.U. Evolutionary transitions in bacterial symbiosis. Proceedings of the National Academy of Sciences of the United States of America, Washington, v. 108, p. 10800-10807, 2011.

SAHA, S.; HUNTER, W.; REESE, J.; MORGAN, J.; HERT, M.; HUANG, H.;

LINDEBERG, M. Survey of endosymbionts in the Diaphorina citri metagenome and assembly of a Wolbachia wDi draft genome. PloS One, San Francisco, v. 7, n. 11, p. e50067, 2012.

SAMBROOK, J.J.; RUSSELL, D.D.W. Molecular cloning: a laboratory manual. New York: Cold Spring Harbor, 2001. 2344p.

SLOAN, D.B.; MORAN, N.A. Genome reduction and co-evolution between the primary and secondary bacterial symbionts of psyllids. Molecular Biology and Evolution, Oxford, v. 29, n. 12 , p. 3781-3792, 2012.

STATISTICAL ANALYSES SYSTEM. SAS/INSIGHT user's guide. versão 9.1.3 - versão para Windows. Cary, 2002/2003. 1 CD-ROM.

SU, Q.; ZHOU, X.; ZHANG, Y. Symbiont-mediated functions in insect hosts.

Communicative \& Integrative, Cambridge, n. 1, p. 1-7, 2013. 
SUBANDIYAH, S.; NIKOH, N.; TSUYUMU, S.; SOMOWIYARJO, S.; FUKATSU, T. Complex endosymbiotic microbiota of the citrus psyllid Diaphorina citri (Homoptera: Psylloidea). Zoological Science, Tokyo, v. 17, n. 7, p. 983-989, 2000.

TORTOSA, P.; CHARLAT, S.; LABBÉ, P.; DEHECQ, J-S.; BARRÉ, H.; WEILL, M. Wolbachia age-sex-specific density in Aedes albopictus: a host evolutionary response to cytoplasmic incompatibility? PLoS ONE, San Francisco, v. 5, n. 3, p. e9700, doi:10.1371/journal.pone.0009700, 2010.

WAKU, Y.; ENDO, Y. Ultrastructure and life cycle of the symbionts in a homopteran insect, Anomoneura mori SCHWARTZ (Psyllidae). Applied Entomology and Zoology, Tokyo, v. 22, n. 4, p. 630-637, 1987.

WEEKS, A.R.; REYNOLDS, K.T.; HOFFMANN, A.A. Wolbachia dynamics and host effects: what has (and has not) benn demonstrated? Trends in Ecology \& Evolution, London, v. 17, n. 6, p. 257-262, 2001.

WERNEGREEN, J.J. Endosymbiosis. Current Biology, Cambridge, v. 22, n. 14, p. R555$561,2012$.

WERREN, J.H.; BALDO, L.; CLARK, M.E. Wolbachia: master manipulators of invertebrate biology. Nature Reviews Microbiology, London, v. 6, n. 10, p. 741-751, 2008.

WHELAN, J.A; RUSSELL, N.B.; WHELAN, M.A.A method for the absolute quantification of cDNA using real-time PCR. Journal of Immunological Methods, London, v. 278, n. 1/2, p. 261-269, 2003.

WILKINSON, T.L.; KOGA, R.; FUKATSU, T. Role of host nutrition in symbiont regulation: impact of dietary nitrogen on proliferation of obligate and facultative bacterial endosymbionts of the pea aphid Acyrthosiphon pisum. Applied and Environmental Microbiology, Washington, v. 73, n. 4, p. 1362-1366, 2007.

WIWATANARATANABUTR, I.; KITTAYAPONG, P. Effects of crowding and temperature on Wolbachia infection density among life cycle stages of Aedes albopictus. Journal of Invertebrate Pathology, Sandiego, v. 102, n. 3, p. 220-224, 2009.

WOLSCHIN, F.; HOLLDOBLER, B.; GROSS, R.; ZIENTZ, E. Replication of the endosymbiotic bacterium Blochmannia floridanus is correlated with the developmental and reproductive stages of its ant host. Applied and Environmental Microbiology, Washington, v. 70, n. 7, p. 4096-4102, 2004.

ŻELAZOWSKA, M.; BILIŃSKI, S. M. Distribution and transmission of endosymbiotic microorganisms in the oocytes of the pig louse, Haematopinus suis (L.) (Insecta: Phthiraptera). Protoplasma, Viena, v. 209, n. 3/4, p. 207-213, 1999. 


\title{
5 CRESCIMENTO DE SIMBIONTES EM Diaphorina citri (HEMIPTERA; LIVIIDAE) EM RESPOSTA AO ESTRESSE TÉRMICO
}

\section{Resumo}

A tolerância de insetos mediada por simbiontes ao choque térmico é um fator ecológico relevante, com implicações sobre a distribuição dos hospedeiros. Diaphorina citri, uma importante praga dos citros em diversos países, mantém associação mutualista com a $\gamma$ Proteobacteria Candidatus Carsonella ruddii e a $\beta$-Proteobacteria Candidatus Profftella armatura, além do simbionte facultativo, a $\alpha$-Proteobacteria Wolbachia. A densidade da infecção do hospedeiro por simbiontes está mutuamente relacionada aos efeitos biológicos, sendo que os simbiontes respondem de formas variáveis ao estresse térmico. Alterações na densidade dos endossimbiontes associados ao psílideo dos citros foram determinadas por PCR quantitativo em tempo real durante o desenvolvimento de ninfas sujeitas ao estresse térmico (choque térmico) na fase de desenvolvimento embrionário. A densidade de cada simbionte foi determinada pela análise do número de cópias dos genes do 16S rRNA para Carsonella e Profftella, e do gene ftsZ para Wolbachia. As análises revelaram diferentes padrões de resposta dos simbiontes em relação às fontes de estresse testadas (temperatura: 32 e $34^{\circ} \mathrm{C}$; tempo de exposição: 3, 6, 12 e 24 h). Temperatura e tempo de exposição afetaram a densidade dos simbiontes estudados de forma distinta, mas a densidade de cada simbionte em resposta ao estresse térmico foi dependente da densidade dos demais simbiontes.

Palavras-chave: Choque térmico; Endossimbiontes; PCR quantitativo; Psilídeo dos citros

\begin{abstract}
The symbiont-mediated insect tolerance to high temperatures is a significant ecological trait with implications on insect distribution. Diaphorina citri, an important citrus pest in several countries, is associated with the mutualistic symbionts Carsonella and Profftella, besides the facultative Wolbachia. The symbiont infection density is related to the intensity of the biological traits they interfere with, but symbionts may respond differently to heat stress. The effects of heat shocks at the host embryonic stage on the growth of the endosymbionts associated with $D$. citri during nymph development was determined by realtime quantitative PCR based on the number of copies of the genes 16S rRNA, for Carsonella and Profftella, and the ftsZ gene, for Wolbachia. Assessment of their copy numbers revealed symbionts differed in their response to the temperature and treatment time used in the heat shock. Symbionts heavily influenced the growth pattern of one and another during nymph development, and the patterns presented by Carsonella and Profftella after heat shock were clearly linked. Wolbachia was the only symbiont to benefit from heat shock treatments, even tough symbiont density fifth instars did not differed from control treatments regardless the symbiont studied, the temperature and time of exposure used. This study demonstrates the influence of heat stress on symbiont density and the need to better understand the biology of insect-symbiont interactions and the dynamics of the relationship with the environment.
\end{abstract}

Keywords: Asian citrus psyllid; Heat shock; Endosymbionts; Quantitative PCR 


\subsection{Introdução}

As interações de simbiose de insetos com micro-organismos e a exploração do potencial metabólico de simbiontes como inovação biológica na conquista de novos nichos, figura entre as principais razões do sucesso evolutivo de insetos (BUCHNER, 1965; SCHOONHOVEN; LOON; DICKE, 2005; FELDHAAR; GROSS, 2009; FELDHAAR, 2011). Durante o processo de coevolução, diversas estratégias foram desenvolvidas por insetos para assegurar a continuidade de suas interações benéficas, como o desenvolvimento de bacteriócitos, estruturas especializadas em abrigar simbiontes, e de mecanismos fisiológicos complexos. Esses mecanismos fisiológicos são voltados à coordenação de eventos metabólicos que envolvem seus simbiontes, como o controle de vias biossintéticas, processos de transmissão vertical de simbiontes e a regulação da resposta imunológica a mutualistas e patógenos. Com esses mecanismos, insetos mantém um amplo leque de interações que compreende simbiontes intra e extracelulares (BAUMANN, 2005; RATZKA et al., 2011; SU; ZHOU; ZHANG, 2013).

Simbiontes intracelulares, os endocitobiontes, podem apresentar relação obrigatória (simbiontes primários ou P-simbiontes) ou facultativa (simbiontes secundários ou $\mathrm{S}$ simbiontes). Endocitobiontes primários são abrigados em bacteriócitos e/ou bacteriomas e são fundamentais à ecologia nutricional de seus hospedeiros, já que fornecem nutrientes essenciais ausentes/limitados na dieta natural do hospedeiro (BAUMANN; MORAN; BAUMANN, 2006; FELDHAAR; GROSS, 2009; FELDHAAR, 2011). Os S-simbiontes apresentam integração metabólica variável com o hospedeiro, podendo ou não contribuir positivamente para o seu desempenho metabólico. A permanência da associação é normalmente obtida pela fixação dos benefícios metabólicos inerentes à interação, ou por meio da manipulação de processos reprodutivos para assegurar a transmissão vertical para a geração seguinte (WERREN; BALDO; CLARK, 2008; FRENTIU et al., 2010; SLOAN; MORAN, 2012).

O desempenho biológico e ecológico de insetos pode ser influenciado por fatores abióticos diversos, sendo o estresse térmico um dos fatores normalmente relatados (FEDER; HOFMANN, 1999; KLOWDEN, 2007). Mas vários taxa de insetos desenvolveram mecanismos sofisticados para o controle da temperatura corporal (CHOWN; NICOLSON, 2004). Adicionalmente, são inúmeros os relatos que demonstram a contribuição de simbiontes para a tolerância de insetos às fontes de estresse, incluindo o térmico (MONTLLOR et al., 2002; RUSSELL; MORAN, 2006; BRUMIN; KONTSEDALOV; GHANIM, 2011). A 
tolerância ao estresse térmico apresentada por insetos associados a simbiontes tem sido conferida à produção constitutiva e/ou induzida de chaperonas pelos simbiontes (MONTLLOR et al., 2002; RUSSELL; MORAN, 2006; MAHADAV et al., 2009; BRUMIN; KONTSEDALOV; GHANIM, 2011), as quais atuam como componentes críticos de mecanismos de proteção celular, altamente complexos e conservados, sendo expressas diferencialmente durante os estágios de desenvolvimento dos insetos (ZHAO; JONES, 2012).

No entanto, o estresse térmico também pode causar efeitos indiretos na interação hospedeiro-simbionte, alterando a densidade de simbiontes no hospedeiro e influenciando a eficiência de transmissão dos mesmos aos descendentes (HUMPHREYS; DOUGLAS, 1997). Adicionalmente, são comuns os relatos da termossensibilidade de simbiontes associados a insetos, sendo a temperatura, inclusive, um dos tratamentos normalmente utilizados na produção de indivíduos apossimbiontes, quando associados a grupos particulares de simbiontes (CHANG, 1974; MONTLLOR et al., 2002; DUNBAR, et al., 2007; BORDENSTEIN; BORDENSTEIN, 2011). A capacidade de indução de fenótipos por Wolbachia, por exemplo, é afetada após a exposição do hospedeiro ao calor (WIWATANARATANABUTR; KITTAYAPONG, 2009; GUO; CONG; WAN, 2012), mas a termossensibilidade desse simbionte parece ser dependente do estágio de desenvolvimento do hospedeiro (BORDENSTEIN; BORDENSTEIN, 2011).

Apesar da amplitude térmica tolerada por Diaphorina citri (NAKATA, 2006; NAVA et al., 2007), o desempenho biológico desse inseto foi prejudicado em temperaturas superiores a $30^{\circ} \mathrm{C}$, com a mortalidade completa das ninfas (NAVA et al., 2007). Assim, dada a natureza mutualista da associação de simbiontes a psilídeos (SLOAN; MORAN, 2012) e à termossensibilidade de simbiontes associados a insetos, esses relatos sugerem que o efeito nocivo da exposição de D. citri a altas temperaturas possa ser decorrente da diminuição/eliminação de simbiontes associados a esse inseto. Dessa forma, este trabalho foi desenvolvido para verificar o efeito do estresse térmico na densidade de endossimbiontes de D. citri, analisando-se a densidade de simbiontes associados ao bacterioma, Candidatus Carsonella ruddi e Candidatus Profftella armatura (NAKABACHI et al., 2013), e de Wolbachia. A densidade desses simbiontes foi determinada via PCR quantitativo em tempo real, durante o desenvolvimento ninfal de $D$. citri, após exposição de ovos pelos períodos de exposição às temperaturas de $32^{\circ} \mathrm{C}$ e $34^{\circ} \mathrm{C}$, consideradas inadequadas ao desenvolvimento normal desse inseto (LIU; TSAI, 2000; NAVA et al., 2007). 


\subsection{Material e Métodos}

\subsubsection{Criação dos insetos}

Os insetos utilizados nos experimentos foram provenientes de população de Diaphorina citri mantida no Laboratório de Interações em Insetos - ESALQ/USP, em condições controladas $\left(28 \pm 2^{\circ} \mathrm{C}, 60 \pm 10 \%\right.$ UR, fotofase $\left.14 \mathrm{~h}\right)$, utilizando-se mudas de murta Murraya exotica (Rutaceae), como substrato de criação (NAVA et al., 2007).

\subsubsection{Coleta de ovos e choque térmico}

Para a obtenção de ovos, adultos de $D$. citri com mais de 5 dias de idade foram mantidos (proporção 1 1 : 1ð) em gaiolas de criação $(65 \times 65 \times 40 \mathrm{~cm})$ para oviposição em plantas de murta (Murraya exotica), por um período de $24 \mathrm{~h}$, em condições controladas $\left(28 \pm 2^{\circ} \mathrm{C}, 60 \% \pm 10 \mathrm{UR}\right.$, fotofase de $\left.14 \mathrm{~h}\right)$. Em seguida, os adultos foram removidos e as plantas, contendo ovos (idade entre 0-24 h), separadas para serem submetidas ao choque térmico.

Para a realização do choque térmico, os ovos foram mantidos nas plantas para se evitar alterações devido ao manuseio, mantendo as condições naturais do local de postura. Dessa forma, as plantas foram acondicionadas em incubadoras mantidas nas temperaturas de $32 \pm 1^{\circ} \mathrm{C}$ ou $34 \pm 1^{\circ} \mathrm{C}(60 \% \pm 10 \mathrm{UR}$, fotofase de $14 \mathrm{~h})$, por períodos de $3,6,12$ ou $24 \mathrm{~h}$ de exposição. Após o tratamento térmico, as plantas foram imediatamente transferidas para sala climatizada $\left(28 \pm 2^{\circ} \mathrm{C}, 60 \% \pm 10 \mathrm{UR}\right.$, fotofase de $\left.14 \mathrm{~h}\right)$, onde permaneceram para a eclosão e desenvolvimento de ninfas.

As plantas foram avaliadas diariamente para monitorar a eclosão ou mudança de ínstar durante o desenvolvimento imaturo. As coletas foram realizadas sempre no primeiro dia após a eclosão ( $1^{\circ}$ ínstar) ou ecdise (demais ínstares). Cinco insetos foram coletados aleatoriamente das plantas em cada período amostral, sendo cada amostra dessas considerada como sendo uma amostra biológica. Cada tratamento contou com três repetições biológicas, sendo cada uma delas analisada em triplicata. As amostras coletadas foram mantidas em etanol a $4^{\circ} \mathrm{C}$ até a extração do DNA genômico. 


\subsubsection{Extração de DNA genômico}

A extração do DNA genômico (gDNA) das ninfas de D. citri foi realizada de acordo com Gilbert et al. (2007). O gDNA obtido foi quantificado em Nanodrop 2000/2001 (Thermo Scientific) e a qualidade determinada a partir dos valores obtidos para as razões 260/280 e 260/230 e análise de integridade do DNA em eletroforese em gel de agarose a 0,8\%, em tampão Tris-acetato-EDTA (TAE) (40 mM Tris-acetato; 1 mM EDTA, pH 7,2), contendo 0,5 $\mu \mathrm{g} / \mathrm{mL}$ de brometo de etídio, e voltagem constante de $100 \mathrm{~V}$, seguido de análise dos fragmentos de DNA em transiluminador UV. As amostras com qualidade comprovada foram utilizadas nas reações de PCR quantitativas subsequentes, utilizando-se iniciadores específicos para os diferentes simbiontes associados a D. citri, os simbiontes do bacterioma, Candidatus Carsonella rudii, Ca. Profftella armatura, e Wolbachia (Tabela 1).

\subsubsection{Iniciadores específicos}

Os iniciadores específicos para cada simbionte foram desenhados por meio do software OligoPerfect ${ }^{\mathrm{TM}}$ Designer (Invitrogen) (http://tools.invitrogen.com/content.cfm? pageID=9716), utilizando-se dos seguintes parâmetros: tamanho do iniciador de 18 a 27 bp, temperatura de desnaturação de 57 a $63^{\circ} \mathrm{C}$, tamanho do produto de amplificação de 100 a 140 bp. Em seguida, os a qualidade dos iniciadores foram verificados usando o aplicativo online OligoCalc (http:// www.basic.northwestern.edu/biotools/oligocalc.html).

As sequências utilizadas como referência para o desenho dos iniciadores estão relacionadas na Tabela 1 .

Tabela 1 - Iniciadores específicos para as reações de PCR quantitativo em tempo real utilizadas na quantificação dos simbiontes associados a Diaphorina citri

\begin{tabular}{|c|c|c|c|}
\hline Simbionte & Gene & Iniciadores & $\begin{array}{l}\mathrm{N}^{\circ} \text { de } \\
\text { Acesso }\end{array}$ \\
\hline Carsonella (myc) & $16 \mathrm{~S}$ rRNA & $\begin{array}{l}\text { Myc-F (5'-TGGGAACGCCATATGCTAAT-3') } \\
\text { Myc-R (5'-GTCCCAATGGGTTGTTCATC-3') }\end{array}$ & $\begin{array}{l}\text { GenBank: } \\
\text { EF450250 }\end{array}$ \\
\hline Profftella (syn) & $16 \mathrm{~S}$ rRNA & $\begin{array}{l}\text { Syn-F (5'-GCCTTTATGGGTAGGGCTTC-3') } \\
\text { Syn-R (5'-CCGGACTACGATGCACTTTT-3') }\end{array}$ & $\begin{array}{l}\text { GenBank: } \\
\text { EU570830 }\end{array}$ \\
\hline Wolbachia (ftsZ) & $f t s Z$ & $\begin{array}{l}\text { ftsZ-F (5'-AGCAGCCAGAGAAGCAAGAG-3') } \\
\text { ftsZ-R (5'-TACGTCGCACACCTTCAAAA-3') }\end{array}$ & $\begin{array}{l}\text { pubMLST: } \\
\text { ST } 173\end{array}$ \\
\hline
\end{tabular}




\subsubsection{Clonagem e otimização das condições de reação de PCR quantitativo}

As reações de PCR conduzidas em termociclador convencional para a obtenção dos produtos de amplificação de cada conjunto de iniciadores específicos foram conduzidas da seguinte forma: $95^{\circ} \mathrm{C}$ por $2 \min \left(1\right.$ ciclo); $95^{\circ} \mathrm{C}$ por $1 \mathrm{~min}, 50^{\circ} \mathrm{C}$ por $1 \mathrm{~min}, 72^{\circ} \mathrm{C}$ por $2 \min (35$ ciclos), seguidos de extensão final a $72^{\circ} \mathrm{C}$ por $5 \mathrm{~min}$. Os fragmentos amplificados por cada conjunto de iniciadores foram purificados pelo método de excesso de sais (SAMBROOK; RUSSEL, 2001) antecedendo ao processo de inserção em plasmídeo vetor disponível no sistema pGEM $^{\circledR}$-T Easy Vector System (Promega), conforme recomendações do fabricante. Os plasmídeos contendo o inserto de interesse foram utilizados na transformação de células competentes de alta eficiência OneShot ${ }^{\circledR}$ TOP10 (Invitrogen) para a multiplicação dos plasmídeos, seguindo as recomendações do fabricante. Os transformantes foram selecionados em meio de cultura LB acrescido de $100 \mu \mathrm{g} / \mathrm{mL}$ de ampicilina, tendo 5-bromo-4-cloro-3indolil- $\beta$-D-galactopiranosídeo (X-GAL) como substrato para a ação da enzima $\beta$ galactosidase, indicadora de transformação. Colônias positivas foram isoladas, cultivadas em meio LB líquido acrescido de ampicilina $(100 \mu \mathrm{g} / \mathrm{mL})$ e utilizadas para a extração de plasmídeos pelo método de lise alcalina (SAMBROOK; RUSSELL, 2001).

Os plasmídeos extraídos foram utilizados para a amplificação de seus insertos utilizando-se de iniciadores específicos para cada gene de interesse, em termociclador programado a $95^{\circ} \mathrm{C}$ por $5 \mathrm{~min}\left(1\right.$ ciclo); $95^{\circ} \mathrm{C}$ por $45 \mathrm{~s}, 55^{\circ} \mathrm{C}$ por $30 \mathrm{~s}, 72^{\circ} \mathrm{C}$ por $45 \mathrm{~s}(40$ ciclos); seguidos de extensão final a $72^{\circ} \mathrm{C}$ por 5 min. Os produtos de amplificação foram resolvidos via eletroforese em gel de agarose a $1 \%$ contendo $0,5 \mu \mathrm{g} / \mathrm{mL}$ brometo de etídio, em tampão 1X Tris-acetato-EDTA (TAE) (40 mM Tris-acetato; $1 \mathrm{mM}$ EDTA, pH 7,2) a temperatura constante de $100 \mathrm{~V}$, seguido de análise em transiluminador UV. Para a confirmação da seleção de plasmídeos contendo insertos do tamanho desejado foi utilizado o marcador $1 \mathrm{~Kb}$ DNA Ladder (Invitrogen). Adicionalmente, os plasmídeos foram linearizados com a utilização de enzima de restrição Sac I (Promega), que promove a clivagem do plasmídeo em apenas um sítio de restrição, para a confirmação do tamanho correspondente (plasmídeo + inserto) por meio de eletroforese em gel de agarose $0,8 \%$, em condições de corrida idênticas às condições citadas anteriormente. Os plasmídeos de especificidade e qualidade confirmados foram utilizados para a geração das curvas padrão de diluição.

Para a geração da curva padrão, foram conduzidas reações com uma série de seis diluições do plasmídeo+inserto contendo de $20 \mathrm{ng} / \mu \mathrm{L}$ a $0,0064 \mathrm{ng} / \mu \mathrm{L}$ em triplicata, em condições de reação otimizadas para cada conjunto de iniciadores. 
As reações de qPCR foram realizadas no equipamento StepOne (Applied Biosystems), utilizando as seguintes condições: para Carsonella (iniciadores DcMycF e DcMycR) e Wolbachia (iniciadores DcftsZF e DcftsZR): $50^{\circ} \mathrm{C}$ por $2 \mathrm{~min}, 95^{\circ} \mathrm{C}$ por $10 \mathrm{~min} \mathrm{e}$ 45 ciclos a $95^{\circ} \mathrm{C}$ por $15 \mathrm{~s}$ e $58^{\circ} \mathrm{C}$ por 30 s, seguidos pelo estágio de desnaturação com $95^{\circ} \mathrm{C}$ por $15 \mathrm{~s}, 58^{\circ} \mathrm{C}$ por 1 min e $95^{\circ} \mathrm{C}$ por $15 \mathrm{~s}$ ), enquanto que para a quantificação do simbionte Profftella (iniciadores DcSynF e DcSynR: $50^{\circ} \mathrm{C}$ por $2 \mathrm{~min}, 95^{\circ} \mathrm{C}$ por $10 \mathrm{~min}$ e 45 ciclos a $95^{\circ} \mathrm{C}$ por $15 \mathrm{~s}$ e $60^{\circ} \mathrm{C}$ por $30 \mathrm{~s}$, seguidos pelo estágio de dissociação com $95^{\circ} \mathrm{C}$ por $15 \mathrm{~s}, 60^{\circ} \mathrm{C}$ por $1 \min$ e $95^{\circ} \mathrm{C}$ por $15 \mathrm{~s}$.

O número de cópias ou moléculas/ $\mu \mathrm{L}$ foi determinado a partir da equação (WHELAN; RUSSELL; WHELAN, 2003):

$$
N=\frac{X g / \mu L D N A}{\text { Tamanho do clone em } p b \times 660} 6,022 \times 10^{23}
$$

Sendo,

$\mathrm{X}=$ quantidade de DNA em $\mathrm{g} / \mu \mathrm{L}$

Clone $=$ plasmídeo + inserto

$660 \mathrm{~g} / \mathrm{mol}=$ peso molecular médio de $1 \mathrm{pb}$ DNA

$6,023 \times 10^{23}=$ número de moléculas em $1 \mathrm{~mol}\left(\mathrm{~N}^{\mathrm{o}}\right.$ de Avogadro $)$

A quantificação da densidade dos simbiontes foi obtida por comparação com a curva padrão no sistema de qPCR StepOne. As reações foram conduzidas contendo $12,5 \mu \mathrm{L}$ de Maxima SYBR Green/ROX qPCR Master Mix (2X) buffer (Fermentas), 0,9 $\mu \mathrm{L}$ de cada iniciador (concentração de $10 \mu \mathrm{M}$ ), 60 ng de DNA genômico da amostra (ovos, ninfas e adultos) e $8,7 \mu \mathrm{L}$ de água (nuclease-free), totalizando $25 \mu \mathrm{L}$ de volume final. As reações foram conduzidas em três repetições biológicas em triplicata para cada estágio avaliado, e o número de cópias foi determinado através das médias. 


\subsubsection{Análises estatísticas}

A densidade dos simbiontes ao longo do desenvolvimento de $D$. citri, foi estimada com base nas médias do número de cópias dos genes quantificados por qPCR. Os dados foram submetidos à análise da homocedasticidade e normalidade, utilizando os testes de Levene e Cramér-von Mises, respectivamente. Para atender as pressuposições para a realização de análise de variância, os dados foram transformados em log natural de cada observação $\ln (\mathrm{x})$. Satisfeito o pressuposto da hipótese de nulidade, os resultados obtidos para cada simbionte (variável dependente) foram submetidos à análise de covariância (ANCOVA) $(\mathrm{p} \leq 0,05)$. Foi avaliada a importância dos efeitos das covariáveis idade do hospedeiro, temperatura, tempo de tratamento, interação temperatura $\mathrm{x}$ tempo, e a influência dos demais simbiontes. As análises foram realizadas no software SAS 9.1 (SAS Institute, Cary, NC).

\subsection{Resultados}

O choque térmico em ovos de Diaphorina citri afetou significativamente $(\mathrm{p}<0,05)$ a densidade dos simbiontes ao longo do desenvolvimento ninfal. A intensidade de resposta de cada simbionte ao estresse térmico foi variável em função dos parâmetros temperatura e tempo de exposição (Tabela 2). Houve tendência de aumento da densidade em relação aos tratamentos de curta duração, mas efeito contrário também foi observado em decorrência de exposições prolongadas às temperaturas testadas, principalmente no intervalo de $24 \mathrm{~h}$ de exposição (Figura 1). Além da influência das temperaturas e tempos de exposição sobre a densidade dos simbiontes durante o desenvolvimento imaturo (Figura 1), foi verificado que a resposta de um simbionte ao tratamento térmico foi influenciada pela densidade dos demais simbiontes (Tabela 2). Apesar da influência de cada simbionte na resposta dos parceiros ao estresse térmico, há diferenças na intensidade dos efeitos (Tabela 2). Os efeitos provocados pelo simbionte Profftella $(\mathrm{p}<0,0001)$ sobre a densidade de Carsonella parecem ser mais expressivos que aqueles induzidos por Wolbachia $(\mathrm{p}<0,0224)$. Apesar da indicação de reciprocidade de efeito entre Carsonella ( $\mathrm{SQR}=9,02161164 ; \mathrm{p}<0,0001)$ e Profftella ( $\mathrm{SQR}=9,11399829 ; \mathrm{p}<0,0001)$, ambos apresentaram maior redução na densidade nos períodos imediatamente posteriores ao choque térmico, enquanto Wolbachia, no mesmo período, apresentou aumento da densidade, mas influenciou Carsonella ( $\mathrm{SQR}=0,62936232 ; \mathrm{p}<0,0224)$ e Profftella (SQR=1,01081670; $\mathrm{p}<0,0001)$ em intensidades diferentes (Tabela 2). A influência 
de Wolbachia sobre Carsonella e Profftella sugere diferenças de intensidade na interação com cada um dos simbiontes mutualistas, e embora o caráter das interações seja desconhecido, se antagonista ou não, os valores sugerem maior intensidade de efeitos de Wolbachia em relação a Profftella (Tabela 2).

Tabela 2 - Análise de covariância das médias do número de cópias por $\Delta$ eq e os efeitos observados na densidade de simbiontes durante o desenvolvimento ninfal de Diaphorina citri

\begin{tabular}{|c|c|c|c|c|c|c|c|c|}
\hline $\begin{array}{l}\text { Variável } \\
\text { dependente }\end{array}$ & Covariáveis & $\begin{array}{l}\text { SQR Tipo } \\
\text { III }\end{array}$ & $\mathbf{F}$ & $\mathbf{P}$ & C.V(\%) & $\mathbf{F}$ & $\mathbf{P}$ & $\mathbf{R}^{2}$ \\
\hline \multirow[t]{6}{*}{$\begin{array}{l}\text { Carsonella } \\
\text { (Myc) }\end{array}$} & Idade & 1,89897508 & 4,03 & 0,0041 & \multirow{6}{*}{1,80} & \multirow{6}{*}{156,33} & \multirow{6}{*}{$<0,0001$} & \multirow{6}{*}{0,948240} \\
\hline & Temperatura & 0,63395912 & 5,39 & 0,0219 & & & & \\
\hline & Tempo & 1,40557712 & 2,99 & 0,0214 & & & & \\
\hline & Syn & 9,11399829 & 77,42 & $<0,0001$ & & & & \\
\hline & Ftsz & 0,62936232 & 5,35 & 0,0224 & & & & \\
\hline & $\begin{array}{c}\text { Temperatura } \\
\text { x Tempo }\end{array}$ & 0,93113255 & 1,98 & 0,1018 & & & & \\
\hline \multirow[t]{6}{*}{$\begin{array}{l}\text { Profftella } \\
\text { (Syn) }\end{array}$} & Idade & 1,99084356 & 4,27 & 0,0028 & \multirow{6}{*}{1,56} & \multirow{6}{*}{159,58} & \multirow{6}{*}{$<0,0001$} & \multirow{6}{*}{0,949241} \\
\hline & Temperatura & 0,05438292 & 0,47 & 0,4957 & & & & \\
\hline & Tempo & 2,16730411 & 4,65 & 0,0015 & & & & \\
\hline & Мyc & 9,02161164 & 77,42 & $<0,0001$ & & & & \\
\hline & FtsZ & 1,01081670 & 8,67 & $<0,0001$ & & & & \\
\hline & $\begin{array}{c}\text { Temperatura } \\
\text { x Tempo }\end{array}$ & 3,95413261 & 8,48 & $<0,0001$ & & & & \\
\hline \multirow[t]{6}{*}{$\begin{array}{l}\text { Wolbachia } \\
\text { (FtsZ) }\end{array}$} & Idade & 18,63207348 & 15,14 & $<0,0001$ & \multirow{6}{*}{3,37} & \multirow{6}{*}{126,83} & \multirow{6}{*}{$<0,0001$} & \multirow{6}{*}{0,936959} \\
\hline & Temperatura & 3,12460843 & 10,15 & 0,0018 & & & & \\
\hline & Tempo & 44,96167590 & 36,53 & $<0,0001$ & & & & \\
\hline & Syn & 1,64530163 & 5,35 & 0,0224 & & & & \\
\hline & Myc & 2,66957429 & 8,67 & 0,0038 & & & & \\
\hline & $\begin{array}{c}\text { Temperatura } \\
\text { x Tempo }\end{array}$ & 5,31444843 & 4,32 & 0,0026 & & & & \\
\hline
\end{tabular}

O efeito do tratamento térmico de ovos de D. citri na densidade de Carsonella pode ser observado logo nos ínstares iniciais, período em que houve maior flutuação da densidade desse simbionte após a exposição de ovos a $32^{\circ} \mathrm{C}$ por períodos de $6 \mathrm{~h}, 12 \mathrm{~h}$ ou $24 \mathrm{~h}$. 
A densidade de Carsonella nos ínstares subsequentes variou em função do período de exposição, com tendência de diminuição nos tratamentos em que os ovos foram expostos a essa temperatura por $24 \mathrm{~h}$, tendo sido observados valores inferiores ao controle. No entanto, independentemente do período de exposição de ovos a $32^{\circ} \mathrm{C}$, a densidade de Carsonella no início do $5^{\circ}$ instar de Diaphorina citri foi semelhante àquela do controle (Figura 1a). Interessantemente, a exposição à temperatura de $34^{\circ} \mathrm{C}$ mostrou-se menos nociva a este simbionte em comparação aos efeitos decorrentes da exposição a $32^{\circ} \mathrm{C}(\mathrm{p}<0,05)$, sendo as exposições mais prolongadas as que mais influenciaram a densidade desse simbionte no hospedeiro (Figura 1b, Tabela 3).

Tabela 3 - Análise de covariância das médias do número de cópias por $\Delta$ eq $( \pm \mathrm{DP})$, relacionadas ao fator tempo de choque térmico e sua influência na densidade de simbiontes associados a Diaphorina citri.

\begin{tabular}{|c|c|c|c|c|c|c|c|}
\hline \multirow[t]{2}{*}{ Simbionte } & \multirow{2}{*}{$\begin{array}{c}\text { Choque } \\
\text { Térmico } \\
\text { (h) }\end{array}$} & \multicolumn{2}{|c|}{ ln do número de cópias/ $\Delta$ eq } & \multirow[t]{2}{*}{$\mathrm{CV}(\%)$} & \multirow[t]{2}{*}{$\mathbf{F}$} & \multirow[t]{2}{*}{$\mathbf{P}$} & \multirow[t]{2}{*}{$\mathbf{R}^{2}$} \\
\hline & & $32^{\circ} \mathrm{C}$ & $34^{\circ} \mathrm{C}$ & & & & \\
\hline \multirow[t]{5}{*}{$\begin{array}{l}\text { Carsonella } \\
(\mathrm{Myc})\end{array}$} & 0 & $19,21 \pm 1,41 \mathrm{aA}$ & $19,21 \pm 1,41 \mathrm{aA}$ & \multirow{5}{*}{1,80} & \multirow{5}{*}{156,33} & \multirow{5}{*}{0,0001} & \multirow{5}{*}{0,948240} \\
\hline & 3 & $18,98 \pm 1,26 a b B$ & $19,55 \pm 1,26 \mathrm{aA}$ & & & & \\
\hline & 6 & $18,95 \pm 1,65 \mathrm{abA}$ & $19,03 \pm 1,64 \mathrm{aA}$ & & & & \\
\hline & 12 & $18,87 \pm 1,93 \mathrm{bA}$ & $18,84 \pm 1,46 \mathrm{bA}$ & & & & \\
\hline & 24 & $18,79 \pm 2,19 \mathrm{bA}$ & $18,82 \pm 1,12 \mathrm{bA}$ & & & & \\
\hline \multirow[t]{5}{*}{$\begin{array}{l}\text { Profftella } \\
\text { (Syn) }\end{array}$} & 0 & $21,75 \pm 1,44 \mathrm{abA}$ & $21,52 \pm 1,44 \mathrm{aA}$ & \multirow{5}{*}{1,56} & \multirow{5}{*}{159,58} & \multirow{5}{*}{0,0001} & \multirow{5}{*}{0,949241} \\
\hline & 3 & $21,96 \pm 1,45 \mathrm{aA}$ & $22,31 \pm 1,45 \mathrm{aA}$ & & & & \\
\hline & 6 & $21,78 \pm 1,77 \mathrm{abA}$ & $21,75 \pm 1,16 \mathrm{aA}$ & & & & \\
\hline & 12 & $21,78 \pm 1,91 \mathrm{abA}$ & $21,56 \pm 1,45 \mathrm{aA}$ & & & & \\
\hline & 24 & $21,53 \pm 1,84 \mathrm{bB}$ & $21,65 \pm 1,51 \mathrm{aA}$ & & & & \\
\hline \multirow[t]{5}{*}{$\begin{array}{l}\text { Wolbachia } \\
\text { (FtsZ) }\end{array}$} & 0 & $15,09 \pm 2,48 \mathrm{cA}$ & $15,09 \pm 2,48 \mathrm{bA}$ & \multirow{5}{*}{3,37} & \multirow{5}{*}{126,83} & \multirow{5}{*}{0,0001} & \multirow{5}{*}{0,936959} \\
\hline & 3 & $16,37 \pm 2,19 \mathrm{bA}$ & $16,74 \pm 1,91 \mathrm{aA}$ & & & & \\
\hline & 6 & $16,40 \pm 2,21 \mathrm{bA}$ & $16,37 \pm 2,69 \mathrm{aA}$ & & & & \\
\hline & 12 & $17,06 \pm 2,45 \mathrm{aA}$ & $16,53 \pm 2,05 \mathrm{aA}$ & & & & \\
\hline & 24 & $17,27 \pm 2,09 \mathrm{aA}$ & $16,50 \pm 1,75 \mathrm{aB}$ & & & & \\
\hline
\end{tabular}

Médias seguidas das mesmas letras minúsculas, na coluna, ou maiúsculas, na linha, não diferem pelo teste de Tukey-Kramer $(p>0,05)$. 
Ainda, Carsonella apresentou maior densidade no início do desenvolvimento de ninfas após exposição a $34^{\circ} \mathrm{C}$ por $3 \mathrm{~h}$, mas a densidade final obtida em ninfas de último ínstar se assemelhou àquela do controle (Figura 1b).

De modo similar ao observado para Carsonella, a densidade de Profftella também foi afetada pela temperatura e tempo de exposição (Figura 1c, d; Tabela 3). Entretanto, não foi verificada diferença $(\mathrm{p}>0,05)$ na densidade média entre as duas temperaturas testadas durante o estágio ninfal (Tabela 3). Os choques térmicos com duração de 6,12 e 24 h a $32^{\circ} \mathrm{C}$ reduziram significativamente a densidade de Profftella no primeiro e segundo ínstares de $D$. citri. Porém, a manutenção do efeito negativo do tratamento térmico ao longo do estágio imaturo sobre a densidade desse simbionte ocorreu apenas no tratamento por $24 \mathrm{~h}$ (Figura 1c). Quando apenas o fator tempo de exposição é considerado, foi possível verificar que o efeito nocivo do choque térmico foi observado nos períodos mais longos de exposição (Tabela 3). Os demais períodos de exposição induziram ao aumento da densidade de Profftella a partir do segundo instar, havendo normalização da densidade durante o quinto instar, exceto para os insetos tratados por $3 \mathrm{~h}$ a $32^{\circ} \mathrm{C}$, cujo aumento foi mantido (Figura 1c). Os efeitos da exposição por $3 \mathrm{~h}$ e $6 \mathrm{~h} \mathrm{a} 34^{\circ} \mathrm{C}$ induziram ao aumento da densidade desse simbionte até o quarto ínstar, havendo tendência de redução da população em relação à maioria dos tratamentos durante o quinto instar (Figura 1d).

Ao contrário dos demais simbiontes, Wolbachia foi o único a apresentar aumento em sua densidade em todos os tratamentos térmicos, do primeiro ao quarto ínstar (Figura 1e, f). sendo a maior densidade atingida na temperatura de $32^{\circ} \mathrm{C}$ (Tabela 3). Esse simbionte apresenta tendência de crescimento acelerado, diferindo dos demais simbiontes avaliados. $\mathrm{O}$ tempo de tratamento foi o fator mais importante (Tabela 1;3) dentre as variâncias testadas $(\mathrm{p}<0,0001)$. Houve crescimento significativo em resposta a todos os tratamentos testados, com tendência de normalização da densidade durante o último ínstar em relação ao controle. Apesar dessa tendência, a densidade foi maior durante o quinto ínstar, nos tratamentos com duração de $12 \mathrm{~h}$ e $24 \mathrm{~h}$ a $32^{\circ} \mathrm{C}$ e $6 \mathrm{~h}$ a $34^{\circ} \mathrm{C}$ (Figura $1 \mathrm{e}, \mathrm{f}$ ). 

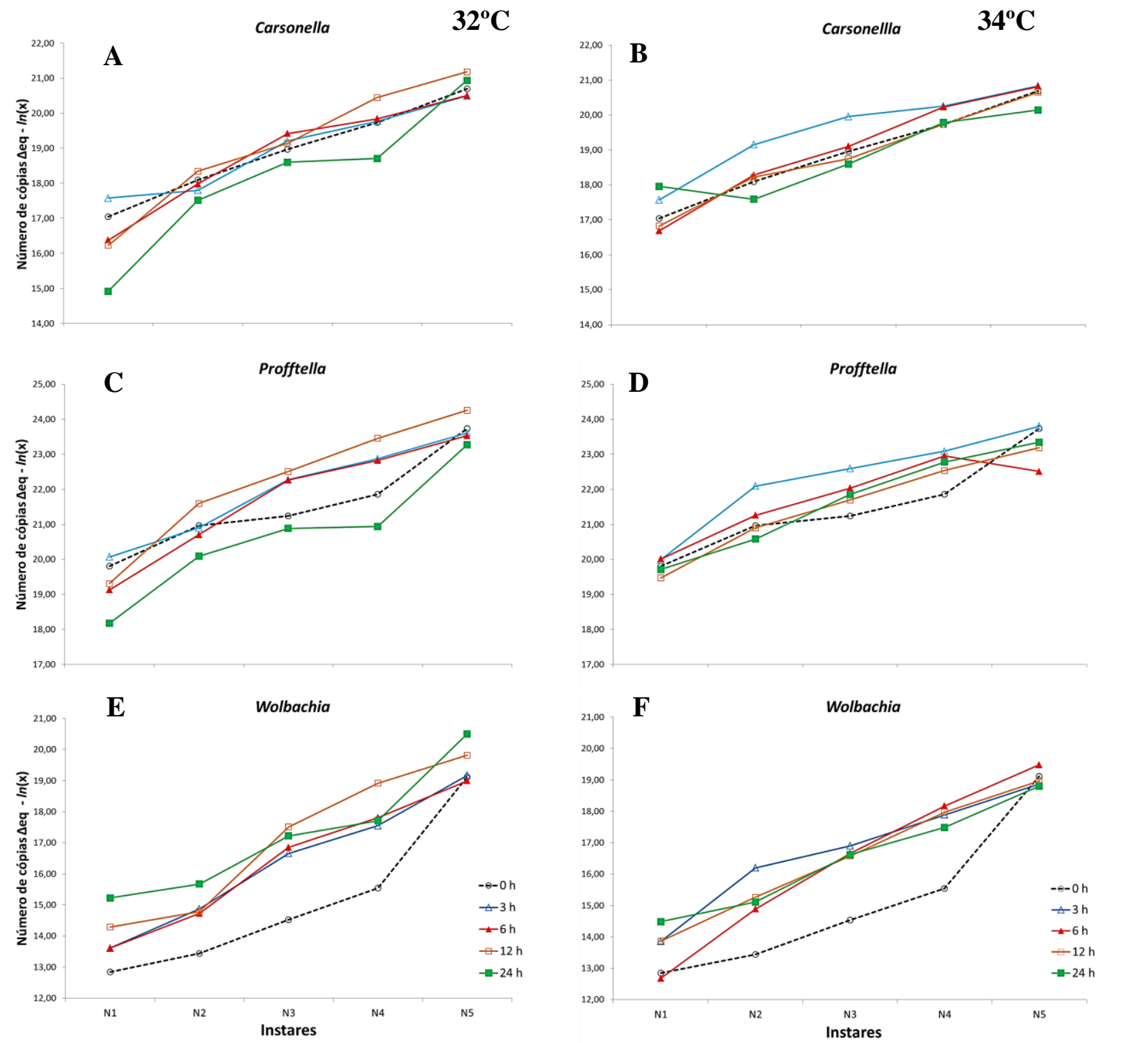

Figura 1 - Densidade de simbiontes durante o desenvolvimento imaturo de Diaphorina citri, após o tratamento térmico dos ovos às temperaturas de $32^{\circ} \mathrm{C}(\mathrm{A}, \mathrm{C}, \mathrm{E})$ e $34^{\circ} \mathrm{C}(\mathrm{B}, \mathrm{D}, \mathrm{F})$ durante diferentes tempos de duração (0h, 3h, 6h, 12h e 24 h). 


\subsection{Discussão}

A exposição de embriões de $D$. citri ao choque térmico por diferentes períodos influenciou diferentemente o crescimento dos simbiontes desse psilídeo durante sua fase ninfal de desenvolvimento. Independentemente da temperatura e tempo de exposição utilizado no tratamento de choque térmico e do efeito induzido no simbionte, se benéfico ou nocivo, todos os simbiontes conseguiram atingir densidades semelhantes àquelas do controle no quinto ínstar.

Fatores ambientais, incluindo a temperatura, podem afetar a densidade dos simbiontes, interferindo no equilíbrio das interações hospedeiro-simbiontes e nos processos fisiológicos relacionados ao desempenho biológico dos insetos. A exposição ao estresse térmico frequentemente resulta na diminuição da densidade ou na eliminação de simbiontes (ANBUTSU; GOTO; FUKATSU, 2008), assim como demonstrado em pulgões (OHTAKA; ISHIKAWA, 1991; BAUMANN; BAUMANN, 1994), moscas-brancas (BRUMIN; KONTSEDALOV; GHANIM, 2011) e percevejos (CHANG, 1974), podendo afetar, consequentemente, o desenvolvimento do hospedeiro. A maioria das informações referentes aos efeitos agudos ou prolongados do choque térmico são referentes ao tratamento de insetos adultos, ou ainda de diferentes fases do desenvolvimento imaturo, quando os insetos ainda podem recorrer à sua mobilidade para buscar novos microambientes e se utilizar de mecanismos fisiológicos envolvidos no controle da termorregulação (HOWE, 1967; FEDER; HOFMANN, 1999; HAMDOUN; EPEL, 2007).

No presente estudo, ovos de Diaphorina citri foram submetidos ao estresse térmico durante o desenvolvimento embrionário inicial (0-24 h de incubação), mas estudos prévios mostram que temperaturas a partir de $32^{\circ} \mathrm{C}$ não são favoráveis ao desenvolvimento imaturo do psilídeo dos citros (NAKATA, 2006; NAVA et al., 2007), embora adultos possam responder a curtos períodos de exposição a temperaturas elevadas (MARUTANI-HERT; HUNTER; HALL, 2010). A redução inicial de apenas cerca de 10 a $14 \%$ nas densidades dos simbiontes que habitam o bacterioma de D. citri, mesmo quando os insetos foram expostos ao choque térmico por $24 \mathrm{~h}$, sugere que o efeito nocivo da temperatura ao desenvolvimento desse psilídeo possa não estar relacionada ao efeito detrimental da temperatura no desenvolvimento de seus simbiontes mutualistas. As reduções observadas nas densidades de Carsonella e de Profftella ao longo do desenvolvimento ninfal foram inferiores àquelas observadas no primeiro estádio, e todos se assemelharam ao controle com o passar do desenvolvimento do inseto. No entanto, o simbionte secundário Wolbachia foi o que mais se beneficiou da 
exposição do hospedeiro ao estresse térmico, mesmo sendo normalmente descrita como uma bactéria termossensível (MOUTON et al. 2006; BORDENSTEIN; BORDENSTEIN, 2011). Wolbachia apresentou densidades de 10 a $18 \%$ superiores àquela do controle no primeiro estádio após o tratamento térmico, e essas diferenças progrediram até o quarto estádio, principalmente a $32^{\circ} \mathrm{C}$. Assim, a maior densidade e o rápido aumento em densidade desse simbionte pode ser um dos fatores a limitar o desenvolvimento do inseto na faixa térmica estudada, tida como inadequada ao seu desenvolvimento, já que existem inúmeros relatos que demonstram os custos adaptativos envolvidos na associação com essa bactéria (WERREN; BALDO; CLARK, 2008; SERBUS et al., 2008).

O aumento na densidade de simbiontes após a exposição ao choque térmico, assim como observado para Carsonella, em resposta ao curto período de estresse, e Wolbachia, contrasta com a diminuição de simbiontes observada em outros sistemas, como a redução da densidade de Buchnera em pulgões expostos ao choque térmico (CHEN; LAI; KUO, 2009; DUNBAR et al., 2007). Essas diferenças talvez possam ser decorrentes do efeito que um simbionte exerce sobre o outro, assim como demonstrado nesse trabalho. A especificidade da regulação entre os simbiontes está relacionada ao tempo da história coevolutiva entre os parceiros (RIO ET AL., 2006). E apesar da falta de informações sobre os aspectos fisiológicos envolvidos na resposta dos simbiontes mutualistas de $D$. citri ao estresse térmico, o alto grau de complementaridade metabólica entre Carsonella e Profftella (SLOAN; MORAN, 2012), pode ser uma das justificativas à reciprocidade e a similaridade dos efeitos do estresse térmico na densidade de ambos. Adicionalmente, o aumento expressivo da densidade de Wolbachia como consequência dos tratamentos térmicos, pode estar relacionado ao efeito significativo apresentado sobre a densidade dos demais simbiontes analisados, assim como observado na interação dessa bactéria com simbiontes em outros sistemas (KONDO; SHIMADA; FUKATSU, 2005; GOTO; ANBUTSU; FUKATSU, 2006), mesmo que a relação de Wolbachia - D. citri - simbiontes do bacterioma seja completamente desconhecida.

É possível que o padrão de resposta dos simbiontes mutualistas de $D$. citri frente ao estresse térmico seja limitado, de modo similar ao verificado em Buchnera, simbionte primário de pulgões (HUMPHREYS; DOUGLAS, 1997). Há, ainda, a possibilidade de que os mesmos tenham sido afetados pelas alterações no ambiente intracelular decorrentes do estresse sofrido pelo hospedeiro, como consequência da dependência funcional de Carsonella em relação ao genoma hospedeiro (NAKABACHI, 2009), embora pouco se saiba sobre a fisiologia de Profftella, a não ser a sua integração funcional a Carsonella (SLOAN; MORAN, 2012). Tal hipótese seria sustentada pela suscetibilidade dos simbiontes mutualistas logo após 
o tratamento térmico, seguido de recuperação paralela ao desenvolvimento do hospedeiro, contrastando com o comportamento de Wolbachia.

Diversos autores relatam a influência dos efeitos do estresse térmico sobre a densidade de infecção de Wolbachia e a diminuição da indução de fenótipos por essa bactéria no hospedeiro (HURST et al., 2000; SARIDAKI; BOURTZIS, 2010; BORDENSTEIN; BORDENSTEIN, 2011). Em Drosophila melanogaster, a curta exposição de ovos ao choque térmico durante a embriogênese inicial parece promover alterações morfofuncionais em Wolbachia, influenciando mecanismos de secreção e interferindo na síntese de proteínas (FEDER et al., 1999; ZHUKOVA; VORONIN; KISELEVA, 2008). Há relatos ainda de que simbiontes possam ser degradados pela atividade lisossomal em bacteriócitos e outros tecidos do hospedeiro, inclusive durante o desenvolvimento embrionário (HINDE, 1971; LAUDANI et al., 1995; SACCHI et al., 1996; NISHIKORI et al., 2009), abrindo a possibilidade de que os produtos dessa degradação possam ser utilizados por simbiontes persistentes e/ou pelo próprio hospedeiro. A possibilidade de utilização desses recursos nutricionais via reaproveitamento, juntamente com a diminuição da competição pela colonização do ambiente intracelular, podem ser fatores que explicariam a maior densidade de Wolbachia em hospedeiros submetidos aos choques térmicos aqui utilizados.

Adicionalmente, os fenótipos reprodutivos induzidos por Wolbachia podem sofrer interferência negativa de proteínas HSP, que atuariam como fatores de atenuação desses efeitos sobre o hospedeiro, concomitantemente aos efeitos do tratamento térmico (FEDER et al. 1999). Embora a expressão de mecanismos celulares de defesa não tenha sido avaliada no presente estudo, a sobrevivência e a manutenção do crescimento acelerado de Wolbachia ao longo do desenvolvimento imaturo podem ser especulados como sendo decorrente (1) da indução de síntese de HSPs, principalmente nos embriões pós-blástula que, assim, teria amenizado os efeitos nocivos do estresse térmico no hospedeiro e simbionte (HAMDOUN; EPEL, 2007; ZHUKOVA; VORONIN; KISELEVA, 2008), e (2) da capacidade de manipulação dos processos de oxidação experimentados pelo hospedeiro após o choque térmico (BRENNAN et al., 2008).

Os valores observados em D. citri indicam maior densidade de Wolbachia à temperatura de $32^{\circ} \mathrm{C}$, mas os tempos de tratamento mostram efeitos variáveis entre os ínstares. De fato, a análise de variância indicou que a duração do choque térmico foi mais significativa sobre Wolbachia que a interação com os demais simbiontes. Apesar da temperatura mais elevada ter afetado a densidade de Wolbachia de forma mais intensa, os tempos empregados podem não ter sido suficientemente restritivos a essa bactéria. 
Os resultados mostram que os simbiontes Carsonella e Profftella são mais suscetíveis ao choque térmico de duração prolongada em comparação a Wolbachia. O choque térmico de curta duração estimulou a proliferação dos simbiontes, apesar da variação de intensidade entre os simbiontes a idade do hospedeiro. Além disso, os simbiontes Carsonella e Profftella, parecem interagir mutuamente em resposta ao estresse térmico. As condições de estresse impostas pelos tratamentos utilizados neste estudo favoreceram o crescimento de Wolbachia, cuja densidade foi superior ao controle em praticamente todos os tempos testados, com exceção do final do estágio imaturo, quando não houve diferença em relação ao controle, para a maioria dos tempos avaliados. A tendência de estabilização da densidade dos simbiontes mutualistas frente aos efeitos do estresse térmico (inferidos na fase de ovo) a partir do terceiro ínstar, sugere a recuperação da homeostase no hospedeiro, fato condizente ao comportamento de recuperação da densidade de simbiontes mutualistas em moscas tsé-tsé, Glossina sp. (RIO et al., 2006). Entretanto, novos estudos devem ser conduzidos para se elucidar os mecanismos celulares afetados pelo choque térmico durante a formação do bacterioma, bem como aqueles relacionados à proteção e recuperação da densidade dos simbiontes durante os períodos iniciais do desenvolvimento imaturo.

\subsection{Conclusões}

- Carsonella, Profftella e Wolbachia respondem diferentemente à exposição do hospedeiro ao estresse térmico na fase de ovo;

- O aumento em densidade de cada simbionte é influenciado pelos demais simbiontes;

- Profftella possui a maior densidade no hospedeiro, seguido por Carsonella e Wolbachia, respectivamente;

- Os tratamentos térmicos de curta duração induziram ao aumento da densidade dos simbiontes, ainda que parcialmente ao longo do estágio ninfal;

- Os simbiontes Carsonella e Profftella são mais suscetíveis ao choque térmico de duração prolongada;

- Wolbachia sofreu aumento da densidade durante todo o desenvolvimento imaturo, com exceção ao último instar, em decorrência dos tratamentos térmicos. 


\section{Referências}

ANBUTSU, H.; GOTO, S.; FUKATSU, T. High and low temperatures differently affect infection density and vertical transmission of male-killing Spiroplasma symbionts in Drosophila hosts. Applied and Environmental Microbiology, Washington, v. 74, n. 19, p. 6053-6059, 2008.

BAUMANN, L.; BAUMANN, P. Growth kinetics of the endosymbiont Buchnera aphidicola in the aphid Schizaphis graminum. Applied and Environmental Microbiology, Washington, v. 60 , n. 9, p. 3440-3443, 1994.

BAUMANN, P. Biology bacteriocyte-associated endosymbionts of plant sap-sucking insects. Annual Review of Microbiology, Palo Alto, v. 59, p. 155-189, 2005.

BAUMANN, P.; MORAN, N.; BAUMANN, L. Bacteriocyte-associated endosymbionts of insects. In: DWORKIN, M.; FALKOW, S.; ROSENBERG, E.; SCHLEIFER, K.; STACKEBRANDT, E. (Ed.). The Prokaryotes. $3^{\text {rd }}$ ed. New York: Springer, 2006. chap. 2.3, p. 403-438.

BORDENSTEIN, S.R. Temperature affects the tripartite interactions between bacteriophage WO, Wolbachia, and cytoplasmic incompatibility. PloS One, San Francisco, v. 6, n. 12, p. e29106, 2011.

BRENNAN, L.J.; KEDDIE, B.A.; BRAIG, H.R.; HARRIS, H.L. The endosymbiont Wolbachia pipientis induces the expression of host antioxidant proteins in an Aedes albopictus cell line. PloS One, San Francisco, v. 3, n. 5, p. e2083, 2008.

BRUMIN, M.; KONTSEDALOV, S.; GHANIM, M. Rickettsia influences thermotolerance in the whitefly Bemisia tabaci B biotype. Insect Science, Malden, v. 18, n. 1, p. 57-66, 2011.

BUCHNER, P. Endosymbiosis of animals with plant microorganisms. New York: John Wiley, 1965. 909p.

CHANG, K.P. Effects of elevated temperature on the mycetome and symbiotes of the bed bug Cimex lectularius (Heteroptera). Journal of Invertebrate Pathology, San Diego, v. 23, n. 3, p. 333-340, 1974.

CHEN, C.; LAI, C.; KUO, M. Temperature effect on the growth of Buchnera endosymbiont in Aphis craccivora (Hemiptera: Aphididae). Symbiosis, Dordrecht, v. 49, n. 1, p. 53-59, 2009.

CHEN, D.Q.; MONTLLOR, C.B.; PURCELL, A.H. Fitness effects of two facultative endosymbiotic bacteria on the pea aphid, Acyrthosiphon pisum, and the blue alfalfa aphid, $A$. kondoi. Entomologia Experimentalis et Applicata, Malden, v. 95, n. 3, p. 315-323, 2000.

CHOWN, S.L.; NICOLSON, S. Insect physiological ecology: mechanisms and patterns. Oxford: Oxford University Press, 2004. 243 p. 
DUNBAR, H.E.; WILSON, A.C.C.; FERGUSON, N.R.; MORAN, N.A. Aphid thermal tolerance is governed by a point mutation in bacterial symbionts. PLoS Biology, San Francisco, v. 5, n. 5, p. e96, 2007.

EBERLEIN, S.; MITCHELL, H.K. Protein synthesis patterns following stage-specific heat shock in early Drosophila embryos. Molecular and General Genetics, Berlin, v. 210, n. 3, p. 407-412, 1987.

FEDER, M.E.; HOFMANN, G.E. Heat-shock proteins, molecular chaperones, and the stress response: evolutionary and ecological physiology. Annual Review of Physiology, Palo Alto, v. 61, p. 243-282, 1999.

FEDER, M.E.; KARR, T.L.; YANG, W.; HOEKSTRA, J.M.; JAMES, A.C. Interaction of Drosophila and its endosymbiont Wolbachia: natural heat shock and the overcoming of sexual incompatibility. Integrative and Comparative Biology, Cary, v. 39, n. 2, p. 363-373, 1999.

FELDHAAR, H. Bacterial symbionts as mediators of ecologically important traits of insect hosts. Ecological Entomology, Malden, v. 36, n. 5, p. 533-543, 2011.

FELDHAAR, H.; GROSS, R. Insects as hosts for mutualistic bacteria. International Journal of Medical Microbiology, Jena, v. 299, n. 1, p. 1-8, 2009.

FRENTIU, F.D.; ROBINSON, J.; YOUNG, P.R.; MCGRAW, E.A.; O'NEILL, S.L. Wolbachia-mediated resistance to dengue virus infection and death at the cellular level. PloS One, San Francisco, v. 5, n. 10, p. e13398, 2010.

GILBERT, M.T.P.; MOORE, W.; MELCHIOR, L.; WOROBEY, M. DNA extraction from dry museum beetles without conferring external morphological damage. PLoS One, San Francisco, v. 2, n. 3, p. e272, 2007.

GRAZIOSI, G.; DE CRISTINI, F.; DI MARCOTULLIO, A.; MARZARI, R.; MICALI, F.; SAVOINI, A.; Morphological and molecular modifications induced by heat shock in Drosophila melanogaster embryos. Journal of Embryology and Experimental Morphology, Cambridge, v. 77, p. 167-182, 1983.

HAMDOUN, A.; EPEL, D. Embryo stability and vulnerability in an always changing world. Proceedings of the National Academy of Sciences of the United States of America, Washington, v. 104, n. 6, p. 1745-1750, 2007.

HOWE, R.W. Temperature effects on embryonic development in insects. Annual Review of Entomology, Palo Alto, v. 12, p. 15-42, 1967.

HUMPHREYS, N.J.; DOUGLAS, A.E. Partitioning of symbiotic bacteria between generations of an insect: a quantitative study of a Buchnera sp. in the pea aphid (Acyrthosiphon pisum) reared at different temperatures. Applied and Environmental Microbiology, Washington, v. 63, n. 8, p. 3294-3296, 1997. 
HURST, G.D.; JOHNSON, A.L.; SCHULENBURG, J.H.G.; FUYAMA, Y. Male-killing Wolbachia in Drosophila: a temperature-sensitive trait with a threshold bacterial density. Genetics, Bethesda, v. 156, n. 2, p. 699-709, 2000.

KLOWDEN, M.J. Physiological systems in insects. $2^{\text {nd }}$ ed. Amsterdam: Elsevier-Academic Press, 2007. 688p.

KREBS, R.A.; FEDER, M.E. Hsp70 and larval thermotolerance in Drosophila melanogaster: how much is enough and when is more too much? Journal of Insect Physiology, Oxford, v. 44, n. 11, p. 1091-1101, 1998.

LIU, Y.H.; TSAI, J.H. Effects of temperature on biology and life table parameters of the Asian citrus psyllid, Diaphorina citri Kuwayama (Homoptera: Psyllidae). Annals of Applied Biology, Malden, v. 137, n. 3, p. 201-206, 2000.

MAHADAV, A.; KONTSEDALOV, S.; CZOSNEK, H.; GHANIM, M. Thermotolerance and gene expression following heat stress in the whitefly Bemisia tabaci B and Q biotypes. Insect Biochemistry and Molecular Biology, Oxford, v. 39, n. 10, p. 668-676, 2009.

MARUTANI-HERT, M.; HUNTER, W.B.; HALL, D.G. Gene response to stress in the Asian citrus psyllid (Hemiptera: Psyllidae). Florida Entomologist, Lutz, v. 93, n. 4, p. 519-525, 2010.

MONTLLOR, C.B.; MAXMEN, A.; PURCELL, A.H. Facultative bacterial endosymbionts benefit pea aphids Acyrthosiphon pisum under heat stress. Ecological Entomology, Malden, v. 27, n. 2, p. 189-195, 2002.

NAKABACHI, A. Mutualism revealed by symbiont genomics and bacteriocyte transcriptomics. In: BOURTZIZ, K.; MULLER, T. (Ed.).Insect Symbiosis. Boca Raton:CRC Press, 2008. $\quad$ v. 3, p. 163-204. http://www.crcnetbase.com/doi/pdf/10.1201/9781420064117.ch8 Acesso em: 28 maio 2013.

NAKABACHI, A.; UEOKA, R.; OSHIMA, K.; TETA, R.; MANGONI, A.; GURGUI, M.; OLDHAM, N.J.; van ECHTEN-DECKERT, G.; OKAMURA, K.; YAMAMOTO, K.; INOUE, H.; OHKUMA, M.; HONGOH, Y.; MIYAGISHIMA, S.; HATTORI, M.; PIEL, J.; FUKATSU, T. Defensive bacteriome symbiont with a drastically reduced genome. Current Biology, Cambridge, v. 23, n. 15, p. 1478-1484, 2013.

NAKATA, T. Temperature-dependent development of the citrus psyllid, Diaphorina citri (Homoptera: Psylloidea), and the predicted limit of its spread based on overwintering in the nymphal stage in temperate regions of Japan. Applied Entomology and Zoology, Tokyo, v. 41, n. 3, p. 383-387, 2006.

NAVA, D.E.; TORRES, M.L.G.; RODRIGUES, M.D.L.; BENTO, J.M.S.; PARRA, J.R.P. Biology of Diaphorina citri (Hem., Psyllidae) on different hosts and at different temperatures. Journal of Applied Entomology, Malden, v. 131, n. 9/10, p. 709-715, 2007.

OHTAKA, C.; ISHIKAWA, H. Effects of heat-treatment on the symbiotic system of an aphid mycetocyte. Symbiosis, Dordrecht, v. 11, n. 1, p. 19-30, 1991. 
OLIVER, K.M.; RUSSELL, J.A.; MORAN, N.A.; HUNTER, M.S. Facultative bacterial symbionts in aphids confer resistance to parasitic wasps. Proceedings of the National Academy of Sciences of the United States of America, Washington, v. 100, n. 4, p. 18031807, 2003.

RATZKA, C.; LIANG, C.; DANDEKAR, T.; GROSS. R.; FELDHAAR, H. Immune response of the ant Camponotus floridanus against pathogens and its obligate mutualistic endosymbiont. Insect Biochemistry and Molecular Biology, Oxford, v. 41, n. 8, p. 529-536, 2011.

RIO, R.V.M.; WU, Y.N.; FILARDO, G.; AKSOY, S. Dynamics of multiple symbiont density regulation during host development: tsetse fly and its microbial flora. Proceedings Biological Sciences the Royal Society, London, v. 273, n. 1588, p. 805-814, 2006.

RUSSELL, J.A; MORAN, N.A. Costs and benefits of symbiont infection in aphids: variation among symbionts and across temperatures. Proceedings of the Royal Society B. Biological Sciences, London, v. 273, n. 1586, p. 603-610, 2006.

SAMBROOK, J.; RUSSELL, D.W. Molecular cloning: a laboratory manual. $3^{\text {rd }}$ ed. New York: Cold Spring Harbor Laboratory Press, 2001. 2344 p.

SARIDAKI, A.; BOURTZIS, K. Wolbachia: more than just a bug in insects genitals. Current Opinion in Microbiology, London, v. 13, n. 1, p. 67-72, 2010.

SCHOONHOVEN, L.M.; LOON, J.J.A.; van DICKE, M. Insect-plant biology. $2^{\text {nd }}$ ed. London: Oxford University Press, 2005. 440p.

SERBUS, L.R.; CASPER-LINDLEY, C.; LANDMAN, F.; SULLIVAN, W. The genetics and cell biology of Wolbachia-host interactions. Annual Review of Genetics, Palo Alto, v. 42, n. 1, p. 683-707, 2008

SLOAN, D.B.; MORAN, N.A. Genome reduction and co-evolution between the primary and secondary bacterial symbionts of psyllids. Molecular Biology and Evolution, Oxford, v. 29, n. 12, p. 3781-3792, 2012.

STATISTICAL ANALYSES SYSTEM. SAS/INSIGHT User's guide. versão 9.1.3 - versão para Windows. Cary, 2002/2003. 1 CD-ROM.

SU, Q.; ZHOU, X.; ZHANG, Y. Symbiont-mediated functions in insect hosts. Communicative and Integrative Biology, Austin, v. 6, n. 3, p. 1-7, 2013.

TSAI, J.H.; LIU, Y.H. Biology of Diaphorina citri (Homoptera: Psyllidae) on four host plants. Journal of Economic Entomology, Lanham, v. 93, n. 6, p. 1721-5, 2000.

WERREN, J.H.; BALDO, L.; CLARK, M.E. Wolbachia: master manipulators of invertebrate biology. Nature Reviews Microbiology, London, v. 6, n. 10, p. 741-51, 2008.

WHELAN, J.A; RUSSELL, N.B.; WHELAN, M.A. A method for the absolute quantification of cDNA using real-time PCR. Journal of Immunological Methods, Amsterdam, v. 278, n. $1 / 2$, p. $261-269,2003$. 
WIWATANARATANABUTR, I.; KITTAYAPONG, P. Effects of crowding and temperature on Wolbachia infection density among life cycle stages of Aedes albopictus. Journal of Invertebrate Pathology, San Diego, v. 102, n. 3, p. 220-224, 2009.

ZHAO, L.; JONES, W. Expression of heat shock protein genes in insect stress responses. Invertebrate Survival Journal, Modena, v. 9, p. 93-101, 2012.

ZHUKOVA, M.V.; VORONIN, D.A.; KISELEVA, E.V. High temperature initiates changes in Wolbachia ultrastructure in ovaries and early embryos of Drosophila melanogaster. Cell and Tissue Biology, Berlin, v. 2, n. 5, p. 546-556, 2008. 